\begin{tabular}{l|l}
$S D$ & UC-NRLF \\
404 & B 3854332 \\
$R_{3}$ & B
\end{tabular}

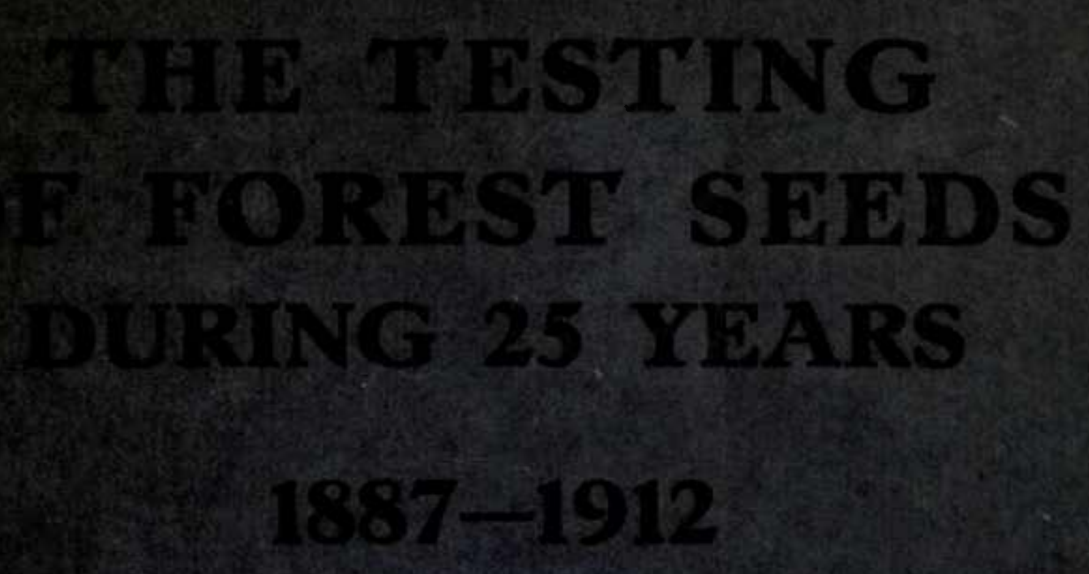



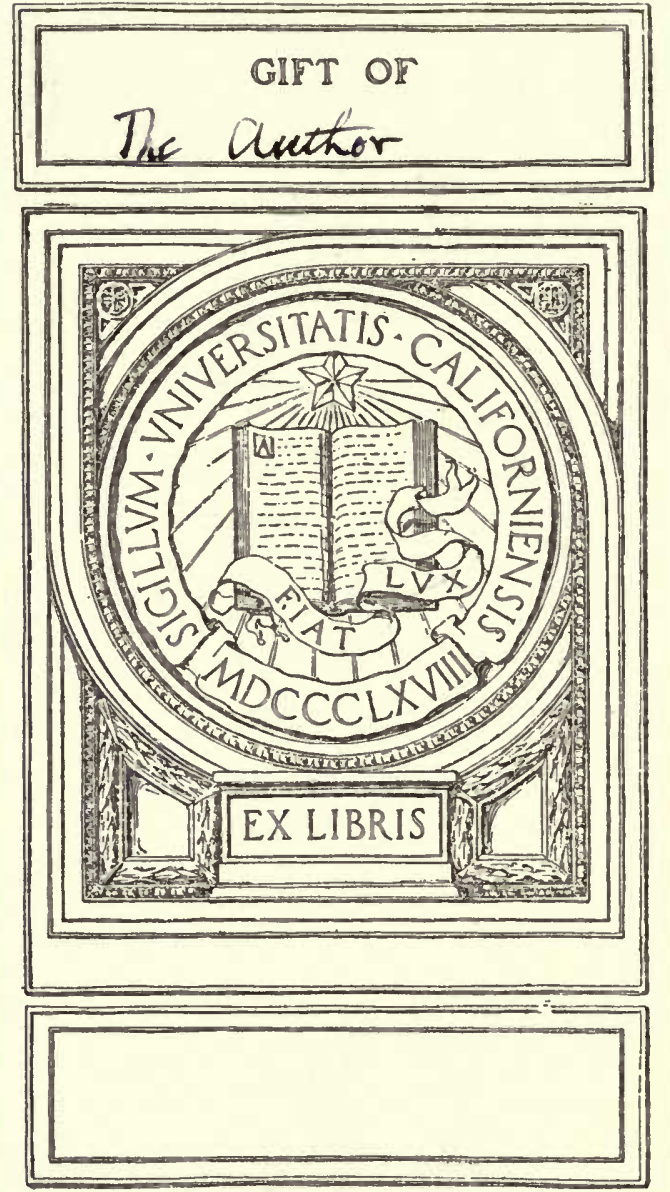




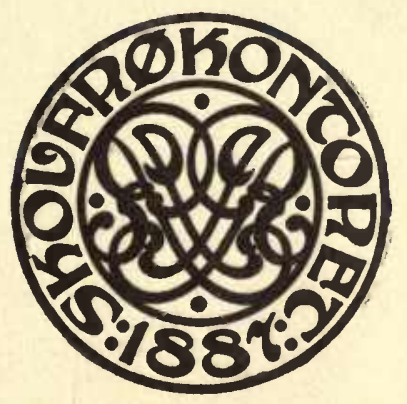




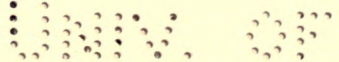

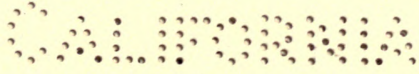




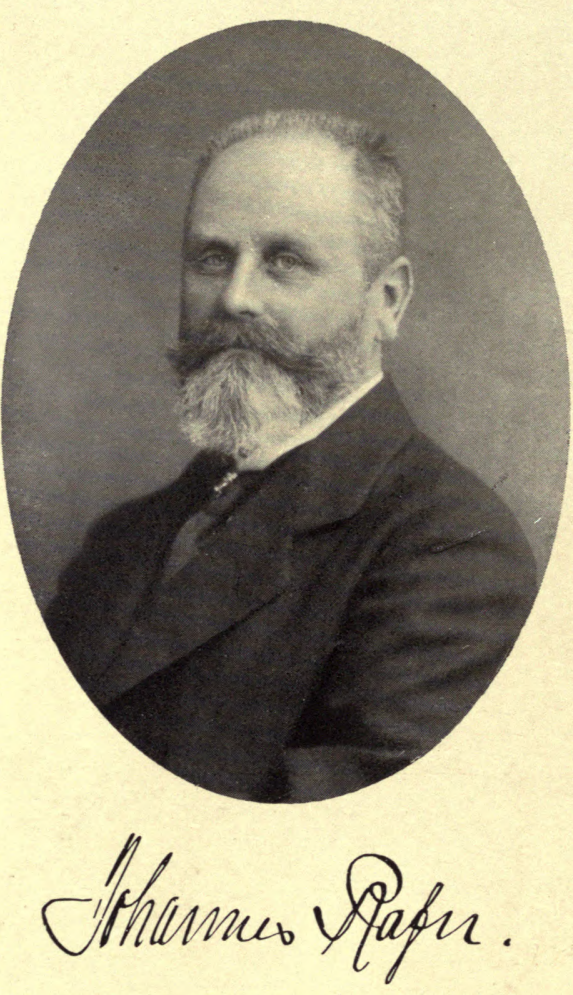

$\because 80$

$\therefore<000$ 


\section{JOHANNES RAFN}

\section{THE TESTING \\ OF FOREST SEEDS \\ DURING 25 YEARS \\ 1887-1912}

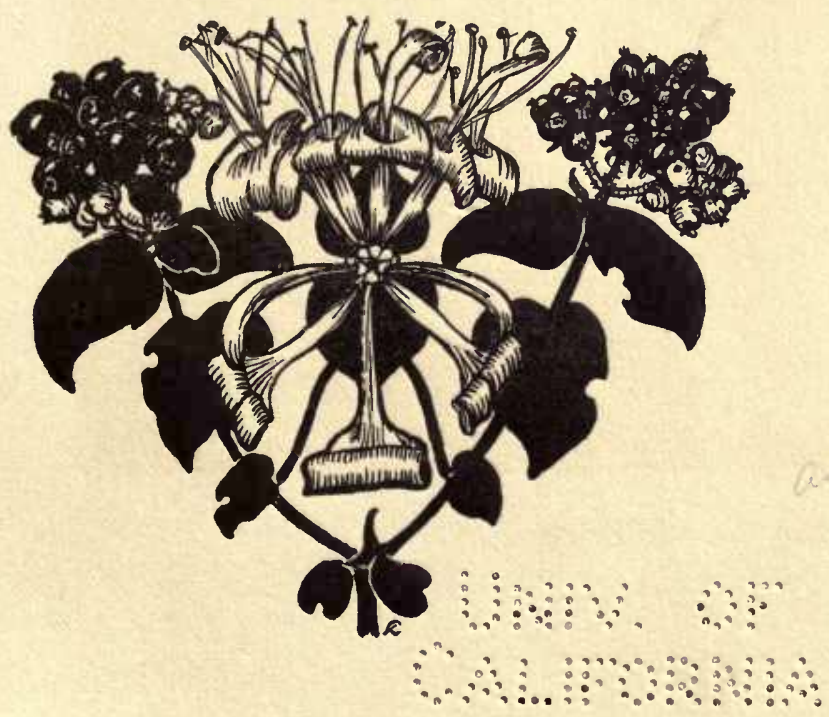

PRINTED FOR PRIVATE CIRCULATION 


$$
\begin{gathered}
\text { giptoz antor } \\
\qquad 11 / 16 / 21
\end{gathered}
$$

$\because \because \quad \because \because 30$

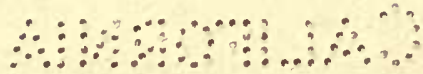



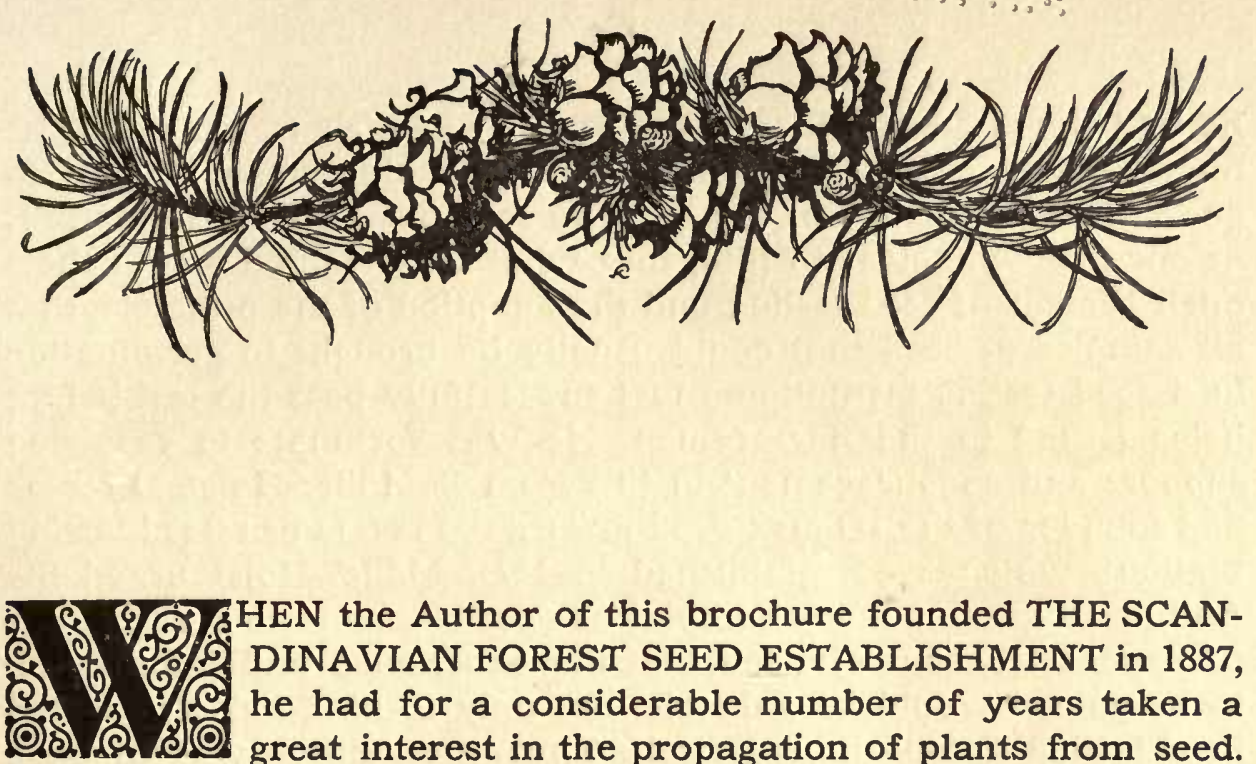

HEN the Author of this brochure founded THE SCANDINAVIAN FOREST SEED ESTABLISHMENT in 1887, he had for a considerable number of years taken a great interest in the propagation of plants from seed. Especially valuable to him was the experience gained between 1874 and 1879, in Nurseries in Danmark, England, France and Germany.

He attaches most importance to the time spent in the nurseries of Orleans; the insight he obtained there into the treatment of the seeds of trees and shrubs has proved invaluable to him in his later researches.

The methods of sowing, and more especially the preparation of the seed before sowing, particularly claimed his attention. When one thinks of the vast extent and importance of the well known forest nurseries round Halstenbek in Holstein, it is interesting to recollect that, when the Author laboured at Orléans thirty-six years ago, these nurseries produced little else but thorn quicks, while the seed beds of Orléans were pre-eminent in every way. It is the methods then used at Orléans - and more particularly the practice of causing the various seeds to germinate before being sown - which with later improvements and suitable modifications, are now used at Halstenbek.

In 1880 the Author established a Forest Nursery at Kolding in Jutland; but unfortunately an infestation of Cockchafer grubs destroyed many hundreds of thousands of one- and two- years old seedlings. This misfortune caused him to turn his attention to what has since become his life-work.

When the Author started as a trader in the seed of forest trees,<smiles>[LiH]</smiles> 


\section{6}

he had thus had considerable experience of their treatment in the nursery; but there was nothing to guide him when he had to guarantee the quality of the seed he sent out to his customers. It at once became clear to him, that what was wanted was a thorough system of seed testing and the adoption of the principle, that all samples of seed that could usually be brought to germination in a seed testing institution, must successfully pass the test before being issued to the nurserymen. He was fortunate in receiving support and encouragement in this from E. Möller-Holst, Director and founder of the "Dansk Frökontrolstation (Danish Seed-testing Station), which was established in 1871. Möller-Holst urged the Author to send as many samples as possible for testing, regardless of expense, because he felt that the experience and information to be gained would be valuable, not only to him, but also to the Seed-testing Establishment itself. Thus the Author was at once placed in a position to obtain an insight into what could be achieved in the realm of forest seed by systematic seed testing.

In the first year a report was issued on 56 tests, which together with an exhibition of tree seeds in the Forestry Section of the Northern Industrial and Agricultural Exhibition in Copenhagen in 1888 , obtained for his firm the only medal awarded to a Forest Seed Establishment. This award has been followed by many others since, both at home and abroad.

In the following year appeared "Analyseresultater fra 1888-89 « (Tree-seed Testing 1888-1889), containing the results of 131 germination and seed weight tests on seeds of many different kinds and many different places of origin.

The Author gratefully remembers the unselfish interest and encouraging influence of $\mathrm{E}$. Möller-Holst, which made it possible for him to obtain so early in his career, such a wide experience and many-sided knowledge of tree seeds. Unhappily Möller-Holst died as early as 1888 and did not live to see the fruits of his labour and the subsequent development of the SCANDINAVIAN FOREST SEED ESTABLISHMENT. After his death the Danish Seedtesting Station became a State institution, which has since grown to such an extent, that in the season 1911-12, for example, it carried out about 12,000 tests on agricultural, garden and forest seeds.

The germinating apparatus used, the Jacobsen Germinating Apparatus a, is a Danish invention, and is now employed in the seed 


\section{7}

testing institutions at Zürich, Eberswalde and Hamburg, and a number of others in Europe, as, for example, in Holland, Norway and Sweden, at any rate for the more difficult kinds of seeds, especially forest seeds.

At the International Conference on Seed-testing in Hamburg in 1906, Dr. Stebler, Director of the Zürich Seed-testing Institution, extolled the Jacobsen Apparatus as the best, especially for the seeds most difficult to deal with. Chr. P. Jacobsen (1841-95) founded in 1874 the largest Danish Farm-seed Establishment, "Markfrökontoret" in Copenhagen, which was the first commercial firm - not only in Danmark, but probably in the whole world - to carry out the principle, that all seed should be tested before being issued to the farmer. This firm was the pioneer of the scientific seed trade, and it still plays an important part.

During the twenty-five years that have elapsed since the Author entered the seed trade, a large number of reports of the results of seed tests with accompanying notes have been published by him in various brochures and journals, - particularly the following:

"Analyser af "Skovfrökontoretus Frö for Sæsonen 1887-88«.

"Skovfrökontorets Analyseresultater 1888-89 «.

"Analyser af Skovfrökontorets Frö i Sæsonen 1889-90.

\begin{tabular}{|c|c|c|c|c|c|}
\hline 》) & D & D & 》) & " & $1890-91$. \\
\hline$D$ & $D$ & D & D & ") & 1891-92. \\
\hline ) & D & D) & D & $D$ & $1892-93$. \\
\hline 》 & ) & D & $"$ & D & $1893-94$. \\
\hline D & " & D) & $D$ & ") & $1894-95$. \\
\hline D & D & " & $D$ & D) & $1895-96$. \\
\hline ) & D & D & ) & D & $1896-97$. \\
\hline D & D & D) & D & D) & $1897-98$. \\
\hline D) & D & D) & ) & D) & $1898-99$. \\
\hline
\end{tabular}

All these twelve reports appeared in the yearly Danish catalogues of the firm.

Besides these, the following articles by the Author have been published from time to time: - „Lidt om Fröanalysers Betydning for Skovfröet" (Some remarks on the importance of Seed-testing for tree seeds) and "Brugbarheden af spirede Agern" (On the use of Germinated Acorns), in the "Tidsskrift for Skovvæsen " (Danish Journal of Forestry) Vol. XII 1900, as well as in separate reprints. 


\section{8}

In 1900 "Notes on the Importance of Tree Seed Testing ", as well as "Further Notes on Tree Seed Testing 1900-01" and Tree Seed Testing in the Season 1901-02 «, - all in the Transactions of the Royal Scottish Arboricultural Society as well as in separate reprints.

"Etwas über Samenuntersuchungen und den forstlichen Samenhandel «. 1900.

"Weiteres über Samenuntersuchungen und den forstlichen Samenhandel «. 1901.

"Noch etwas über Gehölz-Samen-Untersuchungen 1902.

iDie Gehölz-Samenuntersuchungen der Saison 1902-03a.

"Gehölzsamenuntersuchungen in der Saison 1903-04".

„Gehölz-Samenuntersuchungen in der Saison 1904-05 a.

"Forstsamenuntersuchungen in der Saison 1905-06".

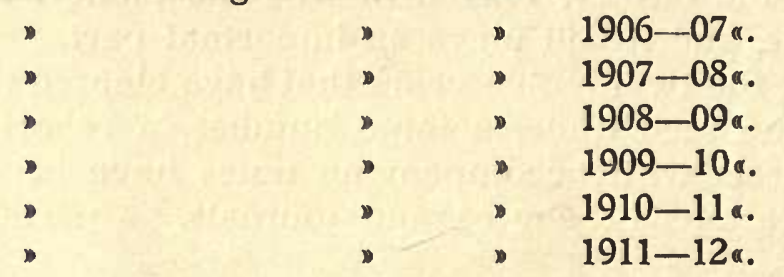

These thirteen articles are to be found in the annual volumes of the "Mitteilungen der Deutschen Dendrologischen Gesellschaft and in separate reprints.

In 1906 appeared "Analyse et Contrôle des Semences Forestières « by M. A. Fron, Professor in the Forest School of Barres (Berger-Levrault et Cie. Paris et Nancy, 1906. 128 pages in Quarto). In this treatise were included a number of the Author's results, published in the transactions of the Deutsche Dendrologische Gesellschaft" on the weight of seeds from different collecting grounds, as well as purity determinations and germination experiments, particularly on rare American and Japanese species.

These figures and notes, compiled from year to year, are collected and collated in the present work. Tables are given showing the weight, purity and utilization value of the various species of seeds. Not only the average, but also the highest and lowest figures met with during the whole period are given. In addition, the course of germination is itself set forth.

Efforts were constantly made to obtain the germination results as rapidly as possible. The earlier practice of the Seed-testing Institution was to issue a report on the germination of a sample 


\section{9}

after 10 days and a final report after 30 days. This meant a delay of a month before it was safe to send out the seed to the nurserymen. It was felt, however, that it would be an advantage, not only to the trade, but also to the Seed-testing Institution itself, if the experiments could be made as rapidly as possible. The Author, therefore, met with every encouragement and co-operation when he desired reports of the course of germination, according to a definite scheme, after 5, 10, 20, 30, \&c. days. From these reports it was sought, not only to find out after what period the germination test on any given species might safely be brought to a close; but also to enable the seed merchant to make the most rapid determination possible of a sample of seed; as it is possible, in the case of many species, with the help of the highest and lowest figures in the tables, to determine, even after 5-10 days if the final result will be good or bad. Many kinds of seed, particularly from Japan, do not reach the hands of the European seed merchants before March or April, when the spring distribution is in full swing, and it greatly facilitates the work to know after a few days that the germinating energy is so high that the good quality of the seed is evident and that it may be safely sent out.

Since, as far as is known to the Author, the "State Seed-testing Establishment" in Copenhagen is the only one of its kind which states the relative figures for germination according to a definite scheme, no tables such as those here given have hitherto been published.

In dealing with the various genera and species, an opportunity will arise of explaining these circumstances more fully, as the worst and best results are in the tables placed side by side.

Wherever germination results are mentioned in the text, decimal fractions are rounded off, fractions of 0.5 and over counting as 1.0 and those below 0.5 being neglected.

Finally, the Author recognises that what is here set forth is obviously far from being the last word on the subject; on the contrary, he sees very well that the knowledge hitherto gained and the material that is here collected, only supply the foundation for further work; the groundwork which was so entirely lacking when he began. When he thinks of the possibility of determining by means of the careful examination of the seed, whether the woods of Spruce and Pine which are to be found in Danmark, - where 


\section{0}

these species do not occur indigenously, - are of Northern or Mid-European origin - as is mentioned later - , he feels that we are only now so far advanced as to be able to proceed regularly and systematically, so that by the end of the next ten years we shall have made some real progress in the knowledge of the testing of forest seeds. If the small work that is here published is only recognised as a good beginning, the wishes and hopes of the Author will be amply fulfilled.

For the trouble taken in working out the tables which accompany this publication, the Author has to thank Miss Ingeborg Jacobsen, Assistant in the Danish State Seed-testing Establishment and daughter of the deceased Chr. P. Jacobsen mentioned above.

The Author also desires to express his indebtedness to Professor Fraser Story and Mr. Thomas Thomson of the University College of North Wales, Bangor, who kindly undertook the translation of the work into English.

Köbenhavn (Copenhagen), 1915.

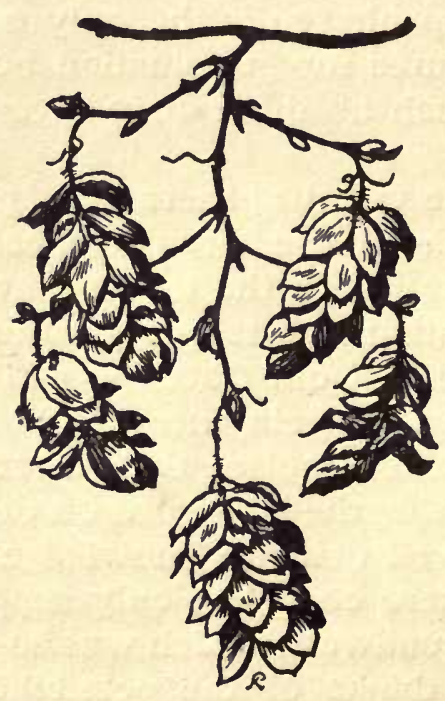



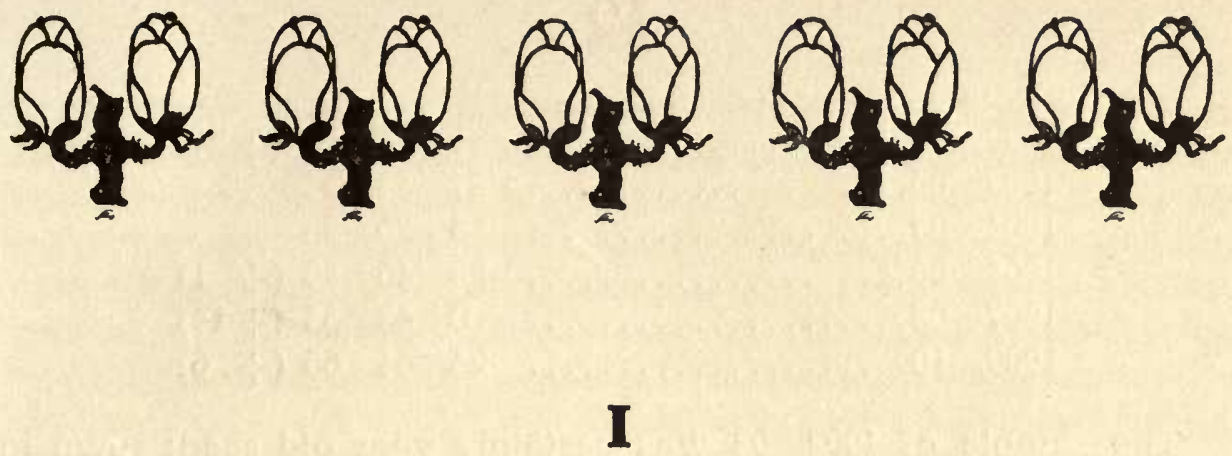

\section{THE EUROPEAN, WEST-ASIATIC AND NORTH-AFRICAN CONIFERS}

\section{ABIES}

EUROPEAN SILVER FIR - ABIES PECTINATA. During my business career the tree-seed trading houses of Central Europe have gone in for seed testing more and more. That America and Japan do not as yet do so, is easily understood; their new Seedtesting Institutions are government establishments which are only available for State officials. At the present time seed testing establishments are being founded in England, Scotland and Ireland.

But, as stated above, in Germany and Austria they are beginning; though I have not yet succeeded in receiving a single offer of Silver Fir seed with information as to its germinating capacity. On the other hand, in recent years in the wholesale trade the seeds of Larch, Common Pine, and Norway Spruce, and several other species of Spruce and Pine are offered with information as to their germinating capacity. The offers of Silver Fir seed are always accompanied only by a sample with particulars of the results of the examination of cut seed. This, however, offers only a small guarantee, for I have not yet gone so far that I can tell with absolute certainty by a cut test if I am dealing with old or new seed. As regards the seed of the common Silver Fir, our "Dansk Frökontrol" can cause it to germinate if it is new and good; year old seed either does not germinate at all, or only to the extent of some very few per cent.

I quote here a few of the most reliable experiments of the last 10 years: 


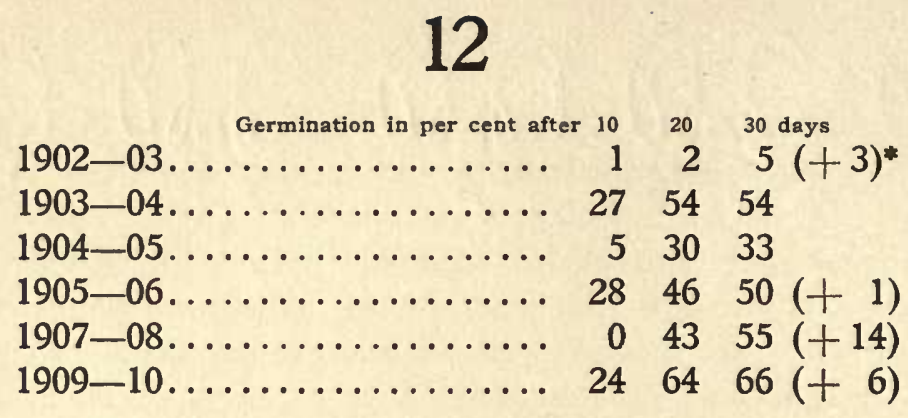

The sample of 1902-03 was certainly year old seed; sown in the nursery it would not have come up at all - it being an established fact that seeds which germinate badly in the germinating apparatus do so still worse, if at all, in the ground. It appears also, that in three of the years mentioned, the energy of germination was so high that the 10 day figures showed with certainty that the seed was good, and the 20 day germination was so high that the experiment could quite well have been brought to a close. In the year 1904-05 the bad 10 day result of only 5 per cent showed that the germinating energy was small, and the final result after 30 days is in agreement with the bad beginning.

On the other hand, 1907-08 shows a difference. The 10 day germination is 0 , but after 20 days the result is already good, and the 30 day result: $55 \%$ germinated plus $14 \%$ sound, but not yet germinated seeds, - shows that the experiment might with advantage have been continued for another ten days. The question presents itself: why this different result in 1907-08, when the seed in the three other years was in full germination after 10 days? This is not an easy question to answer. Perhaps, from causes hitherto unknown, the germinating energy of the seed changes from one year to another, perhaps the germinating experiment of 1907-08 was carried out at a lower temperature than in the other years. I do not know and I have not investigated the technique of seed testing; it is not in the sphere of my work. During the last 10 years, I have always placed unbounded confidence in the untiring energy and circumspection with which our "Dansk Frökontrol" has worked in the interests of seed research and of the seed trade, so I am convinced that the best possible was done. But, obviously, progress has not said its last word in this matter; on the contrary, the officials of the Seed-testing Institution and I

* The figures given in brackets refer to the number of seeds still sound, but not yet germinated after a certain number of days. 


\section{3}

are certainly at one in believing that knowledge of the ways and means of bringing difficult seeds to germination is still in its infancy.

CAUCASIAN SILVER FIR - ABIES NORDMANNIANA. To cause this species to germinate is much more difficult. If we examine the results of the last ten years, it almost looks as if the difficulty of the experiment was an increasing one; this is, however, only apparently the case. The first three germination experiments were carried out in Chrisstiansstad in Sweden, where a seed was considered as germinated as soon as the husk was split and the young shoot visible and fresh; in the "Dansk Frökontrol" here in Copenhagen it is required that the shoot should actually protrude.

$\begin{array}{lrrrll}\text { Germination in per cent after } 10 & 20 & 30 & 60 & 100 \text { days } \\ 1902-03 \ldots \ldots & 1 & 25 & 39 & & \\ 1903-04 \ldots . & 10 & 40 & 50 & & \\ 1904-05 \ldots \ldots & 0 & 0 & 50 & & \\ 1905-06 \ldots \ldots & 0 & 0 & 2 & 11(+16) & \\ 1907-08 \ldots \ldots & 0 & 0 & 1 & & 49(+8) \\ 1908-09 \ldots \ldots & 0 & 0 & 2 & & 26(+15) \\ 1909-10 \ldots \ldots & 0 & 0 & 2 & 56(+5) \\ 1910-11 \ldots \ldots & 0 & 0 & 1 & & 29(+1)\end{array}$

Experience shows that the seed of the Caucasian Silver Fir germinates much more slowly in nurseries than does that of the common Silver Fir, and the results of germination tests point either to autumn or very early spring sowing, or - what may be still better - submitting the seed to a careful soaking and pre-germination before sowing.

This seed, indeed, seldom shows its true utilization value through an artificial germination test.

The best consignment of this species I ever had, was that of the season 1909-10, which showed by a cut test 70-75\% of good seeds and gave in the nurseries of the Danes Buch \& Hermansen in Halstenbek in Holstein fully 20,000 plants per bed $12 \mathrm{~m}$ long and $1.10 \mathrm{~m}$ broad. (Nearly all seed beds in Halstenbek have these dimensions.) Yet the artificial germination test gave, after 100 days, only $56 \%$ germinated, plus $5 \%$ sound, but not yet germinated, seeds. As a rule, the Caucasian Silver Fir gives fully 10,000 plants per bed, which is the normal crop. 


\section{4}

THE GREEK SILVER FIR - ABIES CEPHALONICA - germinates, when the seed is good, about the same as the common Silver Fir.

The best results were obtained in the years:

$\begin{array}{llllll} & \text { Germination in per cent after } 10 & 20 & 30 & 40-50 \text { days } \\ 1909-10 \ldots \ldots \ldots \ldots \ldots \ldots \ldots \ldots \ldots & 0 & 38 & 40 & 61 \\ 1910-11 \ldots \ldots \ldots \ldots \ldots \ldots \ldots \ldots & 2 & 51 & 73 & 79\end{array}$

As a rule however, the seed is much poorer in quality.

THE CILICIAN FIR - ABIES CILICICA - appears very capricious.

$$
\begin{aligned}
& \begin{array}{cccccc}
\text { Germination in per cent after } 10 & 20 & 30 & 40 & 100 \text { days } \\
1909-10 \ldots \ldots \ldots \ldots & 0 & 0 & 0 & 1 & 82(+14)
\end{array} \\
& 1911-12 \ldots \ldots \ldots \ldots .1124 \quad 85 \quad 94
\end{aligned}
$$

In both cases the results of sowings in forest nurseries were good.

THE NUMIDIAN FIR - ABIES NUMIDICA - behaves in the same manner:

$$
\begin{array}{cccccc}
\text { Germination in per cent after } 10 & 20 & 30 & 40 & 100 \text { days } \\
1908-09 \ldots \ldots \ldots \ldots \ldots & 0 & 0 & 2 & 7 & 30 \\
1911-12 \ldots \ldots \ldots \ldots & \ldots \ldots & 2 & 16 & 41 & 48(+2)
\end{array}
$$

THE SPANISH FIR - ABIES PINSAPO - is easier to deal with, and germination proceeds as with Abies pectinata:

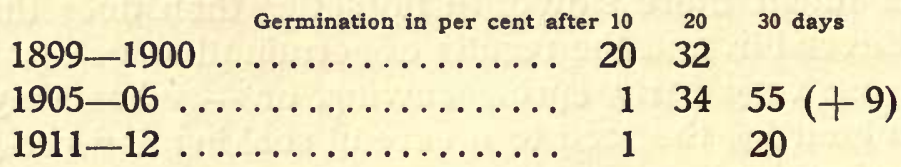

The same picture is always presented; sometimes the seed germinates immediately, sometimes it begins very slowly and in spite of this often finishes up well. The years mentioned above show the extremes.

ABIES PINDRAU and ABIES WEBBIANA seeds I have only received during the last two years. They came directly from the Himalayas, but, because the seed weight of the two species was about the same and its outward appearance is identical, I am not sure of the genuineness of the seed. Some authors throw the two species together, while others - like $\mathrm{H}$. Mayr - consider them as separate, and rightly so. But I don't know with certainty whether I 


\section{5}

have obtained from the Himalayas seed of one or both species; I have never seen European gathered seed.

SIBERIAN SILVER FIR - ABIES SIBIRICA. This seed is much in demand for Finland and Russia. For this reason I have instituted a considerable number of tests - 16 in all. This soft compatively small seed is very easy to work with in seed testing. This is shown by the three last experiments:

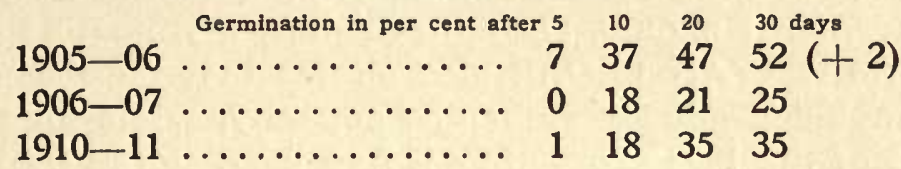

The seed of the year 1905-06 is the best I ever had; but not a single one of the 15 years sets was worthless.

\section{THE CEDARS}

In considering the results given by the CEDARS, the first thing that strikes one is the great difference in the seed weight, and as is natural with these soft juicy seeds - a low seedweight often corresponds with a low germinating capacity, though unfortunately not always. Otherwise the seed weight would be a great help in enabling one to estimate rapidly the real value of the seed. There may be something in it however, as may be seen from the following germination tests:

\begin{tabular}{|c|c|c|c|c|c|c|c|c|}
\hline \multirow[b]{2}{*}{ Cedrus } & \multicolumn{8}{|c|}{ Germination in per cent afte } \\
\hline & lantica & $1905-06 \ldots$ & $\ldots \ldots \ldots$ & 101.0 & 0 & 2 & 9 & $91+$ \\
\hline D & 》 & $1906-07$. & & 85.7 & 4 & 42 & 70 & $74(+1$ \\
\hline 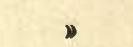 & ) & $1907-08 \ldots$ & ....... & 61.4 & 0 & 7 & 29 & $41(+25)$ \\
\hline ע & 》 & $1908-09 \ldots$ & $\ldots \ldots \ldots$ & 57.8 & 0 & 0 & 1 & $5(+38)$ \\
\hline 》 & D & $1909-10 \ldots$ & & 58.7 & 0 & 6 & 25 & $281+$ \\
\hline & " & $1910-11$. & $\cdot$ & 56.2 & 0 & 0 & 1 & $6(+40)$ \\
\hline 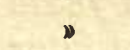 & 》 & $-12 \ldots$ & $\ldots \ldots \ldots$ & 89.0 & 9 & 40 & 55 & $691+$ \\
\hline 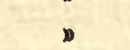 & Libani & $1901-02$. & & 138.0 & 0 & 5 & 30 & 92 \\
\hline 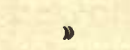 & D & $1902-03$. & $\cdots$ & 71.9 & 2 & 4 & 9 & $10(-$ \\
\hline D & ఎ & $1903-04 \ldots$ & $\ldots \ldots \ldots \ldots$ & 50.0 & 0 & 8 & 12 & 50 \\
\hline & ” & -05 . & & 59.8 & 0 & 9 & 19 & 56 \\
\hline ) & ע & $1911-12$. & .. & 121.0 & 4 & 21 & 31 & 36 \\
\hline * & Deodara, & crop 1902 , & $1903-04$ & 92.0 & 0 & 0 & 13 & 13 \\
\hline ) & ఎ & \1903, & $1903-04$ & 157.0 & 0 & 12 & 35 & 75 \\
\hline ט & 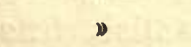 & ఎ & $1908-09$ & 151.0 & 12 & 15 & 30 & 77 \\
\hline D & D & 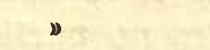 & $1911-12$. & 170.0 & 0 & 8 & 28 & 72 \\
\hline
\end{tabular}




\section{6}

In the case of the ATLAS CEDAR the three annual sets 1908-09 to 1910-11 show that low seed weight is accompanied by low germinating capacity. The years $1906-07$ and $1911-12$ with high seed weight and high germinating capacity are normal, while on the other hand, 1905-06, with the highest found seed weight and the lowest germinating capacity again upsets the theory.

With the LEBANON CEDAR the highest found weight again corresponds, as it should, with the highest germinating capacity.

The HIMALAYAN CEDAR also shows that high seed weight has accompanied good germinating capacity, while on the other hand seed of the 1902 crop, after it had been stored by me for a year, lost seriously in weight and germinating power.

\section{LARCH}

THE COMMON LARCH-LARIX EUROP EA. With this seed it is now much easier and pleasanter to deal than it was in the past. Let us take some of the most striking figures out of the 23 tests on Tyrolese seed:

\begin{tabular}{|c|c|c|c|c|c|c|}
\hline & Germination in per cent a & & & 20 & $30^{\circ}$ & \\
\hline $1894-95$ & ................. & 0 & 4 & & & \\
\hline $1895-96$ & $\ldots \ldots, \ldots, \cdots$, & 0 & 5 & 29 & & 64 \\
\hline $1905-06$ & $\ldots \ldots, \ldots, \ldots, \ldots$ & 0 & 26 & 36 & 36 & \\
\hline $1906-07$ & ..... & 1 & 27 & & 38 & \\
\hline $1907-08$ & $\ldots$ & 1 & 47 & 54 & & \\
\hline $1908-09$ & $\cdots$ & 0 & 21 & 31 & & \\
\hline $1909-10$ & $\ldots$ & 31 & 51 & 53 & & \\
\hline $1910-11$ & $\ldots \ldots \ldots$ & 12 & 39 & 42 & & \\
\hline $1911-12$ & Lot $I \ldots \ldots \ldots \ldots$ & 35 & 51 & 51 & & \\
\hline $1911-12$ & Lot II $\ldots \ldots \ldots \ldots$ & 23 & 57 & 57 & & \\
\hline
\end{tabular}

One is immediately struck by the fact that, while sixteen years ago it required 40 days to attain the final result, ten years later half this period was sufficient, and the season 1911-12 showed the best result of the whole twenty-five years, as both samples had completed their germination in 10 days.

In the table of average figures, it will be found that Common Larch from different districts (places of origin) is compared. Swiss seed (from the Engadine) seems to have the largest grains, but the number of samples is too small to establish this with certainty. The seed from Silesia deserves no particular notice, for 
the seed which the merchants of Silesia bring into the market, is either bought in the Tyrol or collected in Silesian forests, which are unfortunately made impure by admixture of Tyrolese Larch. I say "unfortunately", because there is a Polish-Silesian variety which is distinguished by its slender growth and by the fact that its side twigs are small and stand at an acute angle with the stem, a variety which approaches in growth the fine Siberian Larch. The Silesian Larch would be well worth a trial in Scandinavia (Danmark and Southern Norway and Sweden) and Great Britain and Ireland, if one could be certain of genuine seed, possibly rather from Poland than from Silesia, as the natural forests in the former district might be the purest.

THE SIBERIAN LARCH - LARIX SIBIRICA. It has been a matter of dispute for many years as to whether the Siberian Larch should be considered a species, or if it is only a geographical variety of the European Larch. Judging from the size of the seed, the difference is so pronounced that the Siberian Larch must be allowed an independent position. The weight of the seed varies between 8.05 and 12.04 grams per 1000 grains, while that of the Tyrolese Larch only amounts to from 4.66 to 6.6 grams. True, we find the same great difference in seed weight in other species. For example, spruce seed from Northern Norway only weighs about half as much as that from the lowlands of Central Europe, and Pinus monticola seed from Northern Idaho, near the Canadian border, only weighs half as much as seed from California. In these cases however, there comes into play a factor which will be fully dealt with later, - the natural falling off of seed weight in higher latitudes as well as in higher altitudes, in consequence of the increased severity of the climate of the place of origin.

The germinating capacity of Siberian Larch seed is often good; the difficulty principally consists in the obtaining of the seed, and this difficulty has been increasing of late years. As a result, one must often be contented with very poor seed. A few years ago good seed often came into the market, more recently on the other hand, only that of bad quality; in the last two years 1911-12, I have been unable to obtain any at all.

The following may serve as examples of the germination experiments: 


\begin{tabular}{|c|c|c|c|c|c|}
\hline $\begin{array}{l}\text { Germination in per cent af } \\
1896-97 \ldots \ldots \ldots \ldots \ldots\end{array}$ & $\begin{array}{r}\text { er } 5 \\
0\end{array}$ & $\begin{array}{l}10 \\
29\end{array}$ & 20 & 30 & $\begin{array}{l}40 \text { days } \\
55\end{array}$ \\
\hline $1897-98 \ldots \ldots \ldots \ldots \ldots$ & & & 55 & & 60 \\
\hline $1898-99 . \ldots \ldots \ldots \ldots \ldots$ & & 50 & & 56 & \\
\hline $1899-1900 \ldots \ldots \ldots \ldots \ldots$ & & 40 & 46 & & \\
\hline $1902-03 \ldots \ldots \ldots \ldots \ldots$ & 24 & 37 & 37 & 37 & \\
\hline $1903-04$ I. . . . . . . . & 0 & 2 & 3 & & 3 \\
\hline $1903-04$ II . . . . . . . . & 0 & 1 & & & 2 \\
\hline $1903-04$ III . . . . . . . & 0 & 14 & & 21 & \\
\hline $1906-07$ I. . . . . . . & 0 & 15 & 17 & 17 & \\
\hline $1906-07$ II . . . . . . . . & 14 & 28 & & 32 & \\
\hline $1909-10$ I . . . . . . . . . & 1 & 20 & & 25 & \\
\hline $1909-10$ II . . . . . . . . . & 0 & 7 & & 10 & \\
\hline
\end{tabular}

THE SPRUCES - PICEA

THE COMMON SPRUCE - PICEA EXCELSA. The seed of this species was always easily caused to germinate, provided the seed was good, as it generally is. For this reason, no improvement or alteration in the course of germination is to be found, when the figures of the earliest years are compared with those of the most recent. Even in the first few years the seed-testing establishment was able in 10 days to obtain a germination of $80-90 \%$, and it is the same to-day. At first the test was carried on, as was usual, for 30 days, but about 20 years ago we began to stop sooner. This is evident from the germination results which are here extracted (with 5-yearly intervals) from the 57 Mid-European samples.

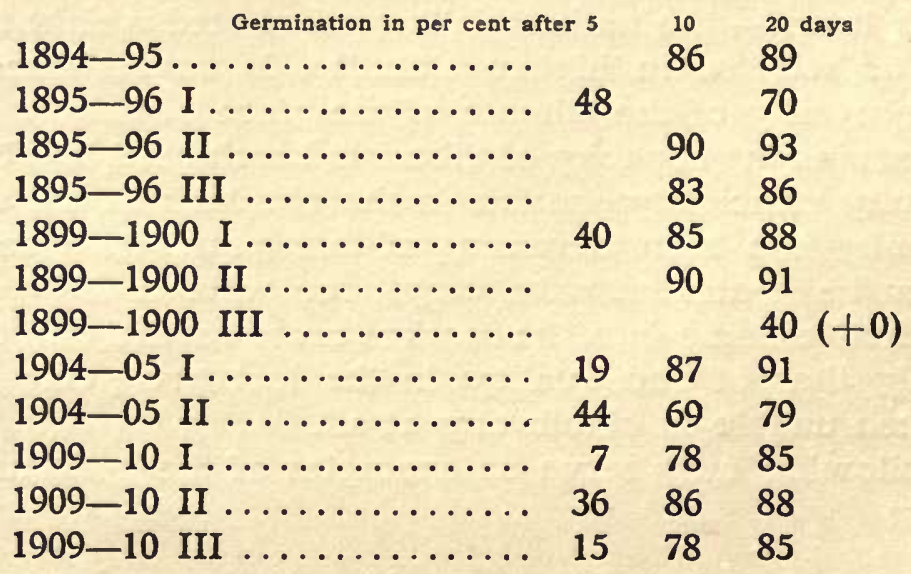


In the season 1911-12, the Mid-European seed was some years old, and was the worst lot but one I have ever had; it germinated only $53 \%$. The worst lot was III 1899-1900. When in the column $\$ 5$ days " only a few figures appear in the earlier years, this is naturally accounted for by the fact that the germination after 5 days has not been regularly counted, or at least not carried out in accordance with the scheme drawn up by me.

Danish grown spruce seed is never particularly good. The collectors are not able to clean it well, because it is always dealt with only in small quantities. Some figures regarding the course of germination may be of interest, as the seed is Danish:

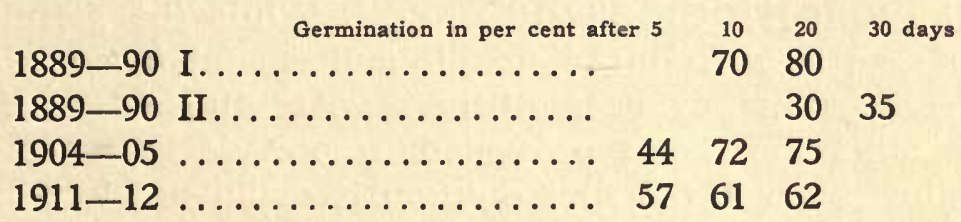

Norwegian and Swedish spruce seed is, on the other hand, a first class article, which, when there is a good harvest of cones, especially in Sweden, plays an important part, and it is as a rule Swedish seed which gives the highest germinating percentage of all. The season 1888-99 shows this splendidly:

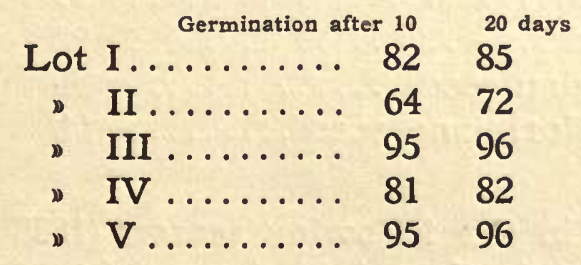

Since Norway and Sweden have had no cone harvest of recent years, the real value of the seed has fallen off very much, because the kilns have had to be satisfied with cones several yaers old. This is shown by the following figures for Småland (Central or mid-Sweden) seed:

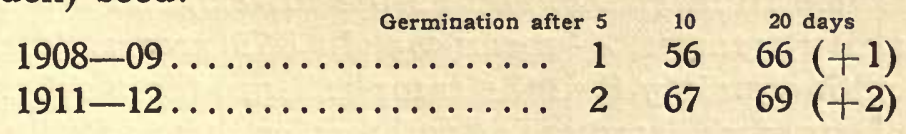

As an energetic propaganda was made from Norwegian sources (Forstmester Glöersen) thirty years ago, in favour of the We- 


\section{0}

stenfjeldske Nordlands spruce (Picea excelsa borealis), many experiments were made with it on the heaths of Jutland, which were however quickly abandoned because the plants grew far too slowly. If new, the seed was good and kept extremely well, but in the North of Norway cone years are very rare. In my report of 1888-89 I mention as an example of its keeping qualities, a sample of seed of Picea borealis, which was received from Forstmester Glöersen and was 5 years old, but nevertheless germinated $48 \%$ in 23 days. In 1896-97 I had a small lot of new seed which was excellent, as it germinated $95 \%$ in 10 days and $96 \%$ in 15 days.

THE WEIGHT OF SPRUCE SEED. While the germination of spruce seed has produced no difficulties and brought about no great changes or advances all these years, the weight of the seed on the other hand, has presented a good deal that is new and interesting. Even in the first autumn it could not but be noticed that there was an important variation in seed weight, and in my report on the research results for 1887-88 it was pointed out that the first four spruce seed tests carried out for me by the "Dansk Frökontrol " showed this clearly, as follows: -

\begin{tabular}{|c|c|c|c|c|}
\hline & Purity & d weigh & ermina & ting \\
\hline German s & 99 & 9.01 & & \\
\hline Swedish seed & 98 & 5.48 & 80 & • \\
\hline East Norwegian seed & 90 & 5.57 & 84 & • \\
\hline Norwegian Northland seed & 98 & 4.01 & 44 & \\
\hline
\end{tabular}

This caused me in the following season (1888-89) to undertake a number of investigations into the weight of the seeds both of spruce and Scots pine from many different European districts, and these abundantly confirmed the results of the first year.

Seven spruce seed samples from seed merchants in Hesse, Bavaria, Thuringia and Austria gave as the highest seed weight, 9.24 for the sample from Hesse, and as the lowest, 8.01 for one of the three Austrian samples, - mean weight 8.75 grams. It cannot be assumed with certainty that the samples from these different parts of the country came from cones gathered in these neighbourhoods; they were only samples of trade seed, and the cones might quite well have been sent to the kilns from other districts. 


\section{1}

Two samples from DANMARK - from Viborg and Feldborg in Jutland - weighed 7.47 and 7.76 grams.

Nine samples from Norway-Sweden gave a mean weight of 5.3 grams. Three samples from Southern Sweden weighed 5.47, 6.0 and 6.02; three from East Norway 5.26, 5.38 and 5.56, one from West Norway from Vos 5.16, and on from Northland in Norway 4.09 grams.

One Finland sample: 4.82 grams.

The weight results for Pine seeds will be more fully set forth later. As time went on, these observations of the first year, now 24 years old, were further confirmed. As is to be seen from the attached table, the highest average seed weight for 57 Mid-European Spruce samples was 9.68, the lowest 6.73. Mean weight 8.06 grams.

The highest seed weight for Danish seed 8.87, the lowest 6.84 , mean 7.97.

Finland seed, highest 5.5, lowest 3.97, mean 4.97. Norwegian and Swedish seed, highest 6.02, lowest 5.07 , mean 5.60 .

Norwegian Northland seed, highest 5.16, lowest 4.10, mean 4.74.

A sample from the Urals in 1908 weighed $4.56^{*}$

The seed of the SIBERIAN SPRUCE - PICEA OBOVATA shows in the highest case 5.76 , in the lowest, 4.45 , mean 4.86 grams, and seems to indicate the possibility that this spruce is only a form which most closely approaches the Finland-Scandinavian spruce.

In order to determine if this higher or lower seed weight was hereditary when the trees are grown in Danmark, and the weight of the seeds in consequence could perhaps be used to determine if our old spruce woods are of Scandinavian or Mid-European origin, I sought carefully for several years to obtain cones with good, fully ripened seeds from two old woods in the forests of Vestre-Palsgaard and Rold Skov in Jutland, which according to tradition were raised from Norwegian seed. In Jutland, however, the flowers of the spruce are often destroyed by late frosts, so that my object was only attained for the first time in 1911. The weight determinations, according to the certificates Nos 75931 and 75932 of the "Dansk Frökontrol ", gave the following results:

- Later CIESLAR has demonstrated that the same fall in the weight of Spruce seeds is shown also with increased elevation, such as in the mountains. Seed from high elevations is considerably smaller than that from the lowlands. - Professor Dr. A. Cieslar: Die Erblichkeit des Zuwachsvermögens bei den Waldbäumen (Centralblatt für das gesamte Forstwesen 1895). 


\section{2}

Spruce seed from Vestre Palsgaard, Jutland, compartment 74, a very well grown wood 80 years old, 30-35 metres high; from weighing $5 \times 100$ seeds: 7.17 grams per 1000 seeds.

Spruce seed from trees about 35 years old in Fræer Purker, Lindenborg, in Jutland; from weighing $5 \times 100$ seeds: 4.37 grams.

Spruce seed from Rold Skov, Jutland; $2 \times 100$ seed: 8.90 grams per 1000 seed.

The trees in Vestre Palsgaard and Rold Skov may therefore belong to a Mid-European strain, those in Fræer Purker to a Scandinavian one.

The germinating capacity appeared to be good. An exactly similar result for several Pine seeds will be discussed when referring to that species.

With the three other species of spruce - those from the Himalayas, the Balkans and the Caucasus - I have hitherto had little to do; though I think the CAUCASIAN SPRUCE, Picea orientalis a very valuable tree, well worthy of more extended cultivation as soon as cheaper seed can be obtained. The real value of the seed is generally good: in the three last seasons it was as follows:

\begin{tabular}{|c|c|c|c|}
\hline & & \multicolumn{2}{|c|}{ Germination in per cent after } \\
\hline & Purit & $\begin{array}{ll}5 & 10 \\
1 & 71\end{array}$ & \\
\hline 1910 & 000 & 39 & 3) \\
\hline 191 & 99.8 & 49 & $86(+1)$ \\
\hline
\end{tabular}

\section{THE PINES. - PINUS.}

The four allied species - PINUS AUSTRIACA, P. CALABRICA, P. LARICIO and P. PALLASIANA - may well be discussed together, for in the seed tests they differ from one another only in the size of the seeds. The mean seed weights amounted to 18.8, (21 samples), 17.1 (6 samples), 14.8 (22 samples), and 23.7 (4 samples) respectively.

The germinating capacity is often first rate, but also often very moderate, because the seed quickly falls in germination power if stored from year to year. In 1909-10 the seed of the Austrian Pine was particularly good, I therefore caused the germinating capacity of the same lot to be tested in the three successive years and obtained the following results: 


\section{3}

\begin{tabular}{|c|c|c|c|c|c|}
\hline \multirow[b]{3}{*}{$1909-10$} & \multirow{2}{*}{\multicolumn{2}{|c|}{ Seed weight. Purity }} & \multicolumn{3}{|c|}{ Germination in per cent after } \\
\hline & & & 5 & 10 & 20 days \\
\hline & 18.9 & 99.2 & 38 & 81 & $89(+1)$ \\
\hline 1910 -11 & 19.0 & 98.8 & 12 & 55 & $73(+4)$ \\
\hline $1911-12$ & 19.0 & 98.8 & 2 & 31 & $46(+0)$ \\
\hline
\end{tabular}

The seed does not lose in weight, but the germinating energy falls rapidly; in 1911-12 it had become practically worthless. The great loss of germinating energy at five days is particularly noticeable. - A similar test with the CORSICAN PINE showed pretty much the same result:

\begin{tabular}{|c|c|c|c|c|c|}
\hline & & & \multicolumn{3}{|c|}{ Germination in per cent afte } \\
\hline & Seed weight & Purity & 5 & 10 & 20 days \\
\hline $1909-10$. & . $\quad 12.7$ & 98.1 & 17 & 67 & 84 \\
\hline 1 & & & 8 & 45 & 67 \\
\hline & & & 9 & 47 & 64 \\
\hline
\end{tabular}

Similar behaviour is also shown by PINUS PALLASIANA from the Crimea:

\begin{tabular}{|c|c|}
\hline & $\begin{array}{l}\text { Germination in per cent afte } \\
\text { new seed } \ldots \ldots \ldots \ldots\end{array}$ \\
\hline 1907 & same lot... \\
\hline $909-10$ & D D \\
\hline $9-10$ & new seed... \\
\hline
\end{tabular}

In 5 years the germinating capacity of the seed of 1904-05 sank from $87 \%$ to $10 \%$.

PINUS MONSPELIENSIS SALZM. (Pinus Laricio Pyrenaica) is a species whose name has been changed from time to time, but I believe botanists are now agreed as to its place in the system as well as its worthlessness for cultivation.

The seed germinates well as a rule; not once have I had bad seed. The last two samples may quite well be taken as typical:

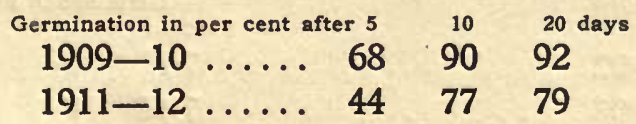

Several of the following species which are little in demand are treated together, in order to give the seed trade a representation of the most favorable instances of germination; the maximum and minimum figures will be found in the tables. 


\begin{tabular}{|c|c|c|c|c|c|c|}
\hline inus & $\begin{array}{l}\text { Germination in per cent after } \\
\text { canariensis } 1910-11 \ldots\end{array}$ & $\begin{array}{l}5 \\
0\end{array}$ & $\begin{array}{r}10 \\
47\end{array}$ & $\begin{array}{r}20 \\
86\end{array}$ & ${ }^{30} 8(+1)$ & 100 days \\
\hline 》 & excelsa $1908-09 \ldots$. & 0 & 17 & 93 & & \\
\hline 》 & $\begin{array}{cc}\text { Gerardiana } & 1908-09 . \\
\text { (same lot) }\end{array}$ & 0 & 14 & 48 & $56(+17)$ & \\
\hline 》 & $\begin{array}{l}1910-11 \ldots \ldots \ldots \\
\text { halepensis } 1907-08 \ldots \\
\text { leucodermis, undoub- }\end{array}$ & & $\begin{array}{l}4 \\
5\end{array}$ & $\begin{array}{l}38 \\
66\end{array}(+16)$ & $89(+2)$ & \\
\hline D & $\begin{array}{l}\text { tedly old seed,1908-09 } \\
\text { leucodermis (same lot) }\end{array}$ & & 1 & 7 & 12 & $27(+62)$ \\
\hline D & $\begin{array}{r}1909-10 \ldots \ldots \ldots \\
\text { longifolia } 1908-09 \ldots\end{array}$ & 1 & $\begin{array}{r}0 \\
88\end{array}$ & 91 & & $13(+5)$ \\
\hline 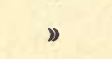 & maritima $1910-11 \ldots$ & 0 & 14 & 80 & $88(+4)$ & \\
\hline
\end{tabular}

Pinus Cembra from the Tyrol and Pinus Cembra from Siberia, P. Siberica, as $\mathrm{H}$. Mayr calls it, both germinate so slowly that the seed must be prepared nstratified " in the nurseries for a year before being sown. For this reason also it cannot be brought to germination in reasonable time by artificial means. Quite exceptionally, it has been possible to obtain the following result from Tyrolese seed: 10 days $10 \%-40$ days $15(+75) \%$.

MOUNTAIN PINE - PINUS MONTANA. The extensive employment of the Mountain Pine in Danmark as a nurse for the spruce in plantations on the heaths of Jutland, has naturally brought with it a large number of tests of this seed; 86 samples in all, if the three forms - the single-stemmed, the ordinary many-stemmed Mid-European and the creeping forms - are taken together.

If the seed is good, germination goes smoothly from the start. The highest germinating energy (1902-03) and the lowest germinating capacity are shown by the following figures, for seed of the common Mountain pine, of Danish origin:

\begin{tabular}{|c|c|c|c|c|}
\hline \multirow[b]{3}{*}{$1901-02$} & \multicolumn{4}{|c|}{ Germination in per cent after } \\
\hline & Seed weight & & & 20 days \\
\hline & 7.6 & 38 & 93 & 98 \\
\hline $1902-03$ & 7.43 & 87 & 96 & 97 \\
\hline $1888-89$ & 5.52 & 0 & 19 & 32 \\
\hline
\end{tabular}

The highest seed weight was 8.17 , the lowest 5.52 and the mean 6.87 grams.

The seed of the French, single-stemmed Mountain Pine - Pinus 


\section{5}

montana gallica - is larger than that of the common many-stemmed form, or at least was so, for the weight seems to be decreasing, as the following figures show:

1901-02 Danish seed from Feldborg in Jutland ...... 8.5 grams

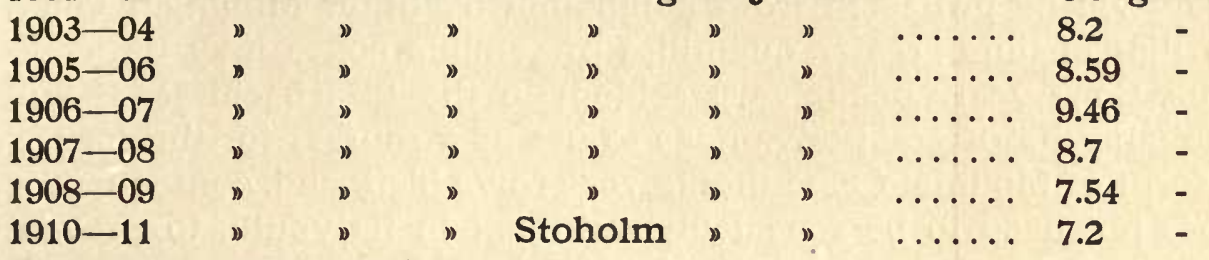

The mean weight is 8.31 grams.

In the season 1911-12, a small sample of the French Mountain Pine seed collected in the Pyrenæan mountains was submitted for testing by The Danish Heath Cultivation Society and gave the following result: Seed weight 7.6 grams, Purity $93.3 \%$, Germination after 5 days $2 \%, 10$ days $37 \%, 20$ days $55(+21) \%$. The low germinating energy and the low seed weight suggest that the seed was more than a year old, or that it was obtained from cones pulled in an unripe condition.

The falling off in weight of the seed harvested in Danmark is remarkable. The plantations in Feldborg and Stoholm are 25-30 years old and originated in seed which was obtained partly from the Pyrenees, and partly from Briançon in the Department of Hautes Alpes. The decreasing size of the seed may perhaps indicate a hybridization with the many-stemmed form of P. montana, which occurs abundantly everywhere in Jutland.

Of the CREEPING MOUNTAIN PINE - PINUS MONTANA PUMILIO - I have only had two samples during the whole time, which gave the following results:

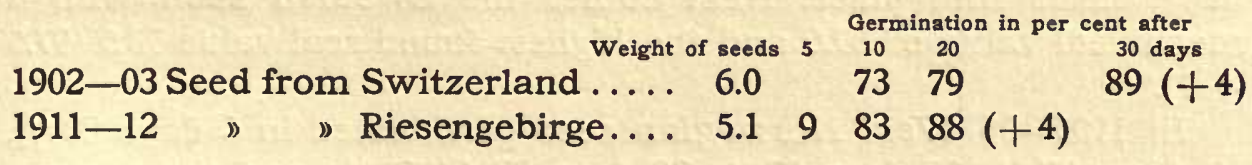

Whether the Swiss seed is of the creeping form, is perhaps doubtful. On the other hand, that from the ridge of the Riesengebirge - Hohe Schneekoppe -, which I received from the forest officers in that district, after many requests made from time to time for a number of years, should be genuine. The small cones 


\section{6}

and the smallest seed weight for Mountain Pine I ever obtained, confirm this supposition. I am in hopes of obtaining some more cones from the Riesengebirge, and it is intended to place the plants raised from the two consignments in places in Danmark where they will be protected from pollination by other Mountain Pines, so that in time greater quantities of genuine cones may be available. Cone years occur very seldom in the Riesengebirge. It will probably be of great advantage to use as a "nurse " for the spruce, a form of Mountain Pine that never grows high, and, consequently, does not need to be repeatedly cut back in its youth, to prevent the spruce suffering from its shade.

The seed of the ROUMELIAN STROBUS - PINUS PEUKE germinates very slowly and needs a wearisome treatment:

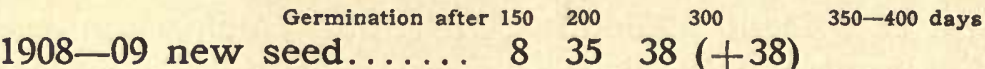

$$
\begin{aligned}
& \text { 1909-10 the same lot ... } 85(+4) \\
& \text { 1910-11 new seed...... } 89
\end{aligned}
$$

Obviously the Seed-testing Establishment cannot continue germination tests that last so long; these isolated experiments were only undertaken to show that the seed should be prepared "stratified " in the nursery for a year before sowing, else it will lie over a year in the seed beds before growing.

THE SCOTS PINE - PINUS SILVESTRIS. If the examination of the different forms is included, the figures in the tables show the results of 99 tests.

Considering first the germination results, it is obvious that the West Norwegian pine seed from "Bergens Skogselskab" with a mean real value of 91.1 and a germinating energy of $83 \%$ in 6 days, takes first place. Next comes the Swedish seed with a mean real value of 89.6 and the highest found real value 98.5 (97.5 $+1)$.*

In 1905-06 West Norwegian seed germinated in 6 days $83 \%$, 10 days $92 \%, 20$ days $93 \%, 30$ days $93(+2) \%$; and the poorest result was shown, in $1889-90$, by Finland seed: 10 days $9 \%$, 30 days $15 \%$.

\footnotetext{
- "Real value" means the number of pure and germinating seeds in 100. Thus, if a sample showed a percentage of germination 90 , and percentage of purity 80 , the real value would be $\frac{80 \times 90}{100}=72$; in other words, each $100 \mathrm{lbs}$ of seed contain $72 \mathrm{lbs}$ that are both pure and capable of germinating.
} 


\section{7}

The best and worst Scottish samples gave:

\begin{tabular}{llllllll} 
& \multicolumn{3}{c}{ Seed weight } & Purity & 5 & \multicolumn{3}{c}{$\begin{array}{c}\text { Germinstion in per cent after } \\
\text { 30 days } \\
1890-91\end{array} \ldots$} & 5.23 & 99.6 & & 83 & & $90(+6)$ \\
$1895-96$ & $\ldots$ & 6.21 & 99.5 & & 72 & 96 & \\
$1904-05$ & $\ldots$ & 7.21 & 98.4 & 43 & 72 & & $80(+1)$ \\
$1908-09$ & $\ldots$ & 6.01 & 94.6 & 33 & 78 & 88 & \\
$1888-89$ & $\ldots$ & 6 & 86 & & 33 & $42(+6)$ & \\
$1909-10$ & $\ldots$ & 7 & 92 & 4 & 25 & $39(+0)$ &
\end{tabular}

The best and worst Swedish samples:

$$
\begin{aligned}
& \text { Germination in per cent after }
\end{aligned}
$$

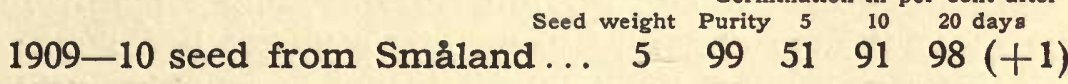

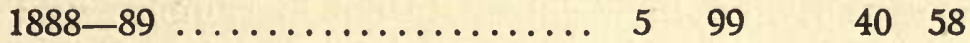

The best and worst Finland samples:

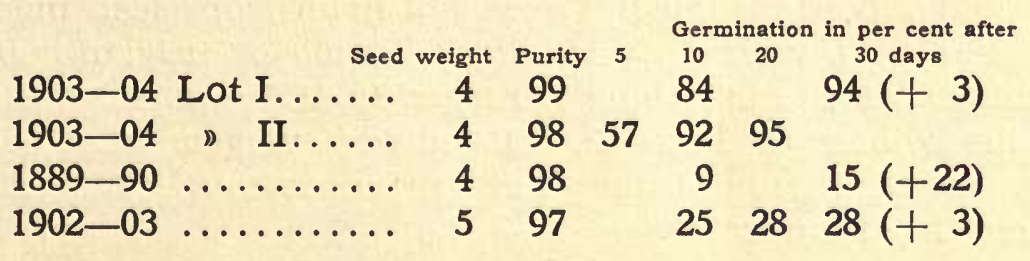

The quality of the different strains of seed is as follows:

\begin{tabular}{|c|c|}
\hline \\
\hline $\begin{array}{l}\text { Mean } \\
74.9\end{array}$ & \\
\hline 39.6 & \\
\hline 1.1 & \\
\hline .4 & \\
\hline 4.5 & \\
\hline
\end{tabular}

37 Finland samples

13 Scandinavian (mainly Swedish) .......... $89.6 \quad 98.4$

10 West Norwegian (Bergens Skogselskab) .... 91.196 .9

33 Scottish .......................... $64.4 \quad 95.6$

4 Central European (from Hartz and Belgium) $84.5 \quad 97.7$

The lowest real value is thus shown by the Scottish seed, because, unfortunately, the Scotch have the same bad habit as the Japanese in the case of the Japanese Larch, of collecting most of the cones as early as possible and therefore obtaining them before they are ripe. In a markedly insular climate, like that of Scotland, where there is much cloud and little bright sunshine, it is necessary to be doubly cautious in regard to premature collecting. It is true that the period of growth of the summer season is fairly 


\section{8}

long, considering the northern position of the country, but the amount of sunshine recorded is low in comparison with other countries situated further north - such as Northern Sweden, Finland and Siberia. In these countries cones ripen more surely and quickly than in Scotland, partly because during summer it is light, and even sunny, throughout most of the twenty-four hours.

The seed weight of the different strains, as in the case of the spruce, varies considerably. As early as $1888-89$ I called attention in my report to this, and stated that 7 Central European samples - 2 from Darmstadt, 2 from Austria, and 3 from Bavaria - weighed on the average 5.92 grams per 1000 seeds; 7 Scandinavian samples - 4 from Skåne (Sweden), 2 from Norway, and 1 from Finland averaged 4.94 grams per 1000 seeds. It is not to be taken as by any means certain that the Central European samples were obtained from cones collected in the neighbourhoods mentioned on the contrary the probability is that the samples from Darmstadt and Bavaria, though I received them from seed merchants in these places, were obtained from French or Belgian cones, for nowadays cones make long journeys. In 1904 I reported that during the winter of $1901-02,200$ railway waggon loads of pine cones were sent from France and Belgium to one Tree seed establishment in Darmstadt.*

Belgian pine seed is particularly large. In the last few years I have had to deal with small lots of Belgian and North German pine seed and caused them to be tested with the following results:

\begin{tabular}{|c|c|c|c|c|c|c|}
\hline & & \multirow{2}{*}{ Seed weight } & \multicolumn{4}{|c|}{$\begin{array}{l}\text { Germination in per cent afte } \\
\text { rity }\end{array}$} \\
\hline $09-1$ & Seed from the Harz ... & & 99.3 & 63 & 90 & 92 \\
\hline 10 & inen & 7.5 & 98.6 & 48 & 84 & 91 \\
\hline $911-12$ & • & 6.3 & 99.7 & 62 & 90 & 97 \\
\hline
\end{tabular}

These small consignments I received from reliable collectors, and they are undoubtedly from the places named.

However, seed of genuine German strain can now be obtained from several German establishments; for the importation of French and Belgian cones, whose seeds have caused such immense harm in German, Russian and Swedish forests, has been greatly restricted. Most of the kilns as well as the most reliable of the forest

* Mitteilungen der Deutschen Dendrologischen Gesellschaft pro 1904; Gehölzsamen-Untersuchungen in der Saison 1903-04. 


\section{9}

nurseries in Halstenbek are under the control of the German Forestry Council (Deutscher Forstwirtschaftsrat), and foreign cones and seeds dare not be used. To close every door, the importation of the cones of the fine strong and hardy Belgian Campiegne Pine has also been regretfully prohibited.

The seed weight results of 1888-89 have been shown to be quite correct, as, to-day after twenty-five years, Table No. I shows the following figures for the seed weight:

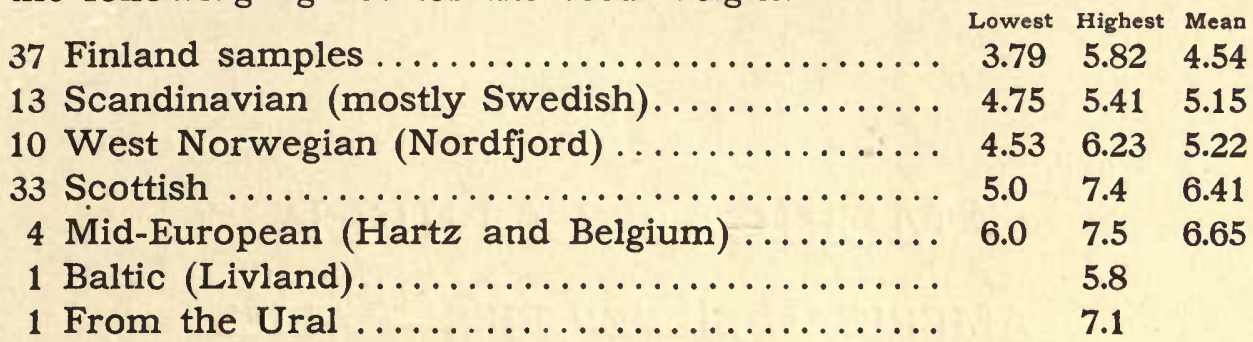

The high weight of the last sample is striking.

As mentioned above in discussing the spruce, I have tried if it is possible by means of the weight of the seed, to determine the origin of our old Danish pine woods, and I found that the results were very similar to those obtained in the case of the spruce. In 1911-12 cones were sent to me from old pines in the heath of Hald Skramsö in Jutland, and the weight of the seed was as follows:

Seed from the heath of Hald ..... (5 5100 seeds weighed $) 4.27$ grams

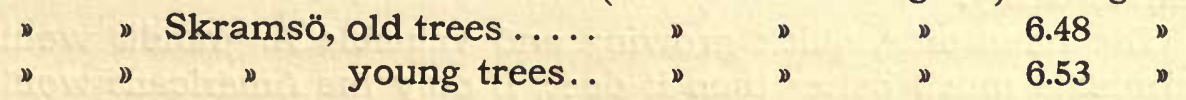

The germinating capacity is good, $16 \%, 48 \%$ and $32 \%$ respectively, in 5 days.

The pines in Hald are presumably of Northern, those on Skramsö of Mid-European, strains.

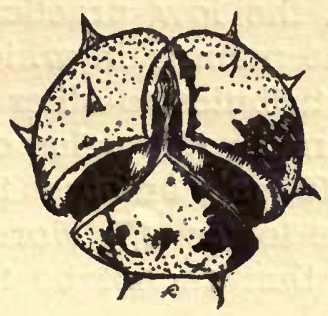



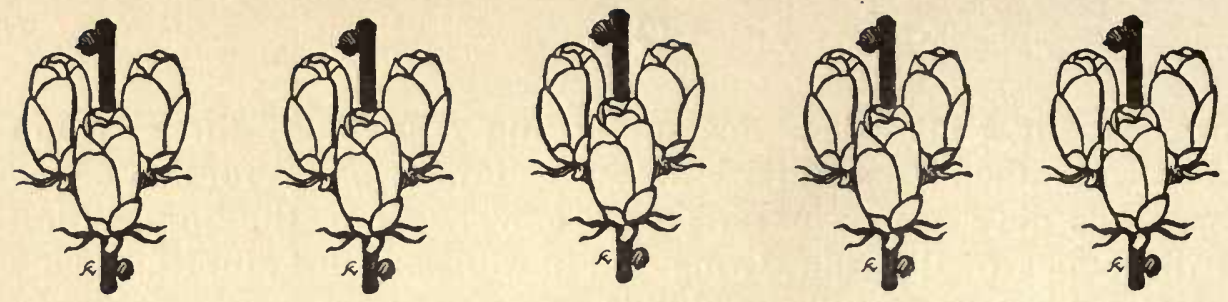

\section{II}

\section{AMERICAN CONIFERS}

\section{AMERICAN SILVER FIRS - ABIES}

The germination of the American firs runs very nearly on the same lines as that of the European species; some germinate easily, others - such as Abies magnifica - slowly and with difficulty, like Abies Nordmanniana, showing but seldom their real value in germinating tests.

The species with comparatively small seeds, A. balsamea and and A. subalpina, both belonging to the Balsam Fir group, as well as A. arizonica and A. concolor from the Rocky Mountains, germinate easily.

The handsome, quick growing and valuable A. grandis would germinate much better than it does, if only the Americans would not continue to damage the seeds by a too violent removal of the wings. I have tried for years to get this improper practice discontinued, but hitherto without success. In future I shall try to obtain the seed in an uncleaned condition and have the wings removed here.

Sometimes, however, the low practical value of this seed is not a consequence of the manner in which the wings have been removed, but must be attributed to other causes, unknown to me. As a matter of fact, the mean real value of 13 samples, as appears from the Table on page 68 , only amounts to $17.4 \%$; the highest germinating capacity 74, the lowest 4.7 . Moreover it is a fact proved by experience, and one that cannot be too strongly emphasised, 


\section{1}

that seeds that germinate but poorly in the germinating apparatus, where the conditions of temperature and humidity are as favorable as possible, do so still more unsatisfactorily, if at all, in the seed bed. Hence it obviously follows that seeds proving a real value of only 5-10\% by the artificial tests may be considered worthless.

Whether Abies concolor (glauca) from the Rocky Mountains and A. concolor (A. lasiocarpa) from the Cascade Range and the Sierra Nevada, are the same, or two separate species, authorities are not agreed. The seed from the coast of the Pacific is somewhat larger than that from the Rocky Mountains, but this is naturally not conclusive. I believe that it will ultimately be decided that we are here dealing with two different strains of the same species; for, according to my experience, seed from high elevations near the Pacific coast produces greyish blue plants of somewhat weak growth; plants, indeed, which resemble the Rocky Mountain ones, much more than the vigorous green Abies concolor from seed from the lowland forests of the Pacific coast.

The difference between these two types, however, is not nearly so great as that between the quick growing green Douglas Fir from the Pacific coast and the much slower growing glaucous Douglas from the Rocky Mountains - or between the very quick growing Shore Pine (Pinus contorta) of the Pacific coast and the slow growing Lodgepole Pine (P. Murrayana) from the Rocky Mountains, which latter two are generally - in my opinion erroneously - considered as one very variable species.

The best and worst germination results obtained with various species of Abies during the whole period are as follows:

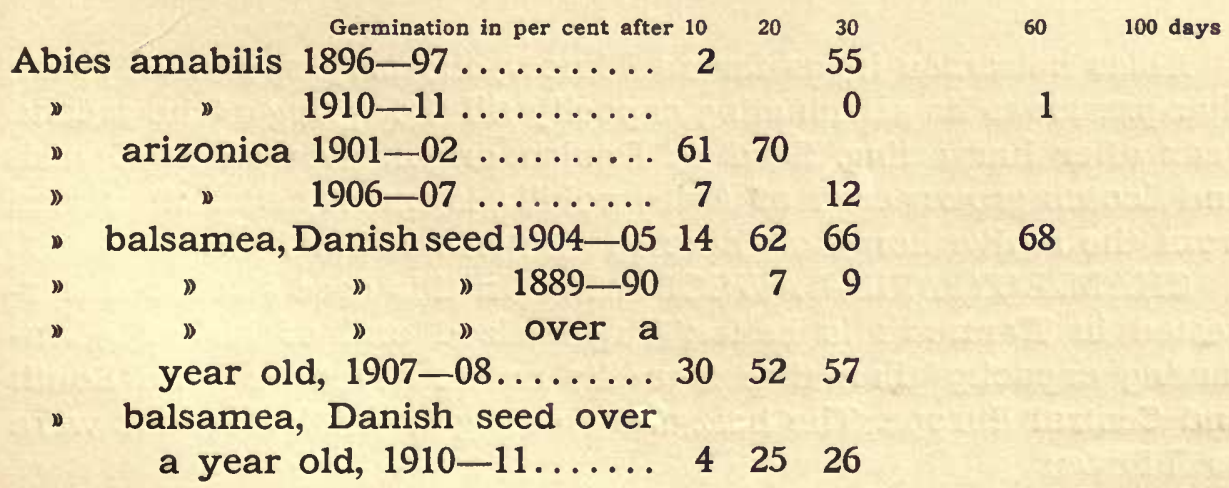




\section{2}

Abies balsamea, American seed

1905-06.............. $14 \quad 40 \quad 44(+10)$

- balsamea, American seed

$1889-90 \ldots \ldots \ldots \ldots \ldots . \quad 11$

D concolor, Rocky Mountains

$1900-01 \ldots \ldots \ldots \ldots \ldots .638 \quad 67 \quad 69$

concolor, $1888-89 \ldots \ldots \ldots$. 4

》 (A. lasiocarpa) 1889-90 $45 \quad 57$

") $\quad 1890-91 \quad 1 \quad 2 \quad 4$

grandis $1890-91 \ldots \ldots \ldots \ldots .26066(+9)$

- $1902-03 \ldots \ldots \ldots . .147(+2)$

magnifica $1901-02 \ldots \ldots \ldots \ldots .32253(+5)$

$\begin{array}{lllllll} & 1906-07 \ldots \ldots \ldots & 0 & 0 & 0 & 58 & 58\end{array}$

D $1909-10 \ldots \ldots \ldots .12$

nobilis, Scottish seed 1902-03 $2 \quad 65 \quad 70$

$49(+15)$

$\begin{array}{lllllll}\text { 1 }>1894-95 & 1 & 4 & 5\end{array}$

i Danish seed 1909-10 $6 \quad 16 \quad 25(+4)$

1) from the Pacific coast

$1905-06 \ldots \ldots \ldots \ldots \ldots .0 . \ldots 12$

nobilis, from the Pacific coast

$1888-89 \ldots \ldots \ldots \ldots \ldots$

religiosa (Mexico) 1909-10

Lot I ................ $19 \quad 38 \quad 44(+1)$

religiosa (Mexico) 1909-10

Lot II................ $120 \quad 28 \quad 30$

subalpina $1904-05 \ldots \ldots \ldots .39 \quad 53 \quad 54(+2)$

\ $\quad 1902-03 \ldots \ldots \ldots 4969$

Abies balsamea is, as far as I know, the only species of Abies that preserves its germinating capacity till the spring of the second year after harvesting. Seed of Danish origin, as well as Danish and Scotch grown seed of Abies nobilis, is much better than seed from the native home of these species in America.

CHAM ECYPARIS LAWSONIANA. In this case also, seed harvested in Danmark is better, larger sized and of higher germinating capacity than that from its native home or from South and Central Europe. The best and worst germination results were as follows: 


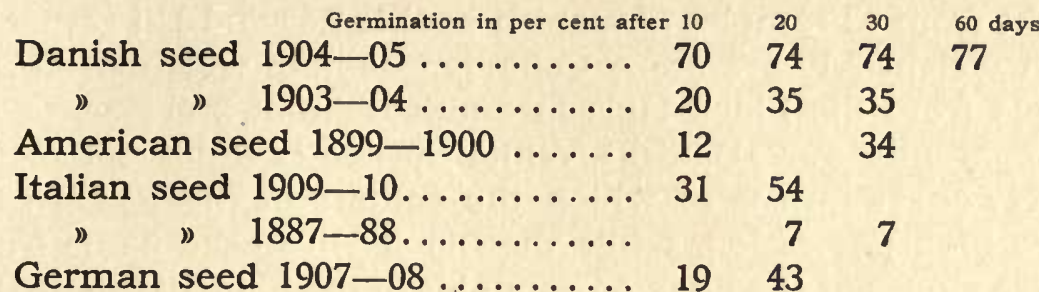

CHAM ECYPARIS NUTKAENSIS. Of this hardy and valuable species I have unfortunately never succeeded in obtaining seed of even moderate quality; as a rule it is quite worthless. Occasionally it germinates one or two per cent - thus:

Danish seed $1889-90 \ldots \ldots \ldots \ldots \ldots . .30$ days $1 \%$

American seed $1899-1900 \ldots \ldots . . .30$, 2 "

Year by year I attempt to get seed of this species from its native home, but without success; so that our only consolation is that this fine Cypress is fairly easily propagated by cuttings or layers.

CUPRESSUS MACROCARPA from California unfortunately always germinates very indifferently: as appears from the Table on p. 68 , the mean real value of the 11 samples over a number of years only amounted to 10.7; highest germinating capacity 23.4, lowest $2.1 \%$.

LARIX AMERICANA and L. OCCIDENTALIS are both seeds difficult to obtain. I have only twice, during the whole twentyfive years, received from Canada, seeds of the East American Tamarack, L. Americana, capable of germination; and in 1912 I saw for the first time seed from the West American species $L$. occidentalis. The seed germinated as follows:

$\begin{array}{ccrrrrr}\text { Germination in per cent after } 5 & 10 & 20 & 30 & 40 \text { days } \\ \text { Larix americana } 1904-05 \ldots & 1 & 5 & 11 & \\ \text { D } & \text { occidentalis } 1911-12 . & 26 & 42 & 50 & 57 & 65\end{array}$

\section{THE AMERICAN SPRUCES - PICEA}

CANADIAN WHITE SPRUCE - PICEA ALBA. As in the case of Abies balsamea, A. nobilis and C. Lawsoniana, Danish seed of this species is also larger and of better germinating capacity than Canadian and American seed. The lowest and highest found seed 


\section{4}

weight from 68 samples of Danish seed is 2.65 and 3.81 respectively; mean weight 3.19 grams. A Canadian sample weighed 2.45 and a sample from the Black Hills in South-Dakota: 2 grams.

Apparently our "Danish" White Spruce is a descendant of the earliest coast forests of which the settlers of the Eastern United States took possession, while the Black Hills seed came from the eastern slopes of the Rocky Mountains in the State of South-Dakota. This is quite sufficient to make a great difference in seed weight, while, in addition, seeds from vigorous artificial woods may often be larger than those from natural forests. The best and worst germination results for the whole period were as follows:

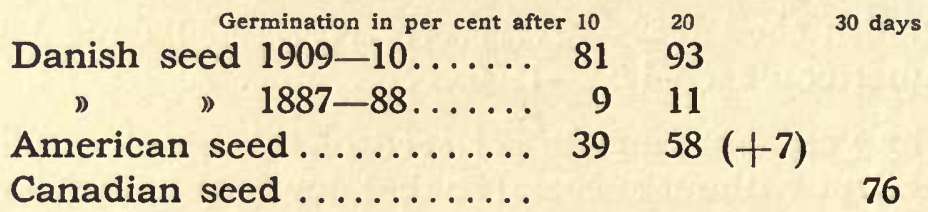

PICEA RUBENS - very similar to Picea alba - has a seed weight of 3.6 grams and germinated $6 \%, 27 \%$ and $32 \%$ in 10 , 20 and 30 days respectively.

PICEA NIGRA belongs to the same group. The mean seed weight is $3.33 \mathrm{gr}$. The best germination result was obtained in the season $1902-03$ with $71 \%$ and $86 \%$ in 10 and 20 days. The lowest germination result was in $1893-94,46 \%$ in 30 days.

The two Rocky Mountain Spruces have always yielded good seed which germinates quickly and easily:

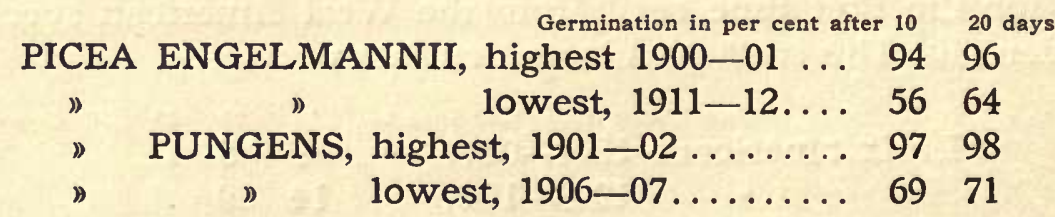

The highest germinating energy in the case of Picea Engelmannii was found in the year 1903-04, when $79 \%$ germinated in 5 days, and in the case of P. pungens, likewise in 1903-04, with $68 \%$ in 5 days.

SITKA SPRUCE - PICEA SITKAËNSIS. In contradistinction to the two spruces from the Rocky Mountains, it is rather difficult to obtain a good germination result with the seed of the Sitka 


\section{5}

Spruce. In itself the seed is good enough; not once since 1902-03 has the quality of the seed been poor. In that year for the first time I received the seed direct from the State of Washington, on the coast of the Pacific, and since then I have obtained it regularly from there. The seed, however, is not easy to bring to germination. It requires a higher temperature, and even then progresses very slowly from the commencement. It was only in the earlier years that some of the seed was bad and impure, a fact that is better brought out if the twenty-five years are divided into two periods: the 15 years from 1887 to 1901 and 10 years from 1902 to 1912.

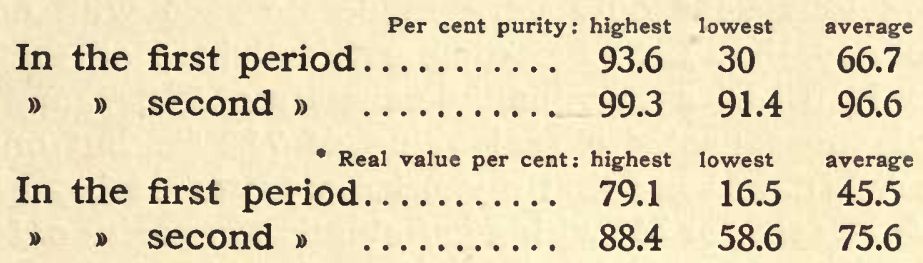

The best and worst germination results were as follows:

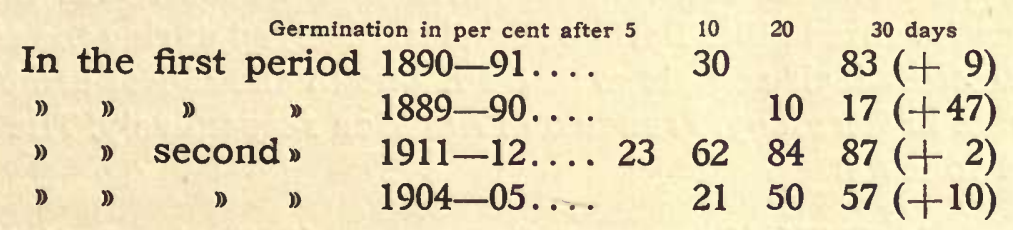

Thus during the last ten years, since 1902, not a single lot of Sitka Spruce seed has had to be rejected; indeed the average real value in the second period might have been even higher than the figures given. It is indeed not an accident that the highest germinating energy and germinating capacity are shown in the last year; but this is the consequence of the continually improving technical skill of the seed-testing Establishment. Nevertheless the valuable Sitka Spruce is, unfortunately, one of those kinds of seeds which often fail in the nursery, simply because this seed, in a particularly high degree, requires a careful soaking and pregermination before sowing.

In 1889-90 I had a small sample of Danish Sitka Spruce seed which germinated $16 \%$ in 15 days and $26 \%$ in 30 days.

For the rest, Sitka Spruce seed in particular is suitable for

* The practical or real value is : purity $\times$ (germinating capacity, plus sound but not yet germinated seeds) 


\section{6}

demonstrating the progress made in the collecting of forest seeds and their treatment during the germinating process, as well as the significance of the fact that the price of the seed varies with its real value, and finally what an immense support the seed tests are to the forest seed trade. I took the opportunity of illustrating this in my two essays: Gehölzsamen-Untersuchungen in der Saison 1902-03 and 1903-04, which appeared in the Transactions of the Deutsche Dendrologische Gesellschaft 1903 and 1904 and in separate reprints. I should like to reproduce here something from them:

In the season 1901-02 we had no Sitka Spruce seed at all and in the previous year only very moderate seed with only $45 \%$ real value, so that I was particularly delighted to find seed in 1902-03 which had a germinating capacity of $79.2 \%$ and a purity of 95 , and consequently a real value of $75.2 \%$. But one of my customers wrote to me that my price was too high, - he could buy plenty of seed for $35 /$ with a germinating capacity of $60 \%$. This was quite true; but $35 /$ for $1 \mathrm{~kg}$ of seed with $60 \%$ germinating capacity, means $58 /$ for $1 \mathrm{~kg}$ of germinating seeds. This induced me to cause three Sitka Spruce samples, received during the season, to be tested. Each sample was from one of the oldest established seedsmen in Germany, France and America respectively. The result was as follows:

Test No. 20736 (Germany) Germ. cap. 68 Real val. $61 \%$

" " 20737 (France) " 20738 (America) $\quad$ " 37 " $\quad$ " $19 \%$

Comparing now the germinating capacity with the prices at which the seed was offered for sale, the following price per $\mathrm{kg}$ of germinating seeds is obtained:

\begin{tabular}{|c|c|c|c|c|}
\hline No & 0736 & $\begin{array}{l}\text { Germinating } \\
\text { capacity } \\
68 \%\end{array}$ & $\begin{array}{c}\text { Price per kg } \\
\text { seed } \\
35.00\end{array}$ & $\begin{array}{c}\text { Price per kg } \\
\text { germinating seed } \\
51.47\end{array}$ \\
\hline 》 & $20737 \ldots$ & $66 \%$ & 37.00 & 56.06 \\
\hline 》 & $20738 \ldots \ldots \ldots \ldots$ & $37 \%$ & 30.30 & 81.89 \\
\hline
\end{tabular}

In the experiment report of the year in question, which was published at the same time, my Sitka seed from the State of Washington proved a germination of $79 \%$, and as the price for $1 \mathrm{~kg}$ of seed was 37.80 , the price for $1 \mathrm{~kg}$ germinating seeds was only 47.85. 


\section{7}

Still more instructive is the $19 \%$ real value of the very impure, so called cheap seed from America, with a cost price of "only" $30.30(30 / 4)$; for the price of $1 \mathrm{~kg}$ of real value was no less than $159.47(159 / 6)$, against which my seed with a germinating capacity of $79 \%$, a real value of 75.2 and a sale price of 37.80 , cost only $50.26(50 / 3)$ per $\mathrm{kg}$ of real value.

In the following year the experiment was repeated, and for this four samples were taken: my own seed as well as samples from two Thuringian firms and one New York one, with the following result:

\begin{tabular}{|c|c|c|c|c|c|}
\hline C & Germinatin & capacity & 80.5 & Real value & $78.57 \%$ \\
\hline II & 》 & ) & 77.5, & D & 73.94 \\
\hline II & 》) & D & 69 & D & 67.76 \\
\hline V & 》) & 》) & 42.5 & D & 36.98 \\
\hline
\end{tabular}

Now as the sale price of the four lots was $34,20,30,34$ and $31.50(31 / 6)$ respectively, the following values are found:

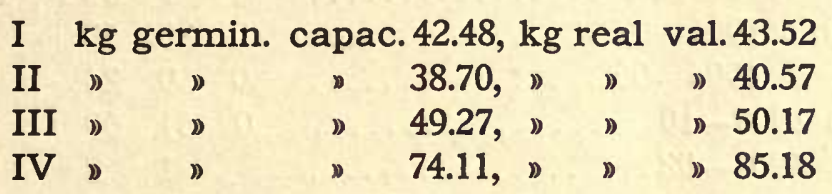

The aim of the future must therefore be to sell seed according to the price per kilog. of real value, and not per kilog. of material. But to carry this through would entail great difficulties. The collectors in America and Japan would not like the price of the seed to be determined here in Europe, two or three months after its dispatch, and the seed merchants in Europe would be unable to issue complete price lists; for the price would be known for the first time, three or four weeks after the many different consignments had been received. In the case of a few of the more important seeds of commerce, such as for example spruce, larch, pine and silver fir seed, which are collected here in Europe and often supplied in large quantities by the kilns, things must be worked so as to avoid discrepancies between the preliminary testing of the seed establishment and the control testing by the purchasers as soon as the technique of the seed testing establishments is sufficiently certain; this might be brought about in the not far distant future. 


\section{8}

\section{AMERICAN PINES - PINUS}

These can be dealt with quite briefly, for none of the American pines are of great importance for Europe. The highest and lowest germinating capacity and germinating energy met with will be alone mentioned.

Pinus aristata 190

Germination in per cent after $\begin{array}{llll}5 & 10 & 20\end{array}$

$1901-02 \ldots \ldots \ldots \ldots \ldots . \quad 98 \quad 99$

$1902-03 \ldots \ldots \ldots \ldots \ldots .68 \quad 81 \quad 87$

Banksiana $1909-10 \ldots \ldots \ldots \ldots .65 \quad 91 \quad 93$

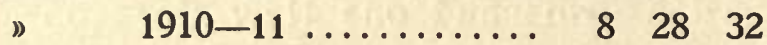

cembroides $1906-07 \ldots \ldots \ldots \ldots . \quad 84 \quad 87$

》 $1901-02 \ldots \ldots \ldots \ldots . .4$

contorta $1909-10 \ldots \ldots \ldots \ldots \ldots .10 \quad 51 \quad 92(+6)$

》 $\quad 1907-08 \ldots \ldots \ldots \ldots .0 .0 \quad 0 \quad 29 \quad 55$

flexilis $1901-02 \ldots \ldots \ldots \ldots \ldots . .6$

》 $1911-12 \ldots \ldots \ldots \ldots \ldots .69 .690$

inops $1906-07 \ldots \ldots \ldots \ldots \ldots \ldots .19 \quad 89 \quad 93$

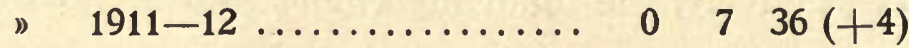

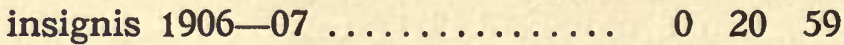

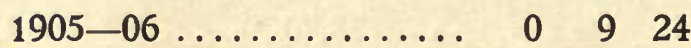

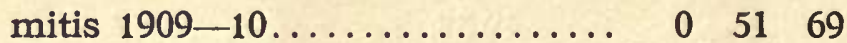

$1901-02 \ldots \ldots \ldots \ldots \ldots . . .13$

Murrayana (Rocky M.) 1901-02 $81 \quad 93$

$\begin{array}{lllll}\text { ") } \quad 1896-97 & 2 & 29\end{array}$

palustris $1911-12 \ldots \ldots \ldots \ldots \ldots . \quad 14 \quad 54$

1908-09 ............ 0 o 1

ponderosa $1910-11 \ldots \ldots \ldots \ldots$.

1) $\quad 1890-91$

resinosa $1905-06$

1902-03

rigida $1905-06$...

,)

1903-04

scopulorum 1906-07

1903-04.
$8896(+1)$

111

9395

$\begin{array}{ll}70 & 89\end{array}$

659396

1848

$21 \quad 9296$

$10 \quad 15$
D

The slow germinating species
Germination in per cent after $10 \quad 20 \quad 30$

Pinus Coulteri 1906 - 07 ..

D, $1908-09$..

D Jeffreyi 1909-10...

" " 1905-06...
30
0
30 days

87

88

14

$68(+3)$

$67(+31)$

$56(+24)$

94

$67(+7)$

$28(+3)$

$69(+22)$

$10(+46)$

$59(+3)$

$2(+5)$

12

$17(+34)$

200 days

$65(+28)$ 


\section{9}

\begin{tabular}{|c|c|c|c|c|c|c|}
\hline Pinu & $\begin{array}{l}\text { Germination in per cent after } \\
\text { Is monticola } 1911-12 \text {. }\end{array}$ & $\begin{array}{rl}10 & 20 \\
& 0\end{array}$ & $0 \quad 30$ & & & 200 days \\
\hline ) & " $1902-03$. & & 02 & & $2(+29)$ & \\
\hline & Nevada $1911-12 \ldots$. & 421 & 131 & 51 & $63(+32)$ & \\
\hline nus & Is Murrayana, Sierra & & & & & \\
\hline & Nevada $1908-09 \ldots$. & 318 & $821(+70)$ & & & \\
\hline nu: & sLambertiana1909-10 & 00 & $\begin{array}{ll}0 & 0\end{array}$ & & 55 & $88(+1)$ \\
\hline 》 & $1908-09$ & & & & 3 & $15(+7)$ \\
\hline ) & Strobus $1905-06 \ldots$ & & & 82 & 95 & \\
\hline 》 & $1896-97 \ldots$ & 1463 & 6 & & & \\
\hline & $1902-03 \ldots$ & & & 10 & $29(+34)$ & \\
\hline
\end{tabular}

The quite extraordinary difference in the germinating energy of Pinus Murrayana from the Rocky Mountains and from the Sierra Nevada is here particularly striking. The seed from the former district has generally almost all germinated after 10 days; the bad result in 1896-97 was fortunately exceptional. On the other hand, the rate of germination of seed from the latter district is very sluggish, for which reason the sowing of this seed in the nursery often fails. As with the other more or less slow germinating species, this seed should either be carefully prepared by steeping and germination before sowing - like Jeffreyi and Strobus -, or prepared for a year before sowing - like Coulteri and Lambertiana.

The variation in seed weight according to the district (place of origin) is often very remarkable. Murrayana seed, for instance, from the Rocky Mountains, has an average weight per 1000 seeds of 4.5 grams - from the Sierra Nevada one of 10.7 .

The same thing is observed with regard to Pinus Monticola seed from north west Idaho, near Canadian border, weighed in 1912 15 grams, while Californian seed weighed 32 grams.

The seed weight of Pinus Jeffreyi (Pinus ponderosa var. Jeffreyi) Pinus ponderosa and Pinus scopulorum (P. ponderosa var. scopulorum) is $125.3,46$ and 30.4 grams respectively.

It is perhaps doubtful if the separation of Pinus ponderosa (seed from the coast of the Pacific) - from the mountain form P. scopulorum - (seed from the Rocky Mountains) - is justified; but in practice it is convenient and safe. Convenient, because all triple names are troublesome; safe, because such easily confused 
names as: Pinus ponderosa var. scopulorum, Pinus ponderosa var. Jeffreyi, Pinus contorta var. Murrayana, Pseudotsuga Douglasii var. glauca, are liable to give rise to inaccuracies. It is not long since seed of Contorta and Murrayana were not distinguished in the market; it was the same with the Green and Blue Douglas Fir. This was, and indeed is, a very simple system for the merchants who deal with seeds like shopkeepers with raisins. It is therefore a great advantage for tree growers to deal with as few varieties and forms as possible. In all cases, where practicable, the limits of the species should be as narrow as possible.

\section{THE DOUGLAS FIR - PSEUDOTSUGA DOUGLASII AND PSEUDOTSUGA GLAUCA}

The difficulty of avoiding clumsy triple names again meets us here. In the first instance I think the difference between the green Coast Douglas and the glaucous or grey Rocky Mountain Douglas is so great, that I am justified in following H. Mayr* in regarding the two as distinct species.

It is indeed possible that the future may show that the boundary between the two species cannot be made a strict one. Seed imported by the Deutsche Dendrologische Gesellschaft from Quesnel, at the source of the Frazer River in British Columbia, produces plants which point in this direction. Apparently they approach the grey form very closely in colour, and the Coast Douglas in rapidity of growth. The future will show if we are here dealing simply with a hybrid between the green and grey species. Unfortunately I have never been able to obtain either seeds or cones of this Quesnel Douglas (Ps. Doug. caesia) for testing; perhaps the seed weight would have shown us something of interest. As may be seen from the Table, the large number of Douglas samples I have submitted for testing during the years have taught us nothing of the influence of the place of origin on the seed weight. 32 Samples of the green species have an average seed weight of 10.3 , and 15 samples of the grey species 11.3 grams. The difference is so small, that it may be owing to the fact that the seed from the Rocky Mountains is generally better cleaned than that from the coast of the Pacific. In the year 1912, for the first time, I received for testing,

* Heinrich Mayr: Fremdländische Wald-und Parkbäume für Europa. 


\section{1}

a sample of exceptionally large Douglas Fir seed from Wenatchee, the eastern slopes of the Cascade Range in the north east part of the State of Washington; a sample which was brought back by a Danish Botanist from a tour in the United States in 1911.

The test gave the following result: Seed weight 15.12 grams, germination $10 \%, 22 \%, 51 \%$ and $63 \%$, in 10,20,30 and 50 days respectively. This not very high germination result makes one suspect defective cleaning; presumably there were many empty seeds present, otherwise the seed weight might have been considerably higher, for the seed was remarkable at first sight for the size of its grains. In the last three years my ordinary trade seed from the State of Washington weighed as follows: 1908-09 11.7, 1909-10 13.9, and 1911-12 10.4 grams. Last year the seed was not as well cleaned as in previous years, as is shown by the seed weight.

Whether the seed of this species from the most southerly part of its range, the Sierra Nevada and the Coast Range of California, is larger than that from northern regions, as generally is the case in other species, I do not precisely know. I can hardly believe so; for in not a single case have the examinations of previous years shown seed of particularly large grains, and it would have been remarkable if, as at that time I was receiving seed through a New York seed dealer, I never once received seed of Californian origin. Since 1902 I have received the seed each year direct from the State of Washington, and the highest seed weight 13.9 was in 1909 - the highest and lowest seed weight in the first 14 years, when the seed was often poorly cleaned, was 12.4 and 7.5 grams.*

When we examine the germination of the Douglas Fir seed, we find a remarkable difference in the germinating capacity and germinating energy of the two species, the green Coast Douglas and the grey Rocky Mountain Douglas; the latter is always the better.

\begin{tabular}{|c|c|c|c|c|}
\hline \multicolumn{2}{|r|}{ ation in 5} & \multirow{2}{*}{$63^{10}-15$} & \multirow{2}{*}{$70-43$} & \multirow{2}{*}{$\begin{array}{l}30 \text { days } \\
76^{30}-50\end{array}$} \\
\hline & $38-$ & & & \\
\hline & Grey species . & $92-70$ & $94-75$ & $94-76$ \\
\hline
\end{tabular}

- After the above statement had been published in the Danish and German editions of this work appeared in Nov, 1912 and Jan. 1913 respectively, I received in March 1913, from a seed collector in California, a small lot of Douglas "from almost due East of San Francisco, altitude $4000-5000$ feet", and found the seed weight to be 22.6 grams and the percentage of seeds capable of germinating $71 \%$ (the germinating capacity was, in 21 days: $31 \%$ and in 56 days: $51 \%$ and $20 \%$ of sound but not yet germinated seeds; the germinating energy was but weak.) The seed weight was accordingly twice as great as the mean weight $(10.3)$ of the whole 32 samples of the green Coast Douglas examined by me in the past 25 years. Hence it would seem that there is after all, a Southern big-grained variety of Douglas, a point which will be further investigated in future years. 


\section{2}

The course of germination in some of the best and worst cases was as follows:

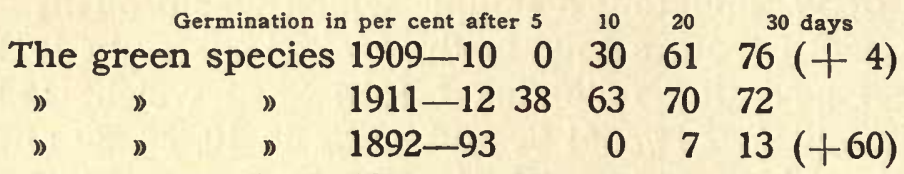

$$
\begin{aligned}
& \text { The grey species I } 1909-10 \quad 75 \quad 92 \quad 94 \\
& \text { » " ॥ II 1909-10 } 18 \quad 29 \quad 32
\end{aligned}
$$

The test result of the green species for 1892-93 does not reflect the real value of the seed, for the result after 30 days - $13 \%$ germinated plus $60 \%$ sound, but not yet germinated seeds - points to the test having been defective. It is not merely an accident, that the two best results with this kind of seed were obtained in the last two years - 1909 and 1911 - , but here again we have evidence of the improving technique of the Seed-testing Establishment. Only once, and that also in the last year, has a good result been obtained with seed of the green species after so little as five days.

Quite otherwise is the behaviour of the grey species. Even after 5 days the germination is as a rule far advanced, and by ten days it is often nearly finished; the bad result of lot II 1909-10 is quite exceptional. If the reports of the Seed testing Establishment on the course of germination, as already noted, were given after 7,14 , 21 instead of $5,10,20$ days, the seed of the Grey Douglas might well be placed among those the examination of which could be brought to a close after 14 days. This would be an advantage to all concerned.

PSEUDOTSUGA MACROCARPA. The seed of this species from southern California, which is not frost-hardy in Danmark, is very much larger grained and slower in germinating than that of the other two species. In 1911-12 I had seed from two different collectors, and the results of the tests were:

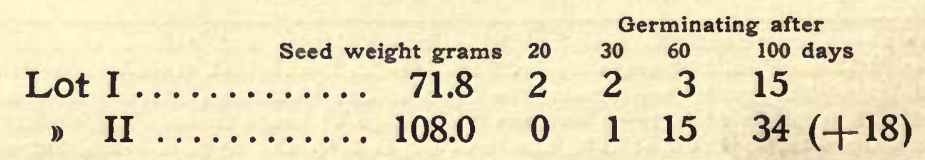

THUYA GIGANTEA. The seed germinated regularly and quickly and is mostly of good quality. Only during the first few years, 


\section{3}

when I didn't yet know how quickly the seed must germinate in order to be good, I had a few bad results. Here are two results with American seed;

$$
\begin{aligned}
& 1909-10 \ldots \ldots \ldots \ldots .10 \text { days } 83,20 \text { days } 91 \% \\
& 1890-91 \ldots \ldots \ldots \ldots 10 \text { " } 0,20 \text { " } 3 \%
\end{aligned}
$$

Danish seed varies greatly, sometimes being good, sometimes poor.

$$
\begin{aligned}
& 1900-01 \ldots \ldots \ldots \ldots .10 \text { days } 80,20 \text { days } 85 \% \\
& 1911-12 \ldots \ldots \ldots .10 \text { \# } 19,20 \text { " } 32 \%
\end{aligned}
$$

\begin{tabular}{|c|c|c|c|c|c|c|}
\hline & & Germinatio & $n$ in per cent afte & & & \\
\hline Canadian & seed & $1909-10$ & ........... & & 75 & \\
\hline ) & w & $1911-12$ & & 0 & 34 & 92 \\
\hline American & seed & $1910-11$ & & 0 & 69 & 85 \\
\hline 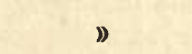 & 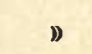 & $1902-03$ & $\ldots$ & & 24 & 41 \\
\hline alian & ) & $1893-94$ & $\ldots \ldots \ldots \ldots$ & & 0 & 42 \\
\hline & 》 & $1889-90$ & $\ldots \ldots \ldots$ & & 0 & 0 \\
\hline $\mathrm{sh}$ & ఎ & $1900-01$ & ......... & & 46 & 78 \\
\hline orwegiar & n & $1909-10$ & ....... & & 77 & 96 \\
\hline
\end{tabular}

THUYA OCCIDENTALIS. Behaves like the last mentioned species:

Among the TSUGAS, TSUGA CANADENSIS, in spite of the smallness and lightness of the seeds, is markedly slow in germinating. I am not yet clear if the seed is really so slow in germinating, or whether it is mostly of bad quality. The best result I have obtained was in the year 1910-11 and was as follows: 30 days $0 \%, 40$ days $20 \%, 60$ days $43 \%, 100$ days $49 \%$; most of the other tests have had a much worse result.

WESTERN HEMLOCK - TSUGA MERTENSIANA. In the case

\begin{tabular}{|c|c|c|c|}
\hline Germination in per cent after 1 & & 30 & \\
\hline $1908-09 \ldots \ldots \ldots \ldots \ldots \ldots$ & 33 & 68 & \\
\hline $1909-10 \ldots \ldots \ldots \ldots \ldots \ldots$ & 20 & 49 & \\
\hline Same lot, 1 year later..... & 10 & 30 & \\
\hline $1910-11 \ldots \ldots \ldots \ldots \ldots \ldots$ & 10 & 24 & \\
\hline Same lot, 1 year later.... & 0 & 9 & \\
\hline $1911-12 \ldots \ldots \ldots \ldots \ldots \ldots 20$ & 46 & $55(+4)$ & \\
\hline
\end{tabular}
of this handsome and valuable species germination proceeds much better, and the seed does not lose its germinating capacity so very quickly. 


\section{4}

TSUGA PATTONIANA. Of this species I have only twice in the whole twenty-five years had good seed; the first time, in 1888 -89 , it germinated only $1 \%$; in $1909-10$, on the other hand, in 10 days $53 \%$, in 20 days $75 \%$ and in 30 days $79 \%$.

Thus the seed is sometimes good; but it is very difficult to obtain.

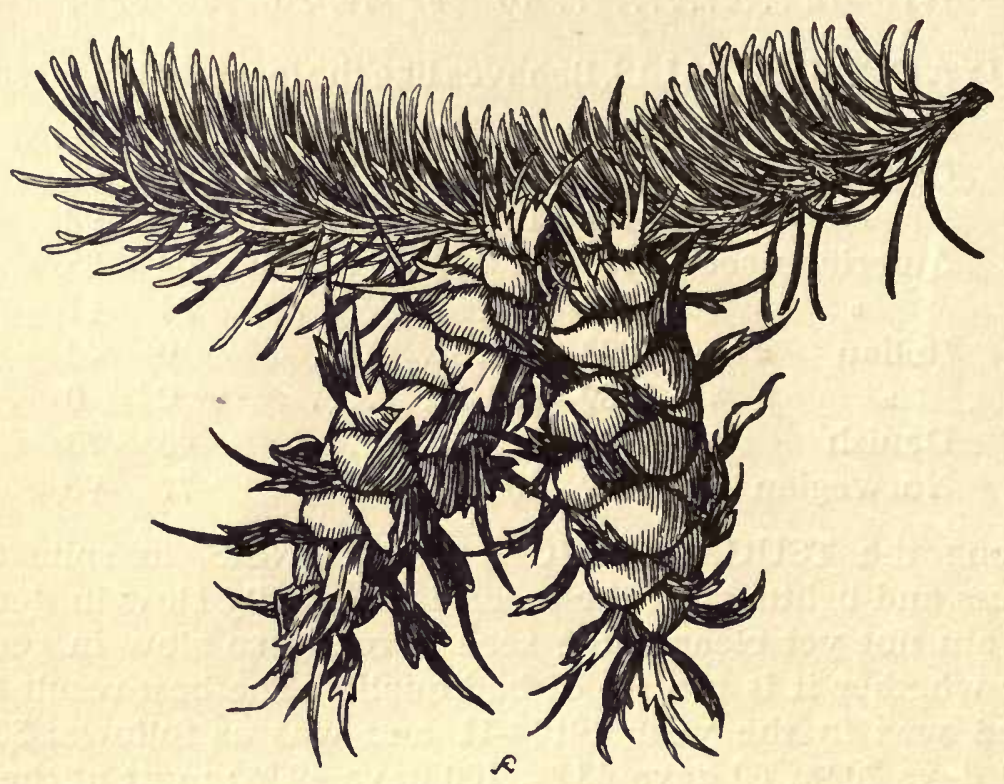



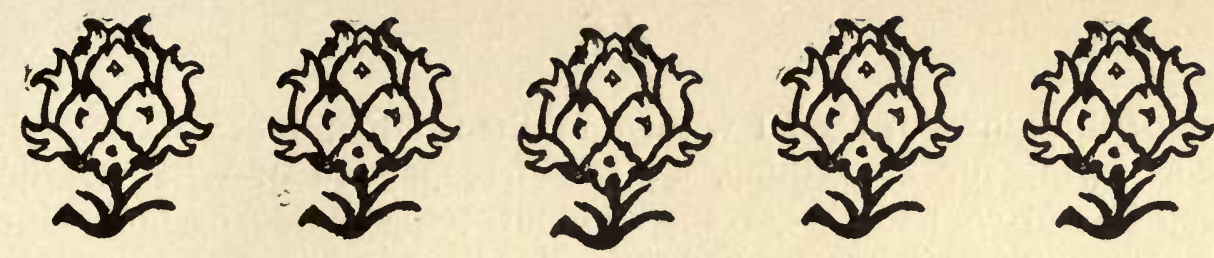

\section{III}

\section{JAPANESE (EAST ASIATIC) CONIFERS}

The Japanese species have always been the troublesome child of the Forest Seed Establishments, and are so still; for even after the lapse of so many years I am not yet so far advanced as to know with confidence the difference between the seeds of all the species of Abies and Pinus, not to mention Picea. For as a rule I receive no Picea seed at all, although year by year I order some of every species. When I do at last receive something, it is so impure and so different in appearance from year to year that there is generally nothing further to be done with it, except to send it out to the nurseries and beg leave to let time show what species it will produce.

However, in the case of some of the Abies species: Abies firma and A. Mariesii, and to a certain extent A. homolepis, I feel on the safe side. But what we receive as A. umbilicata may be sometimes one thing and sometimes another; only twice - 1907 and 1910 - I consider I have certainly succeeded in obtaining the right article, every other time the seed has been either A. firma or A. homolepis.

The seed of Abies Veitchii and A. sachalinensis (A. Veitchii var. sachalinensis) is certainly also sent indiscriminately by the Japanese, so much so that I cannot with certainty distinguish between the seed of the two species.

The same is the case with the seed of Pinus densiflora and P. Thunbergii; each year the outward appearance of the seed received is so different that I am often in doubt about them.

In spite of the fact that I have succeeded in forming some under the circumstances - very good connections in Japan, I cannot get any further with them than just sending each summer a 


\section{6}

list of the kinds of seed I want and then, when these have arrived, paying for everything, entirely irrespective of whether the seed has proved to be correct or incorrect, capable or incapable of germination. It has proved quite hopeless to carry on a written correspondence with these good fellows. In February there arrives an invoice and a consignment which generally includes only half of the goods ordered. Again and again have I sent them samples of their seeds of different years for comparison and asked for an explanation, but I never receive an answer.

One naturally does not expect Japanese or American seed merchants to guarantee the germinating capacity of their seeds. They cannot, because neither in Japan nor in America are there any seed testing Establishments which can be used by business men. On the other hand, the Forest Authorities of these two countries have now got such institutions established for their own use.

In consequence of the above state of affairs, it is not improbable that one or more of us, who may perhaps in another twentyfive years' time take the trouble to accurately test Table III on the seed weight of the Japanese species, may very heavily underline the query which I myself have placed against several species.

Of course there are exceptions: the seed weight of Biota, the Chamæcyparis species, Cryptomeria, Gingkyo, Larix, Pinus koreensis, P. parvifolia, P. pentaphylla, P. pumila, Sciadopitys, Pseudolarix and Thujopsis are given correctly.

It is also not very edifying to inquire too closely into the germination of the seed. Rarely is a good result obtained; on the contrary, the figures are generally poor, as is shown by the averages in the Table. A few species indeed form exceptions, as for example, Biota, the seed of which is chiefly obtained from Italy.

The seed of the two Chamæcyparis species as well as that of Cryptomeria, has, of late years, been often good and often bad:

Germination in per cent after $5 \quad 10 \quad 2030$ days Chamæcyparis obtusa $1911-12$, Lot I.......... $0 \quad 25 \quad 48$

II $\ldots \ldots+\cdots$

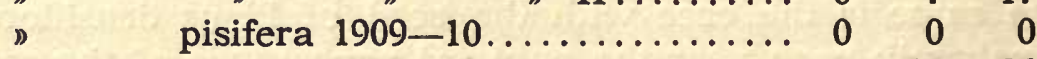

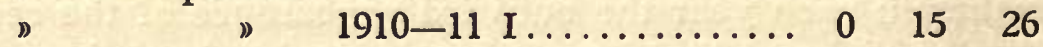

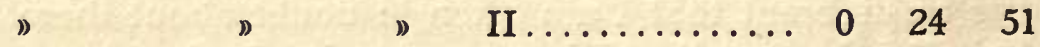

Cryptomeria japonica, Danish Seed $1911-12 \ldots . .0021 \quad 43$

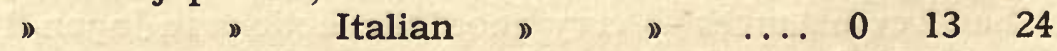

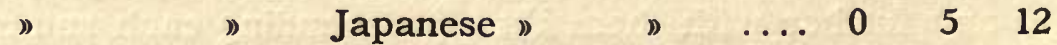




\section{7}

LARIX LEPTOLEPIS. The most important of the Japanese spe cies is naturally the larch.

Even of late years the real value of this seed varies from one extreme to the other, and the Japanese themselves have admitted that the many bad results are to be traced to the too early breaking of the cones. They try to get the earliest possible profit from the cones and in this way destroy the harvest. The tests of the last four years show this.

\begin{tabular}{|c|c|c|c|c|c|c|}
\hline \multicolumn{3}{|c|}{$\begin{array}{c}\text { Germination in per cent after } \\
1907-08 \text { Consignment I . . . }\end{array}$} & 0 & $\begin{array}{c}10 \\
0\end{array}$ & $\begin{array}{r}20 \\
0\end{array}$ & $0^{30}$ days \\
\hline 》) & ) & II ... & 0 & 15 & 65 & \\
\hline ") & 》 & III ... & 0 & 10 & 56 & $67(+1)$ \\
\hline $1908-09$ & .. & ....... & 0 & 0 & 14 & \\
\hline $10-11$ & ig & & 3 & 20 & 48 & 49 \\
\hline " & D & II .... & 0 & 12 & 38 & \\
\hline 》) & ” & III ... & 0 & 5 & 27 & \\
\hline $11-12$ & " & I..... & 0 & 1 & 15 & \\
\hline ) & ) & II. & 0 & 8 & & 29 \\
\hline
\end{tabular}

Such germination results as these cannot, unfortunately, be accepted with satisfaction; but progress is being made. In early years the thoroughly bad consignments appeared even more frequently, and these led to great losses. In January 1906, I received $300 \mathrm{~kg}$. of Japanese larch seed which I paid for on receipt, and 20 days afterwards, learnt by germination tests that the seed was worthless; fortunately this was discovered before it was distributed to the forest nurseries.

The PICEA and PINUS species have often a perfectly satisfactory germinating capacity, if one could, as already said, only guarantee the genuineness of the seed.

The four species: Pinus koreensis, P. parviflora, P. pentaphylla and $P$. pumila, which all belong to the Cembran group and have large hard-shelled seeds, germinate, like the European Cembran pine, very slowly - only after 3-400 days -, consequently the seed must be prepared (stratified) a year before sowing. I have never received seed of Pinus pumila that the Seed-testing Institution could get to germinate.

The seed of PSEUDOLARIX KAEMPFERI is obtainable in Italy, which is a great advantage because it loses its germinating capa- 


\section{8}

city very quickly and can never stand storing from one year to another. If it fails to germinate on occasion, it is because the Italians, when there is a good harvest, store it up for some years. I had particularly fine seed in autumn 1907. It germinated $32 \%$, $65 \%$ and $81(+19) \%$, in 10,20 and 30 days respectively.

The UMBRELLA PINE - SCIADOPITYS VERTICILLATA yields seed which germinates very slowly, in consequence of which it often fails in the nursery; it must be sown very early in a warm bed or in the greenhouse, or be prepared in winter in a warm place and then sown very early in the spring.

As a rule the seed is good and retains its germinating capacity for a long time. In 1909-10 the germination test proceeded as follows: $17 \%, 76 \%$ and $88 \%$, in 40,60 and 100 days respectively.

The handsome THUJOPSIS DOLOBRATA has continually yielded only empty seed. Again and again I have received apparently fine seed from various parts of Japan, always however with the same negative result. The seed is invariably empty. In 1905-06 it germinated 1 per cent, the best result I have had. This species is, therefore, now struck out of my price lists. For the future the only consolation that remains for us is that this fine tree can be fairly easily propagated by means of cuttings or layers.

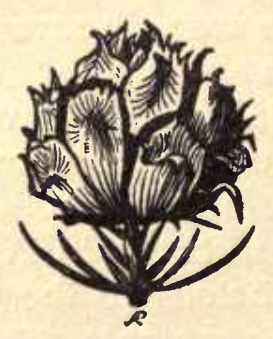




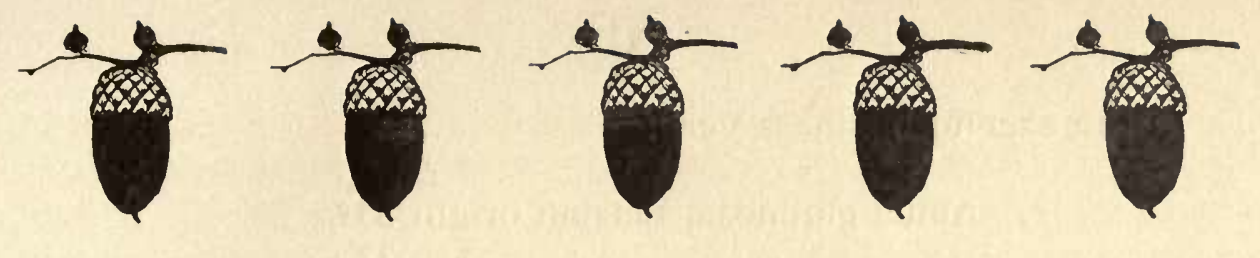

\section{THE SEEDS \\ OF BROAD-LEAVED TREES}

\section{EUROPEAN, NORTH AFRICAN AND WEST ASIATIC SPECIES}

It must be admitted at once that the results obtained from the testing of the seeds of broad-leaved trees are only small compared with those obtained by the testing of conifers.

At the very beginning, 25 years ago, numerous experiments were made, as shown by the two first Reports, covering the business years $1887-88$ and 1888-89. It soon became evident, however, as was generally expected - that these germination tests were for the most part either unsatisfactory or produced no result whatever.

ALNUS and BETULA. As far as the European species are concerned, the Alders and Birches form, indeed, a happy and valuable exception. The germination tests show very quickly and conclusively the real value of these seeds and in this way explain the great uncertainty in their treatment in the nurseries, Particularly in the case of Alder was it a dogma that the seed, to succeed at all, must be sown in autumn, and on this account such early autumn distribution was demanded, that new seed could not be obtained in time. Only after several years' research did this become clear to me.

The germination tests in the very first year 1887-88 gave:

Alnus glutinosa, Belgian origin $1 \%$

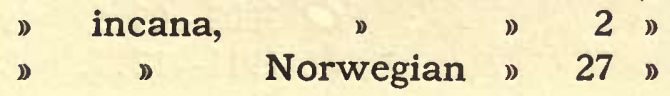




\section{0}

In the second business year:

\begin{tabular}{|c|c|c|c|c|}
\hline Inus & glutinosa, & Belgia & igin & 35 \\
\hline D & 》 & 》 & $D$ & $32 »$ \\
\hline D & incana & D & " & 3 o \\
\hline D & D & 》 & D & 47 ” \\
\hline D & 》 & " & ) & $24 "$ \\
\hline
\end{tabular}

It was important for me to obtain the seed in early autumn, as it was required from me then, and for this reason I received at first year-old worthless seed. Already in the second year, after I had discovered the trickery of the Mid-European seed merchants, it became somewhat better, but I still had many bad germination results for a number of years, so that I was often in doubt if the seed or the seed testing Establishment was at fault. But for about 10 years the Seedntesting Institution has been working, in my opinion, with absolute certitude, so that it is known after a few days if the germination will proceed well and if the lot of seed in question is good enough for use.

ALNUS GLUTINOSA. Whilst the mean germinating capacity over the whole twenty-five years, with 46 samples amounts to $24 \%$, it is $35 \%$ for 19 samples in the last 10 years. The highest germinating capacity during the last ten years is 73 , the lowest $18 \%$.

ALNUS INCANA, Central European seed, gave for 59 tests in the course of 25 years, a mean germinating capacity of $31 \%$, while that for the 20 samples of the last 10 years was $48 \%$, so that we have passed the period of early troubles. The germination now always goes rapidly and smoothly from the start. The best and worse results for the two species have been as follows:

\begin{tabular}{|c|c|c|c|c|c|c|c|c|}
\hline & & & Germir & ation in per cent aft & 5 & 10 & & 30 day \\
\hline Alnus & glutinosa, & Belgian & seed & $1902-03 \ldots$ & 38 & 44 & 4 & \\
\hline$n$ & $"$ & " & " & $1903-04 \ldots$ & 16 & 22 & 25 & 525 \\
\hline 》) & » & D & 》 & $1904-05 \ldots$ & 20 & 25 & 26 & \\
\hline$"$ & 》 & 》 & 》 & $1905-06 \ldots$ & 20 & 23 & $2 \varepsilon$ & 28 \\
\hline " & » & " & " & $1906-07 \ldots$ & 8 & 14 & 16 & \\
\hline 》 & 》 & D & 》 & $1907-08 \ldots$ & 68 & 71 & 73 & \\
\hline ) & 》 & " & " & $1908-09 \ldots$ & 46 & 54 & 56 & \\
\hline 》 & D & D) & D & $1911-12 \ldots$ & 8 & 23 & 30 & \\
\hline
\end{tabular}




\section{1}

Alnus incana Alpine Germination in per cent after $5 \quad 10 \quad 20 \quad 30$ days

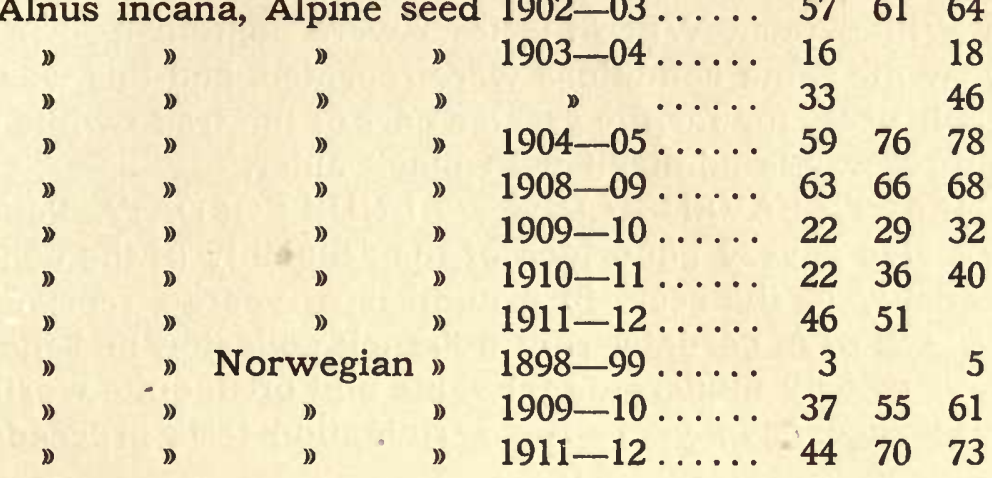

The purity determinations with Alnus incana have provided quite surprising results and shown that this seed is, to a very large extent, adulterated with the always far cheaper seed of Alnus glutinosa.

For this reason I caused in 1903-04 a number of Alnus incana samples that were sent to me, to be tested by the Seed Testing Institution, with the following results:

\begin{tabular}{|c|c|c|c|c|c|c|c|c|c|}
\hline \multirow{2}{*}{\multicolumn{2}{|c|}{ Norwegian }} & \multirow{2}{*}{\multicolumn{2}{|c|}{ Seed ........ }} & \multicolumn{2}{|c|}{$\begin{array}{l}\text { Pure seed } \\
\text { (A. incana) }\end{array}$} & \multicolumn{2}{|c|}{$\begin{array}{l}\text { Foreign seed } \\
\text { (A. glutinosa) }\end{array}$} & \multicolumn{2}{|c|}{$\begin{array}{c}\text { Rubbish } \\
\text { (Shales \&c.) }\end{array}$} \\
\hline & & & & 87 & $\%$ & 0 & $\%$ & 13 & $\%$ \\
\hline & uropes & an Seed & & 57 & ) & 11 & ) & 32 & ) \\
\hline & ) & ) & . & 47 & 》 & 1 & D & 52 & ) \\
\hline & ) & ) & $\ldots \ldots$ & 12 & ) & 25 & 》 & 63 & D \\
\hline pine & Seed & .. & $\ldots \ldots$ & 31 & D & 10 & ) & 59 & 》) \\
\hline 》) & D & & . & 20 & 》) & 10 & ) & 70 & D \\
\hline 》) & D & & $\cdots$ & 25 & D & 4 & 》 & 71 & ) \\
\hline D & D & . & $\ldots \ldots$ & 27 & ) & 19 & 》 & 54 & 》 \\
\hline D & D & - & . & 25 & D & 1 & ) & 74 & 》 \\
\hline D & ) & $\cdots$ & $\ldots$ & 42 & $D$ & 6 & ) & 52 & D \\
\hline D & D & & $\ldots$ & 22 & D & 11 & 》 & 67 & ) \\
\hline 》 & D & & & 47 & 》 & 10 & 》 & 43 & ) \\
\hline D & D & & & 52 & D & 9 & 》 & 39 & $n$ \\
\hline ench & $\mathrm{Se}$ & 4 & 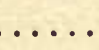 & 13 & 》 & 24 & D & 63 & $》$ \\
\hline
\end{tabular}

Of the whole 14 only the Norwegian sample was quite without admixture of foreign seeds. One Alpine sample was practically speaking pure, while on the other hand the French and one Mid- 


\section{2}

European "White Alder" sample contained twice as much Black Alder as White Alder. When the tests were continued in the following year the same conditions were repeated, and this was confirmed each year, for far the greater part of the trade white alder seed is more or less admixed with black alder.

THE HEART-LEAVED ALDER - ALNUS CORDATA. Repeated tests often give a very good idea of the reliability of the collector and the quality of the seed. In a number of years I received the very rare seed of $\mathrm{A}$. cordata from a French collector, and the seed was always of only moderate real value and often quite worthless.

In three successive years the germination tests proceeded as follows:

$\begin{array}{rrrrrr}\text { Germination in per cent after } 5 & 10 & 30 & 60 & 100 \text { days } \\ 1905 \ldots & 8 & 20 & 30 & & \\ 1906 \ldots & 0 & 8 & 19 & & 56 \\ 1907 \ldots & 0 & 2 & 9 & 12 & \end{array}$

That the seed of each of the three years was furnished from the seed of the same year, is proved especially by the gradually falling germinating energy; indeed the seed was apparently already one year old in 1905, for I received for the first time in the year 1910-11 from an Italian collector a small lot of A. cordata which germinated fast and well and showed what this seed can and ought to be, since the test proceeded as follows: $28 \%, 62 \%, 72 \%$ and $72 \%$, in $5,10,20$ and 30 days respectively.

BIRCH - BETULA VERRUCOSA and BETULA ODORATA. The trade in these seeds has also received much benefit from my cooperation with the Seed Testing Institution. During the earlier years one was pleased with a germinating capacity of $10 \%$ or even less, as the mean germinating capacity of Betula verrucosa amounted in the first 15 years to $16 \%$, in the last 10 years to $29 \%$ and in the last 5 years to $44 \%$.

Of B. ODORATA I have always had only northern seed, of Finnish, Norwegian or Swedish origin, and it was really always of good quality, since the lowest found germinating capacity was $11 \%$ against $2 \%$ for the Mid-European seed, and only 4 out of 23 Scandinavian samples gave but 11 to $15 \%$. The mean germinating capacity for the whole period of years was $37 \%$ against $23 \%$ for the Mid-European seed. 


\section{3}

The course of the germination has been faster and easier during recent years where the seed has been good; this is shown by the following best and worst results obtained:

B. VERRUCOSA, French origin 1908-09... 2 rermination in per cent after 5 r \begin{tabular}{rll}
10 & 20 \\
\hline & 11
\end{tabular}

\begin{tabular}{|c|c|c|c|c|c|c|}
\hline & & & & & & \\
\hline & & & & & & \\
\hline & Da & ") & & 21 & 45 & 48 \\
\hline ") & German & ) & ” & 16 & 33 & 39 \\
\hline " & Danish & ") & $1911-12 .$. & 57 & 84 & 8 \\
\hline ORAT & Norwegian & ” & $1905-06 .$. & 1 & 11 & 7 \\
\hline ” & Swedish & ") & D & 2 & 10 & 2 \\
\hline " & Norwegian & " & 1908-09. & 41 & 48 & 7 \\
\hline " & Swedish & " & $1911-12$. & 46 & 49 & 0 \\
\hline " & Finnish & $D$ & D & 29 & 34 & \\
\hline ") & Norwegian & & $1911-12$. & 15 & 62 & \\
\hline
\end{tabular}

The system hitherto followed by our Danish Seed Testing Institution of reporting the course of the germination at intervals of $5,10,20,30$ days has been excellent and instructive, but, as mentioned before, I think a 7, 14, 21 days period would be a small step forward, and Alnus and Betula would then be among those species the testing of which could be brought to a close after 14 days.

The season 1911-12 gave besides, a good example of how incorrect it is to judge seed only by the price at which it is offered per kilogram. If the prices of the following samples of Birch seed per kilogram germinating capacity and per kilogram real value $\left(\frac{\mathrm{P} \times \mathrm{K}}{100}\right)$ are calculated, the following results are obtained:

\begin{tabular}{|c|c|c|c|c|c|c|}
\hline \multirow{3}{*}{ Danish } & \multirow[b]{2}{*}{$1 .}$. & \multirow{2}{*}{$\begin{array}{c}\text { Purity } \\
36.5\end{array}$} & & \\
\hline & & & 72.0 & 1.35 & 1.88 & 5.13 \\
\hline & II & 34.0 & 80.7 & 1.35 & 1.67 & 4.93 \\
\hline Norwegian & Seed & 30.5 & 66.0 & 1.50 & 2.27 & 7.46 \\
\hline Swedish & ) & 29.5 & 49.7 & 1.20 & 2.42 & 8.16 \\
\hline Dutch & " & 29.0 & 18.7 & 1.00 & 5.35 & 18.52 \\
\hline Thuringian & ) & 19.5 & 9.0 & 1.00 & 11.11 & 55.55 \\
\hline Hessian & D & 25.0 & 4.0 & 1.00 & 25.00 & 100.00 \\
\hline
\end{tabular}




\section{4}

Obviously the three last-mentioned lots were not used; the price mentioned in the calculations is that at which the seed could have been sent out from here.

It is generally considered that Birch seed loses much in germinating capacity during the winter. However, this is not the case, as was shown us by the following experiment during the season 1911-12:

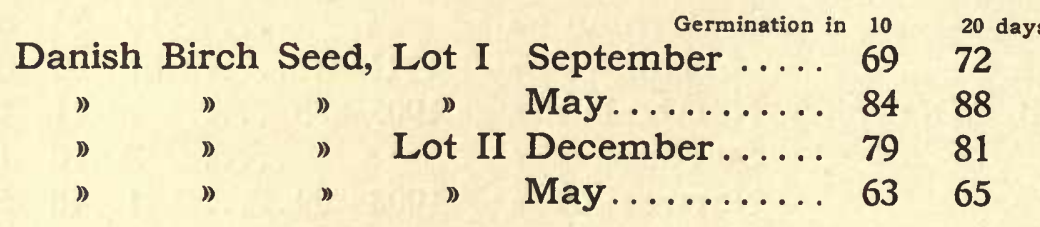

That Lot I germinated better in May than in December is indeed an accident; perhaps it is also to be attributed to the fact that seed ripened by storing sometimes germinates better than freshly gathered seed, which at any rate is nothing extraordinary. The result of Lot II - that the seed fell off somewhat between December and May - would probably be more correct.

\section{ACORNS AND BEECH-NUTS}

With these testing by cutting sections is quite satisfactory, for which reason I have only got the Seed Testing Institution to undertake a few tests, which are set out in Table IV.

On the other hand I have undertaken a series of sowing experiments from time to time with germinated and non-germinated acorns, in order to remove the misgiving, apparent at the time, about sowing germinated acorns; and I have already had the opportunity, in 1900, of demonstrating that acorns germinated before sowing grow just as well as those not germinated.*

A later experiment meanwhile taught that the previously germinated acorns grew not only as well as the non-germinated ones but-under unfavourable conditions - even better.

\footnotetext{
* "Brugbarheden af spirede Agernr. Tidsskrift for Skovvesen, Bind XIII, 1909."
} 


\section{5}

In January 1907, 5 acorn samples each of 100 of the largest and best developed individuals were selected. The samples were mixed with moist turf mould, placed in boxes and stored in an open shed with a roof in my garden. There they remained undisturbed until the sowing took place in 5th May in a shady situation along the north side of some large trees. The soil was moist and cold, deep humus on loam. The summer was cold and rainy. The result was as follows:

Largest Danish ungerminated acorns. 100 weighed 585 gr.

Largest Danish ungerminated acorns. 100 weighed 585 gr.

Largest Dutch. The rootlet just broken out of the shell. 100 weighed $560 \mathrm{gr}$.

Largest Dutch ungerminated. 100 weighed 25 sprouts $585 \mathrm{gr}$.

Largest Dutch with 5-10 cm long black, driedout autumn rootlets, which were cut off to 32 sprouts $1-2 \mathrm{~cm}$ long just before sowing. 100 weighed $585 \mathrm{gr}$.
20. May
20. June
20. July
29. Sept.

1 sprout 19 plants

2 sprouts 12 sprouts 27 plants

7 sprouts 25 sprouts 69 plants 75 plants

9 sprouts 14 sprouts

42 plants 56 plants 80 plants

10 sprouts

68 strong 88 plants 96 plants plants

By "sprout" I mean the young tender, generally red shoot which is visible before the leaves develop, in distinction to the later "plants " bearing leaves. The Danish acorns gave no more plants than noted under 20. Sept., none also in the next summer.

In the same spring in which this small experiment took place I sent to two forest districts in Jutland, each a shipment of acorns of exactly the same lot. In one place the sowing was a complete failure on account of the cold and wet of the summer, whilst in 


\section{6}

the other place a good result was obtained, because these acorns were made to germinate before sowing, by placing them a couple of weeks in a warm stable.

Seedlings of acorns, which have not germinated before sowing, develop a strong tap-root, as is shown in Fig. 1, whilst seedlings from acorns, which have sprouted strongly and whose rootlets are dried up before sowing, form numerous fibrous roots, see Figs. II \& III; the upper black roots are the dried up dead rootlets.

The Figures IV \& V show small Norwegian acorns of Quercus sessiliflora, which during transit in autumn to Danmark became heated in the sack and germinated very strongly, but nevertheless after sowing in the spring grew very well and, instead of the sprouts that had dried up in the winter, developed new roots.
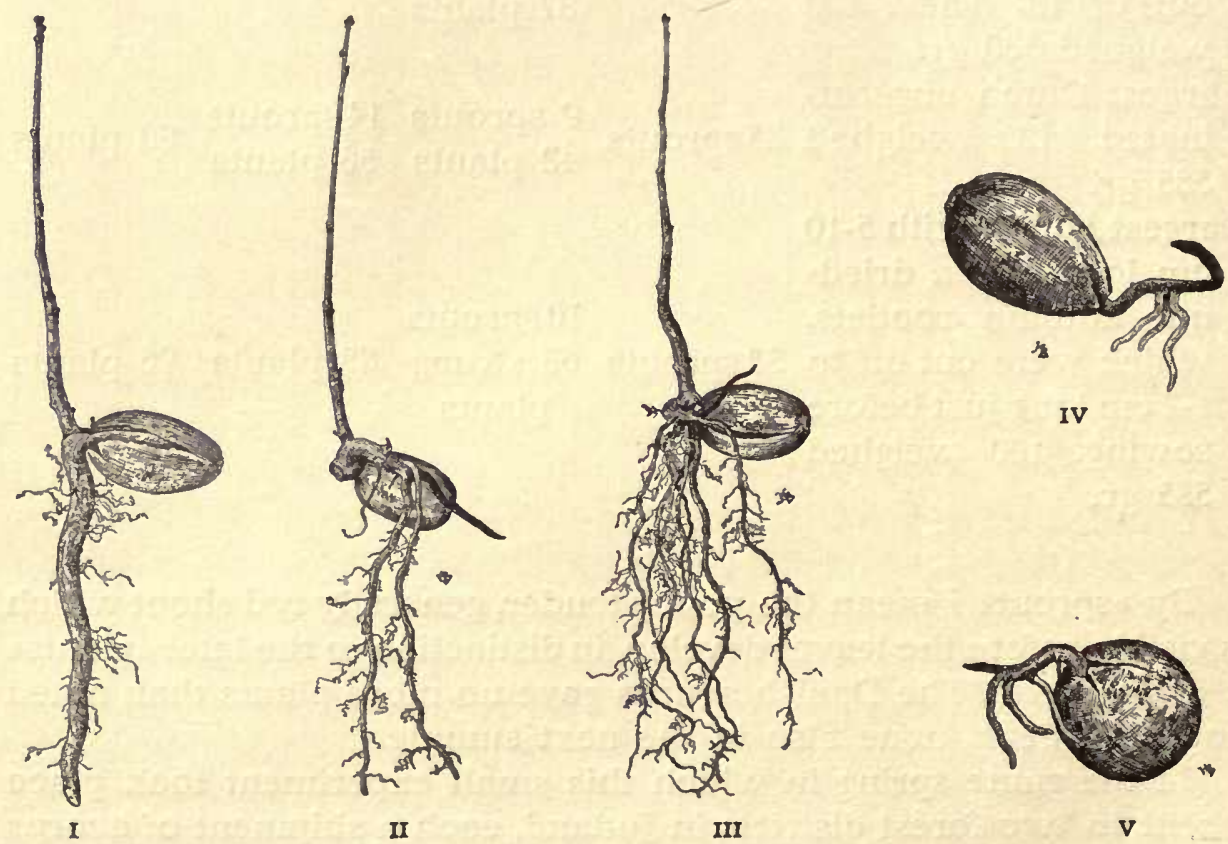
IV

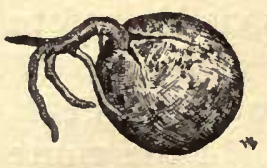

v 


\section{7}

WILLOW-SALIX. As may be known, the seed loses its germinating capacity very rapidly. Already in $1889^{*}$ and $1900^{* *}$ I directed attention to this. A germination test with SALIX CAPREA was carried out in 1888. The seed was collected on 15th June, placed for germination on the 16th and germinated $87 \%$ in 2 days, $93 \%$ in 6 days. 25 days later, the same sample only germinated $7 \%$ in 10 days.

But as I am continually being asked to supply Salix seed, a new test was carried out in 1909.

The seed was collected on June 11th, and was placed for germination the next day, June 12th, and likewise on the 22nd, and 28th June and 5th July, and germinated as follows:

\begin{tabular}{|c|c|c|c|c|c|c|c|}
\hline Germination & test & 12. June: & 2 days & 67 & 10 & day & $72 \%$ \\
\hline 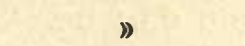 & " & 22. & 》 & 47 & 6 & D & 48 \\
\hline 》 & » & 28. & D & 45 & & & \\
\hline D & " & 5. July & " & 5, & 6 & " & 5 \\
\hline
\end{tabular}

Thus, as in 1888, after 24 days the seed may be said to be worthless. If it is desired to sow Willow seed, it is best to collect it oneself and sow it in a suitable, moist place, without covering the extremely small seed with earth; it will then come up in a few days.

\section{THE AMERICAN BROAD-LEAVED TREES.}

IN TABLE IV we find the same thing, particularly successful germinating tests with only a few species little in demand.

THE BETULA SPECIES mostly germinate quickly and easily, as Table IV shows. Germination tests of the keeping qualities of American birch seed are very instructive. A small lot of BETULA NIGRA which I received from the Arnold Arboretum in summer 1911 and with which a series of tests were at once started, germinated as follows:

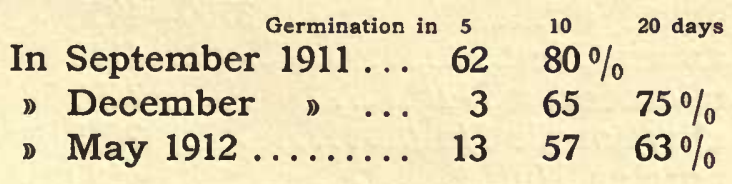

- Analyseresultater for $1888-89$.

** Lidt om Fröanaiysers Betydning for Skovfröeta, Tidsskrift for Skovvæsen, Bind XII, 1900. 


\section{8}

The final germinating capacity thus did not decline seriously from autumn to spring; but the germinating energy in 5 days fell off very significantly.

BETULA PAPYRACEA appears, on the other hand, to lose its germinating capacity more quickly, since two germinating tests in the spring of 1912 with Canadian seed, harvested in 1911, resulted as follows:

\begin{tabular}{llrll} 
February germination $\ldots \ldots \ldots \ldots$ & \multicolumn{1}{c}{5} & \multicolumn{1}{c}{10} & 20 days \\
May germination $\ldots \ldots \ldots \ldots \ldots \ldots$ & 0 & 63 & $67 \%$ \\
& 27 & $34 \%$
\end{tabular}

BETULA LUTEA, likewise of Canadian origin, germinated much more slowly, viz. 5 days $0 ; 10: 25 ; 30: 36.5$, and 80 days $47 \%$.

PLATANUS OCCIDENTALIS serves as a very good example to show of what great use the germination tests can be.

$\begin{array}{crrrrr}\text { Germination in per cent after } 5 & 10 & 20 & 30 \text { days } \\ 1904-05 & \ldots & 50 & 56 & & 56 \\ 1905-06 & \ldots & 0 & 2 & & 4 \\ 1906-07 & \ldots & 46 & 53 & & 58 \\ 1907-08 & \ldots & 0 & 0 & & 0 \\ 1908-09 & \ldots & 1 & 37 & & 54 \\ 1909-10 & \ldots & 46 & 65 & 70 & \\ 1910-11 & \ldots & 2 & 22 & 25 & \end{array}$

According to this, every second year the seed germinates not at all or only very badly, which leads to the conjecture that American collectors only have a good harvest in alternate seasons, when they supply themselves for two years.

CARYA, JUGLANS and QUERCUS. Besides the species which are set forth in Table IV, I have also weighed the following species to find out the number of seeds per kilogram.

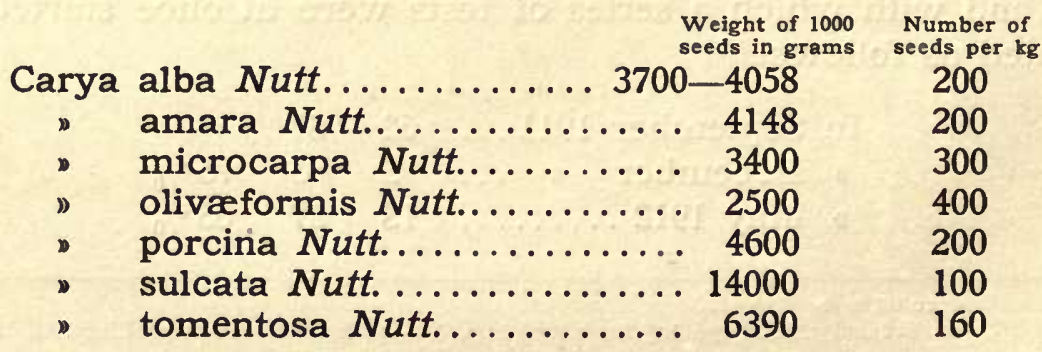




\section{9}

\begin{tabular}{|c|c|c|c|c|}
\hline Juglans & cinerea L., American & seed. & $\begin{array}{l}\text { Weight of } 1000 \\
\text { seeds in grams } \\
\text {. } 12100\end{array}$ & $\begin{array}{c}\text { Number of } \\
\text { seeds per kg } \\
85\end{array}$ \\
\hline ) & nigra $L$. & ) & 20000 & 50 \\
\hline ) & "L. European & ) & 9600 & 100 \\
\hline Quercús & bicolor Willd.... & & 2509 & 386 \\
\hline D & Catesbaei $M c h x . \ldots$ & . & 1150 & 870 \\
\hline 》 & coccinea Wgh... & & 1580 & 630 \\
\hline D & ilicifolia $W g h .$. & & 1017 & 983 \\
\hline D & lyrata Walter..... & & 3473 & 288 \\
\hline D & macrocarpa $M$ chx. & & . 10910 & 92 \\
\hline 》) & palustris Duroi.. & & 920 & 1187 \\
\hline ) & Prinus $L \ldots$ & & 6000 & 170 \\
\hline 》 & rubra L., Ar & seec & 4017 & 224 \\
\hline ) & European see & & 2729 & 400 \\
\hline ) & stellata Wgh... & • & 1020 & 980 \\
\hline
\end{tabular}

QUERCUS RUBRA and JUGLANS NIGRA seed of European origin is much smaller than that from America; the size, however, is very variable. In Table IV - as the result of an earlier weighing - QUERCUS MACROCARPA and Q. PALUSTRIS are given with 300 and 700 seeds to the kilogram. The weight of Q. PEDUNCULATA, Q. CERRIS and Q. CONFERTA are also to be found in Table IV.

\section{THE JAPANESE BROAD-LEAVED TREES.}

The Table of the East Asiatic species offers us little of interest, except that the seed of the splendid BETULA MAXIMOWICZII unfortunately germinates as a rule only from 1 to $11 / 2 \%$. In central Europe this strong, slender tree is found to succeed splendidly on heavy loam soils, and it is much to be desired that the Japanese should soon send us this seed in good quality and at a suitable price. On marshy soils the Japanese Birch succeeds just as little as the American birches.

ACANTHOPANAX RICINIFOLIUM, which some years ago was fairly in demand, has proved unable to germinate in the germinating apparatus, which seems to indicate that, in the beds, it lies over a year in the earth before growing.

CERCIDIPHYLLUM JAPONICUM, on the contrary, sometimes germinates readily and quickly. The best result was as follows: 


\section{0}

5 days 53,10 days 54,20 days 55,30 days $55 \%$. Thus the sample practically had finished its germination after 5 days; generally, however, this seed germinates much more slowly and sometimes not at all.

CATALPA KAEMPFERI, like the American species, C. SPECIOSA and C. BIGNONIOIDES, germinates readily and quickly, and the seed keeps its germinating power for a couple of years. The best result was the following: 5 days $73 \% ; 10$ days $93 \% ; 20$ days $95 \%$; and 30 days $96 \%$; the lowest result: 5 days $9 \% ; 10$ days $83 \%$; 20 days $86 \%$; and 30 days $86 \%$.

PAULOWNIA IMPERIALIS is likewise easy to deal with when the seed is good, which is almost always the case. The best germination result is as under:

5 days $0 \% ; 10$ days $82 \% ; 20$ days $85 \%$; and 30 days $85 \%$; the lowest:

5 days $0 \% ; 10$ days $0 \% ; 20$ days $0 \%$; and 30 days $13 \%$.

WISTARIA CHINENSIS has been tested two or three times, the best germination result being $43 \%$ in 30 days, the lowest only $4 \%$.

ZELKOWA KEAKI, on the contrary, germinates slowly:

10 days $0 \% ; 20$ days $5 \% ; 30$ days $11 \%$; 60 days $29 \%$; and 100 days $43 \%$; consequently in the seed bed the seeds will probably remain a year before growing.

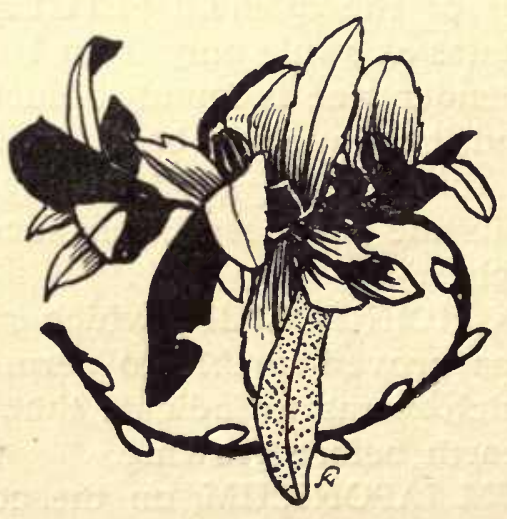




\begin{tabular}{|c|c|c|c|c|c|c|c|}
\hline & & & $\begin{array}{l}\text { Weight } \\
1000 \text { see }\end{array}$ & $\begin{array}{l}\text { No. of seeds } \\
\text { of per kilo oof } \\
\text { ts pure seed }\end{array}$ & & & \\
\hline ucalyptus & amygdalina $1906-07$. & & 0.7 & 1.428 .600 & 42 & 80 & 85 \\
\hline calyptus & amygdalina $1908-09$ & (Crop & & & & & \\
\hline 1904$) \ldots$ & $\ldots \ldots \ldots \ldots \ldots \ldots \ldots \ldots \ldots$ & $\cdots$ & & & 44 & 78 & 90 \\
\hline Icalyptus & amygdalina $1908-09$ & (Crop & & & & & \\
\hline 1906)... & 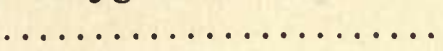 & & & & 20 & 62 & 85 \\
\hline caly! & amygdalina $1910-11$ & (Crop & & & & & \\
\hline 19 & $\ldots \ldots \ldots \ldots \ldots$ & & & & 40 & 84 & 89 \\
\hline aly & gigantea $1908-09$ (Crop & p 1904) & & & 46 & 71 & 87 \\
\hline 》 & $1910-11()$ & 1909) & 1.0 & 1.000 .000 & 13 & 72 & 85 \\
\hline 》 & globulus $1908-09$ ( ) & 1904) & & & 91 & 91 & 94 \\
\hline ") & $1908-09$ ( ) & 1907) & & & 69 & 75 & 78 \\
\hline " & $1910-11 \ldots$. & $\ldots \ldots$ & 2.3 & 434.800 & 86 & 94 & 96 \\
\hline ") & Gunnii 1908-09 (Crop & 1904) & & & 60 & 79 & 80 \\
\hline ") & $1910-11(")$ & 1909) & 0.6 & 1.6 & 61 & 93 & 94 \\
\hline ) & Stuartiana $1910-11$ & 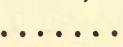 & 0.6 & 1.666 .700 & 93 & 96 & 96 \\
\hline
\end{tabular}

The extraordinary keeping power of the seed is striking. Consider, for example, E. amygdalina: seed of the 1904 crop germinated $90 \%$ even after 4 years, and the same is the case with $\mathrm{E}$. gigantea, E. globulus and E. Gunnii. The seed weight as well as the number of seeds per kilogram refers here, as everywhere, only to the pure seed, not to the real value; for Eucalyptus seed is very often impure, since it contains a great deal of the remains of the fruit capsules as with Alder and Birch seed, so that seed with 70,80 to $90 \%$ germinating capacity has usually only a real value of $15-20 \%$.

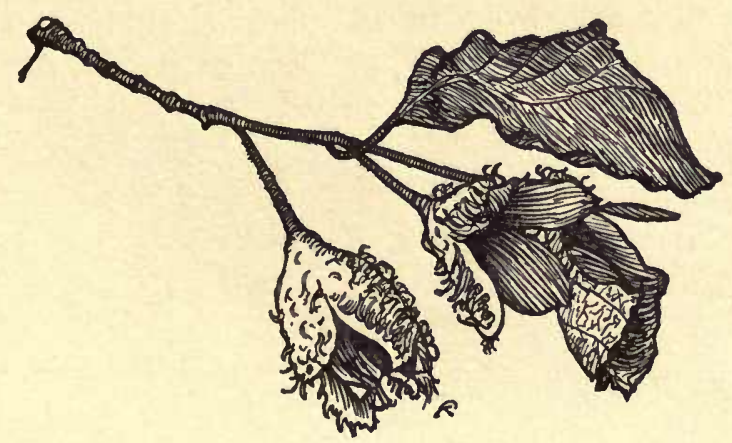





\section{TABLE \\ I}

\section{CONIFEROUS TREE SEEDS}

EUROPEAN, WEST-ASIATIC AND NORTH-AFRICAN SPECIES
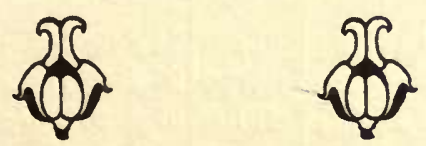

AVERAGE FIGURES FOR 25 YEARS 


\section{4}

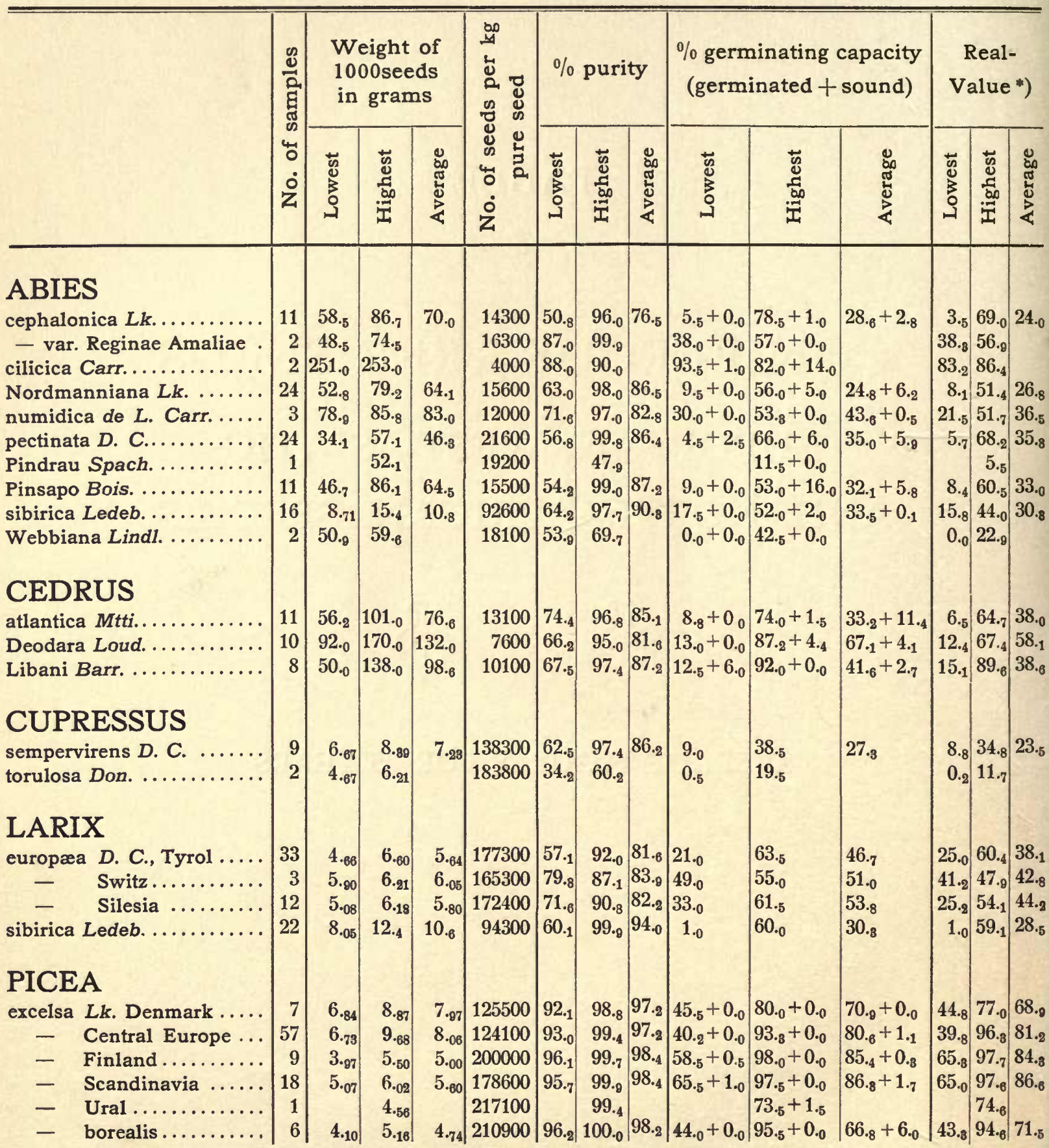




\section{5}

The course of germination

\begin{tabular}{|c|c|c|c|c|c|c|c|c|c|c|c|c|c|c|c|c|c|}
\hline \multicolumn{3}{|c|}{$\begin{array}{l}5 \text { days } \\
\%\end{array}$} & \multicolumn{3}{|c|}{$\begin{array}{l}10 \text { days } \\
\% \%\end{array}$} & \multicolumn{3}{|c|}{$\begin{array}{l}20 \text { days } \\
\% \%\end{array}$} & \multicolumn{3}{|c|}{$\begin{array}{c}30 \text { days } \\
\%\end{array}$} & \multicolumn{3}{|c|}{$\begin{array}{l}60 \text { days } \\
\%\end{array}$} & \multicolumn{3}{|c|}{$\begin{array}{c}100 \text { days } \\
\%\end{array}$} \\
\hline 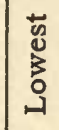 & 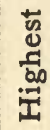 & 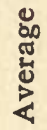 & 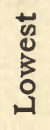 & 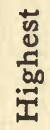 & 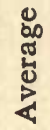 & 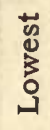 & 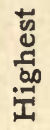 & 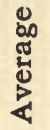 & 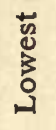 & 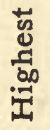 & 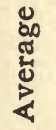 & $\begin{array}{l}\text { 范 } \\
\vdots \\
0 \\
0\end{array}$ & 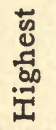 & 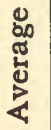 & 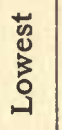 & 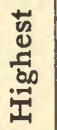 & 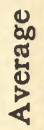 \\
\hline
\end{tabular}

\section{ABIES}

cephalonica $L k \ldots \ldots \ldots$. . - var. Reginae Amaliae. . cilicica Carr.............. Nordmanniana $L k . \ldots \ldots$ numidica de $L$. Carr...... pectinata D.C...........

Pindrau Spach...........

Pinsapo Bois. ............ sibirica Ledeb............ $0_{\cdot 8} \quad 7_{.0}$ Webbiana Lindl. ..........

\section{CEDRUS}

atlantica $M t t i . \ldots \ldots \ldots$. .

Deodara Loud. ...........

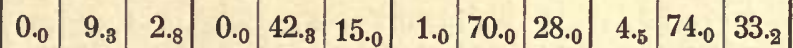

Libani Barr

\begin{tabular}{lllllllllllllll}
0.0 & 12.0 & 4.4 & 0.0 & 27.5 & 12.8 & 13.0 & 67.0 & 42.8 & 13.0 & 87.2 & 67.1 \\
\hline
\end{tabular}

\section{CUPRESSUS}

sempervirens $D$. C......... 0 .

\begin{tabular}{ll|l|l|} 
&
\end{tabular}

\section{LARIX}

europaea $D . C .$, Tyrol ..... 0.0 .034 .7

- Switzerland......

Silesia........... 0.0 .032$.

sibirica Ledeb...........

\section{PICEA}

excelsa $L k$. Denmark .....

$\begin{array}{lllllllllllllll}0.0 & 5.3 & 1.5 & 3.0 & 51.0 & 16.5 & 0.5 & 73.0 & 21.1 & 3.5 & 78.5\end{array}$

\begin{tabular}{ll|l|l|l|l|l}
2.5 & 4.5 & & & 38.0 \\
0.0 & 0.5 & 0.0 & 25.5
\end{tabular}

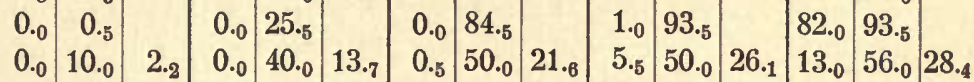

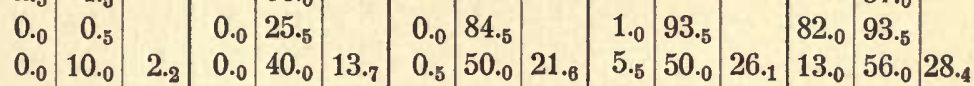

57.0

$\begin{array}{llllllllllllll}0.0 & 4.7 & 2.1 & 0.0 & 18.5 & 9.3 & 2.0 & 53.8 & 31.9 & 17.0 & 53.3 & 39.3\end{array}$

\begin{tabular}{ll|l|l|l|l|l|l|l|l|l|l|l}
0.0 & 27.7 & 12.9 & 2.3 & 63.5 & 28.1 & 4.5 & 66.0 & 32.8 & 71.0
\end{tabular}

\begin{tabular}{r|r|r|r|r|r|r|r|r|r|} 
& 3.5 & & & 11.5 & & & 11.5 & \\
0.0 & 20.0 & 4.0 & 5.0 & 35.0 & 21.5 & 9.0 & $55_{.5}$ & 32.1
\end{tabular}

\begin{tabular}{r|r|r|r|r|r|r|r|r|r|}
3.0 & 37.8 & 22.7 & 12.0 & 47.0 & 30.3 & 17.5 & 52.0 & 32.8
\end{tabular}

\begin{tabular}{ll|l|l|l|l|l|l|l|l|l|l|l|l|l|l}
0.0 & 9.5 & 0.0 & 40.0 & 0.0 & 42.5
\end{tabular}

\begin{tabular}{|l|l|l|l|l|l|l|l|l|}
3.5 & 24.8 & 11.9 & 8.7 & 42.0 & 23.8 & 9.5 & 92.0 & 41.6 \\
\hline
\end{tabular}

$\begin{array}{llllllllllll}2.3 & 14.5 & 8.2 & 7.5 & 38.5 & 26.5 & 9.0 & 38_{.5} & 27.3\end{array}$

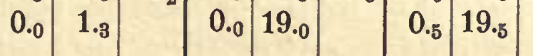

$\begin{array}{lllllllllll}4.3 & 57.0 & 31.9 & 21.0 & 60.0 & 41.7 & 21.0 & 63.5 & 46.7\end{array}$ \begin{tabular}{lll|l|l|l|l|l|l|l|l}
21.3 & 33.0 & 27.0 & & 49.0 & 55.0 & 51.0
\end{tabular}

$\begin{array}{llllllllll}2.2 & 50.5 & 27.4 & 33_{.0} & 58.0 & 50.7 & 33_{0} & 61.5 & 53.8\end{array}$

$\begin{array}{llllllllll}0.7 & 50.2 & 20.1 & 1.0 & 55.0 & 29.5 & 1.0 & 60.0 & 30.8\end{array}$

- Central Europe...

- Finland .......... 0

- Scandinavia............. 0.7

- Ural .................. 19

- borealis..........

\begin{tabular}{|l|l|l|l|l|l|l|l|l|l|l}
$56_{.3}$ & 95.0 & 83.1 & 65.5 & 97.5 & $86_{.2}$ & $65_{.5}$ & $97_{5}$ & $86_{.8}$ \\
\hline
\end{tabular} 67.7

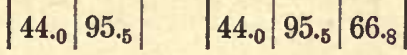




\section{6}

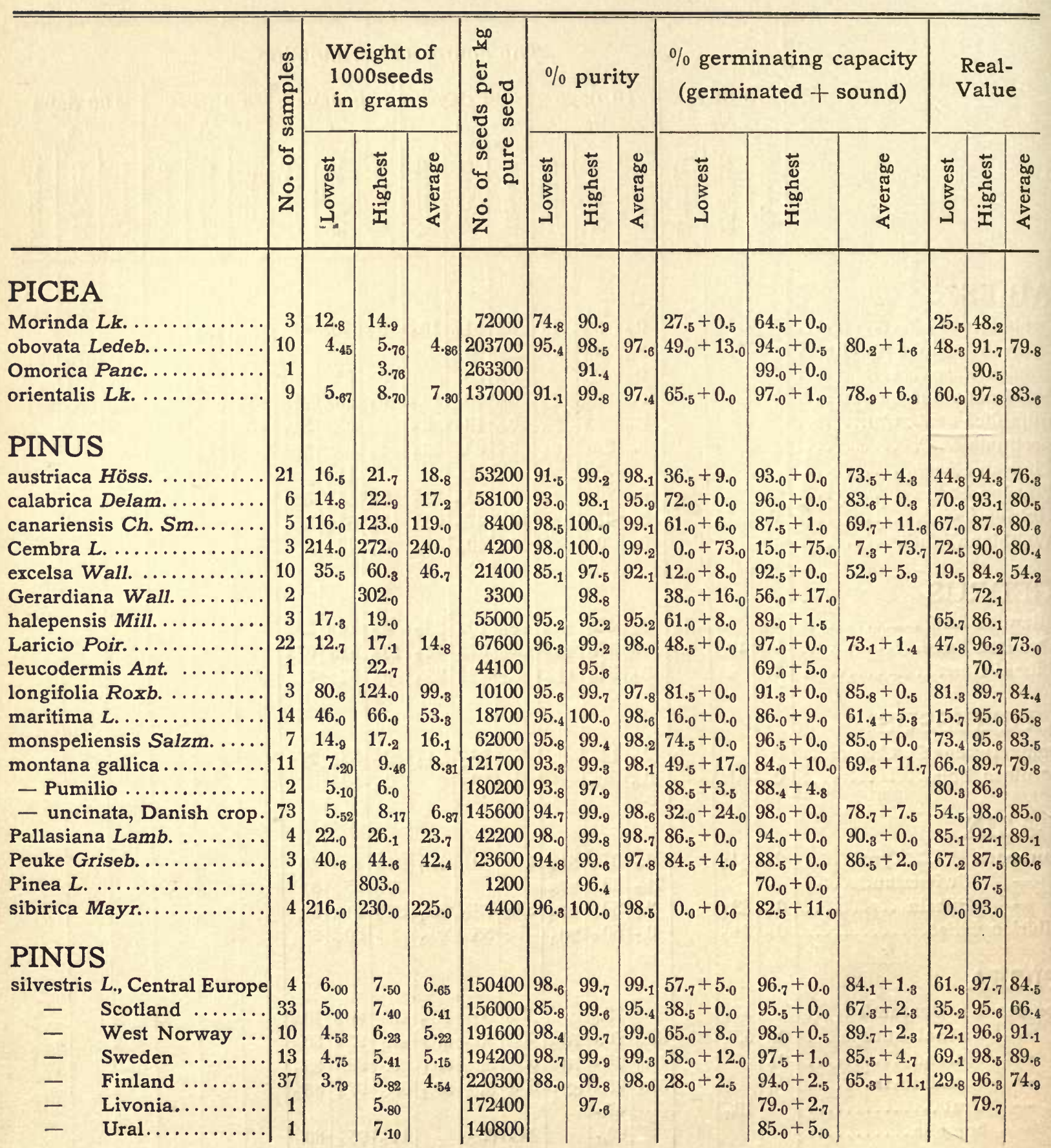


The course of germination

\begin{tabular}{|c|c|c|c|c|c|c|c|c|c|c|c|c|c|c|c|c|c|}
\hline \multicolumn{3}{|c|}{$\begin{array}{l}5 \text { days } \\
\%\end{array}$} & \multicolumn{3}{|c|}{$\begin{array}{l}10 \text { days } \\
\% \%\end{array}$} & \multicolumn{3}{|c|}{$\begin{array}{c}20 \text { days } \\
\%\end{array}$} & \multicolumn{3}{|c|}{$\begin{array}{c}30 \text { days } \\
\%\end{array}$} & \multicolumn{3}{|c|}{$\begin{array}{c}60 \text { days } \\
\%\end{array}$} & \multicolumn{3}{|c|}{$\begin{array}{c}100 \text { days } \\
\%\end{array}$} \\
\hline 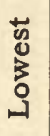 & 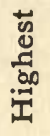 & 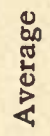 & 荡 & 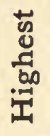 & $\begin{array}{l}0 \\
0 \\
5 \\
5 \\
5\end{array}$ & 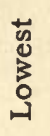 & 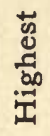 & $\begin{array}{l}0 \\
0 \\
0 \\
0 \\
0 \\
0 \\
\end{array}$ & 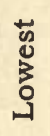 & $\begin{array}{l}\text { 苍 } \\
\frac{d}{00} \\
\text { 空 }\end{array}$ & 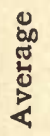 & $\begin{array}{l}\text { 范 } \\
0 \\
0\end{array}$ & 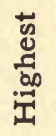 & 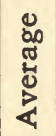 & 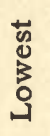 & 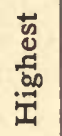 & 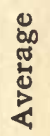 \\
\hline
\end{tabular}

\section{PICEA}

Morinda $L k$. . . . . . . . . obovata Ledeb............ Omorica Panc............ orientalis $L k$. . . . . . . 0

\section{PINUS}

austriaca Höss.

canariensis $\mathrm{Ch} . \mathrm{Sm} . . . .$.

Cembra L.............

excelsa Wall...........

Gerardiana Wall. .......

halepensis Mill. ........

Laricio Poir. .............

leucodermis Ant. ........

longifolia $\operatorname{Roxb.........~}$

maritima $L . . \ldots \ldots \ldots \ldots \ldots$

monspeliensis Salzm. ....

montana gallica..........

- Pumilio

- uncinata, Danish crop.

Pallasiana Lamb. ........

Peuke Griseb...........

Pinea $L . \ldots \ldots \ldots \ldots \ldots \ldots$

sibirica Mayr. .........

\section{PINUS}

silvestris $L$., Central Europe

- Scotland........

- West Norway ...

- Sweden ........

- Finland ........

- Livonia..........

$-$ \begin{tabular}{r|r|r|r|r|}
0.0 & 0.0 & 0.0 & 0.0 & 61.3 \\
0.0 & 70.8
\end{tabular}$\quad \begin{array}{rl}28.7 & 92.0\end{array}$

0.0

0.770 .7 \begin{tabular}{|l|l|l|l|l|l|l|l|l|}
21.3 & 86.8 & 62.1 & 36.5 & 92.5 & 73.0 & 36.5 & 93.0 & 73.5
\end{tabular} \begin{tabular}{lllll|l|l|l|l|l|l|l|l|}
16.3 & 75.0 & 40.5 & 59.7 & 93.0 & 77.3 & 72.0 & 96.0 & 83.6 & 72.0 & 96.0 & 83.6
\end{tabular} 0.0 \begin{tabular}{lll|l|l|l|l|l|l}
2.8 & 58.0 & 31.5 & 33.0 & 85.5 & 65.2 & 44.6 & 87.5 & 69.7
\end{tabular} \begin{tabular}{r|r|r|r|r|r|r|}
\hline 0.0 & 11.0 & 6.0 & 0.0 & 15.0 & 7.3 \\
\hline
\end{tabular}

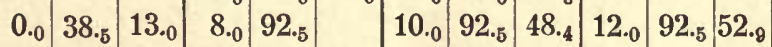
\begin{tabular}{ll|l|l|l|l|l|l|l|l}
4.0 & 14.0 & 38.0 & 48.0
\end{tabular} \begin{tabular}{r|r|r|r|r|r|r|r|r|r|}
\hline 7.7 & 1.0 & 17.0 & & 31.7 & 78.0 & & 61.0 & 89.0 & \\
20.0 & 94.8 & 60.0 & 48.0 & 97.0 & 72.1 & 48.5 & 97.0 & 73.1
\end{tabular} 1.0 2.0 \begin{tabular}{r|r|r|r|r|r|r|r|r|}
73.5 & $\begin{array}{r}1.0 \\
88.0\end{array}$ & 79.0 & 81.5 & 91.3 & 85.8 & 81.5 & 91,3 & 85.8
\end{tabular} \begin{tabular}{l|l|l|l|l|l|l|l|l|l|l|l|}
0.0 & 0.0 & 0.0 & 0.0 & 35.0 & 11.7 & 11.0 & 80.0 & 49.7 & 16.0 & 88.7 & 61.4 \\
\hline
\end{tabular} \begin{tabular}{l|l|l|l|l|l|l|l|l|}
7.0 & 68.0 & 52.7 & 41.7 & 90.3 & 75.9 & 73.5 & 91.5 & 85.0 \\
\hline
\end{tabular} \begin{tabular}{llll|l|l|l|l|l|l|}
1.7 & 48.0 & 30.6 & 37.3 & 77.7 & 58.3 & 49.5 & 87.0 & 69.5 \\
\hline
\end{tabular}

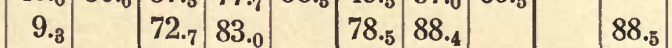
\begin{tabular}{l|l|l|l|l|l|l|l|l|l|l|l|}
1.3 & 87.0 & 35.2 & 19.0 & 95.7 & 63.6 & 32.0 & 98.0 & 75.0 & 32.0 & 98.0 & 78.7 \\
\hline
\end{tabular} \begin{tabular}{|l|l|l|l|l|l|l|l|l|l|}
\hline 47.7 & 43.0 & 87.0 & 68.1 & 86.0 & 94.0 & 89.7 & 86.5 & 94.0 & 90.3 \\
\hline
\end{tabular} \begin{tabular}{l|lllllll}
0.0 & 0.8 & 0.2 & 0.0 & 1.3 & 0.8 & 0.0 & 11.3
\end{tabular}

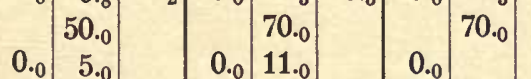
\begin{tabular}{l|l|l|l|l|l|l|l|l|}
9.3 & 63.0 & 45.5 & 46.0 & 90.0 & 77.6 & 57.7 & 96.7 & 84.1
\end{tabular} \begin{tabular}{l|l|l|l|l|l|l|l|l|l|l|}
3.7 & 43.0 & 25.0 & 83.0 & 52.8 & 38.5 & 94.0 & 65.8 & 38.5 & 95.5 & 67.3
\end{tabular} \begin{tabular}{|l|l|l|l|l|l|l|l|l|l|l|l|}
5.3 & 83.0 & 48.1 & 54.3 & 94.7 & 84.5 & 64.0 & 98.0 & 89.4 & 65.0 & 98.0 & 89.7
\end{tabular} \begin{tabular}{l|l|l|l|l|l|l|l|l|l|}
51.3 & 40.0 & 90.7 & 71.2 & 58.0 & 97.5 & 85.2 & 58.0 & 97.5 & 85.5
\end{tabular} \begin{tabular}{|l|l|l|l|l|l|l|l|l|l|l|l|}
6.7 & 57.0 & 23.7 & 7.6 & 91.8 & 52.1 & 11.5 & 94.5 & 61.5 & 15.0 & 94.5 & 65.3 \\
\hline
\end{tabular} 40.3 15.7

$\left|\begin{array}{l}70.3 \\ 66.7\end{array}\right|$




\section{TABLE II}

\section{AMERICAN CONIFERS}
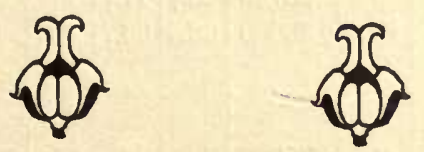

AVERAGE FIGURES FOR 25 YEARS 


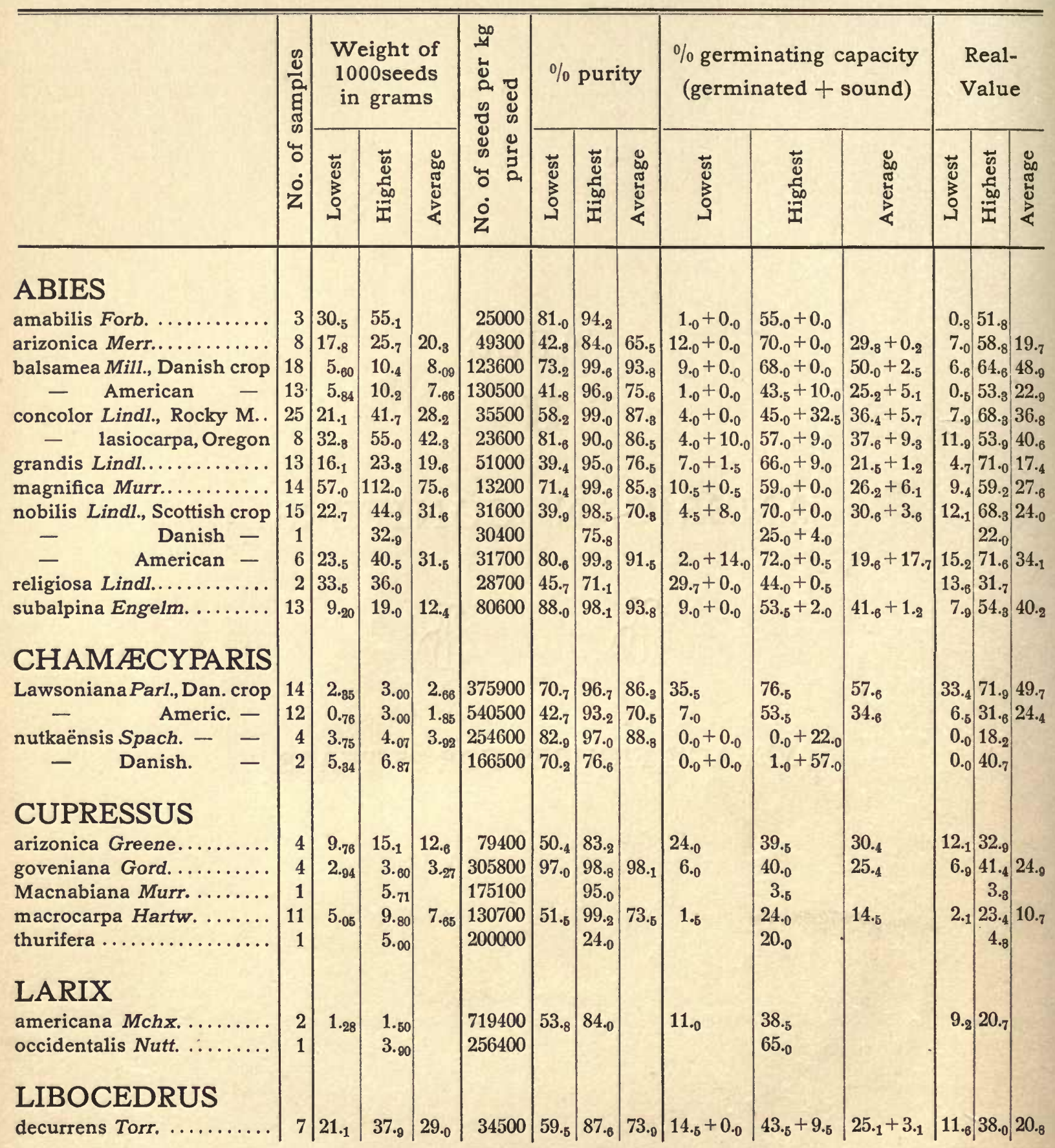


The course of germination

\begin{tabular}{|c|c|c|c|c|c|c|c|c|c|c|c|c|c|c|c|c|c|c|c|c|}
\hline \multicolumn{3}{|c|}{$\begin{array}{l}5 \text { days } \\
\%\end{array}$} & \multicolumn{3}{|c|}{$\begin{array}{c}10 \text { days } \\
\%\end{array}$} & \multicolumn{3}{|c|}{$\begin{array}{c}20 \text { days } \\
\%\end{array}$} & \multicolumn{3}{|c|}{$\begin{array}{c}30 \text { days } \\
\%\end{array}$} & \multicolumn{3}{|c|}{$\begin{array}{c}60 \text { days } \\
\%\end{array}$} & \multicolumn{3}{|c|}{$\begin{array}{c}100 \text { days } \\
\%\end{array}$} & \multicolumn{3}{|c|}{$\begin{array}{c}\text { over } 100 \\
\text { days } \%\end{array}$} \\
\hline 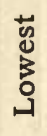 & $\frac{\vec{y}}{d 0}$ & 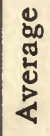 & $\begin{array}{l}\text { 荡 } \\
\vdots \\
\vdots\end{array}$ & 苞 & ฐ্ & $\begin{array}{l}\text { 范 } \\
0 \\
\vdots \\
0\end{array}$ & & $\widetilde{\sigma}$ & $\overrightarrow{\mathrm{s}}$ & 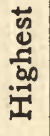 & $\begin{array}{l}\text { 品 } \\
\text { đ్ } \\
\text { d }\end{array}$ & 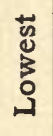 & 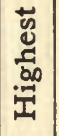 & $\begin{array}{l}0 \\
0 \\
0 \\
0 \\
0\end{array}$ & $\begin{array}{l}\text { 范 } \\
\vdots \\
\text { 号 } \\
\end{array}$ & 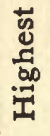 & $\begin{array}{l}\text { 品 } \\
\text { 蛋 }\end{array}$ & 范 & 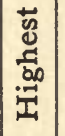 & $a$ \\
\hline
\end{tabular}

\section{ABIES}

amabilis Forb. ........... arizonica Merr........... $1.36{ }^{3}$ balsamea Mill., Danish crop American concolor Lindl., Rocky M. . - lasiocarpa, Oregon grandis Lindl............. magnifica Murr........... nobilis Lindl. Scotch crop. -
$-\quad \begin{array}{r}\text { Danish } \\ \text { american }-\end{array}$
religiosa Lindl............
subalpina Engelm........

\section{CHAM ECYPARIS}

Lawsoniana Parl. Dan. crop - American nutkaënsis Spach. - Danish -

\section{CUPRESSUS}

arizonica Greene.......... goveniana Gord. ..........

Macnabiana Murr. ........ macrocarpa Hartw........ thurifera

\section{LARIX}

americana $M c h x . . . . . . .$. occidentalis Nutt. ........

\section{LIBOCEDRUS}

\begin{tabular}{|r|r|r|r|r|r|r|r|r|r|r|r|}
\hline 0.0 & 0.0 & 0.0 & 16.0 & 70.0 & 36.1 & 35.0 & 74.0 & 52.8 & 35.5 & 74.8 & 57.4 \\
0.0 & & & 1.0 & 30.7 & 15.0 & 7.0 & 53.5 & 34.0 & 7.0 & 53.5 & 34.6 \\
\hline
\end{tabular}

$$
0.011 .0 \quad 0.0 \quad 0.055 .0
$$

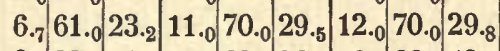

\begin{tabular}{l|l|l|l|l|l|l|l|l|l|l|}
0.52 .7 & 11.4 & 7.0 & 62.0 & 36.5 & 9.0 & 66.0 & 43.7 \\
\hline
\end{tabular}

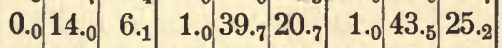

\begin{tabular}{l|l|l|l|l|l|l|l|l|}
0.0 & 37.7 & 14.7 & 4.0 & 67.0 & 31.1 & 4.0 & 69.0 & 36.4 \\
\hline
\end{tabular}

\begin{tabular}{lllllllllllll}
0.0 & 7.3 & 3.7 & 3.0 & 45.0 & 17.1 & 4.0 & 57.0 & 33.1 & 14.0 & 57.0 & 37.6 \\
\hline
\end{tabular}

\begin{tabular}{l|llllllllll}
0.0 & 16.0 & 4.7 & 3.0 & 60.0 & 18.1 & 7.0 & 66.0 & 21.5 \\
\hline
\end{tabular}

$\begin{array}{llllllllllllllll}0.0 & 5.5 & 1.5 & 0.0 & 24.0 & 8.9 & 0.0 & 53.0 & 14.4 & 1.0 & 58.0 & 20.5 & 8.5 & 58.0 & 25.0\end{array}$

\begin{tabular}{ll|l|l|l|l|l|l|l|l|l|l|l|l}
0.0 & 18.0 & 6.2 & 4.0 & 65.0 & 26.4 & 4.5 & 70.0 & 30.8 \\
\hline
\end{tabular}

6.0 $16.0 \quad 25$

$\begin{array}{lllllllllll}0.0 & 3.0 & 0.8 & 1.0 & 18.0 & 7.6 & 2.0 & 18.0 & 9.6\end{array}$ $\begin{array}{lllllllllll}1.0 & 19.0 & 20.0 & 38.0 & 28.0 & 44.0 & 29.7 & 44.0\end{array}$

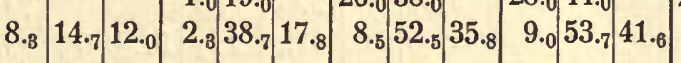

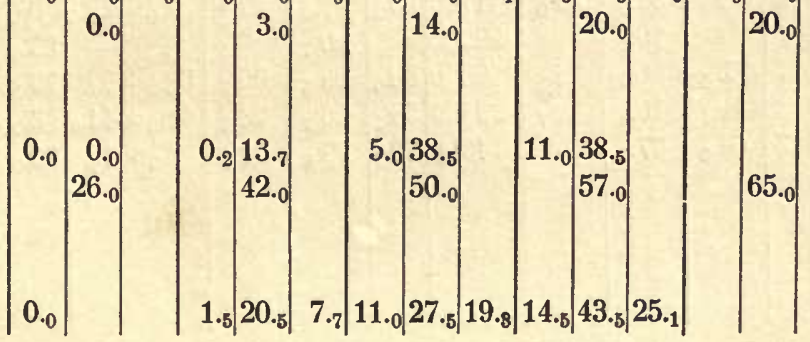

65. 


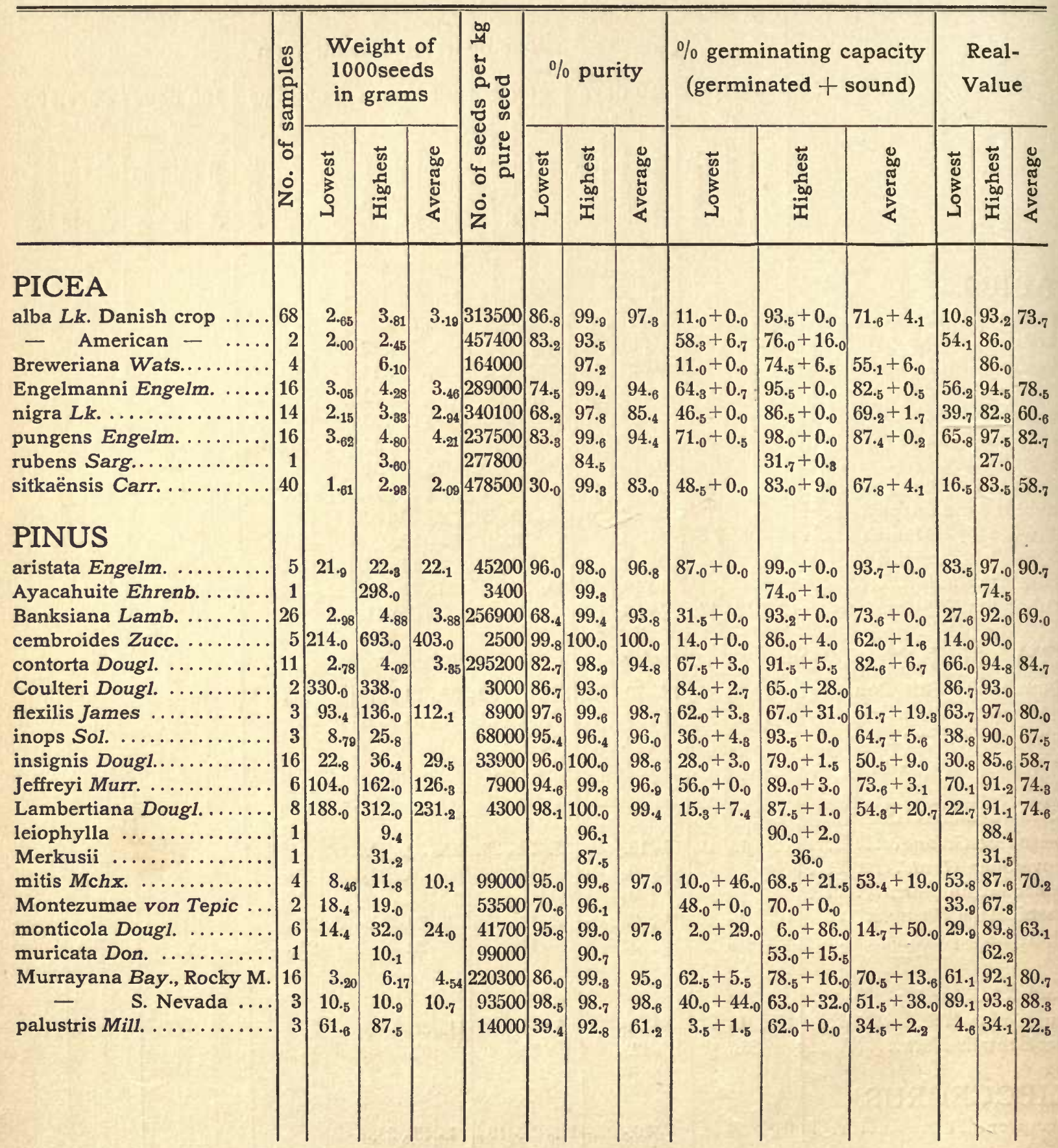


The course of germination

\begin{tabular}{|c|c|c|c|c|c|c|c|c|c|c|c|c|c|c|c|c|c|c|c|c|}
\hline \multicolumn{3}{|c|}{$\begin{array}{l}5 \text { days } \\
\% \%\end{array}$} & \multicolumn{3}{|c|}{$\begin{array}{l}10 \text { days } \\
\%\end{array}$} & \multicolumn{3}{|c|}{$\begin{array}{c}20 \text { days } \\
\%\end{array}$} & \multicolumn{3}{|c|}{$\begin{array}{c}30 \text { days } \\
\%\end{array}$} & \multicolumn{3}{|c|}{$\begin{array}{c}60 \text { days } \\
\%\end{array}$} & \multicolumn{3}{|c|}{$\begin{array}{c}100 \text { days } \\
\%\end{array}$} & \multicolumn{3}{|c|}{$\begin{array}{c}\text { over } 100 \\
\text { days } \%\end{array}$} \\
\hline है & 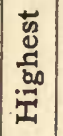 & 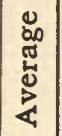 & $\begin{array}{l}\Delta \\
0 \\
0 \\
\vdots \\
0 \\
\text { a }\end{array}$ & 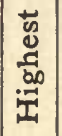 & 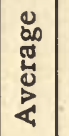 & $\begin{array}{l}\tilde{y} \\
0 \\
\vdots \\
0\end{array}$ & $\begin{array}{l}\text { 淢 } \\
\frac{4}{60}\end{array}$ & $\begin{array}{l}0 \\
0 \\
\pi \\
5 \\
5 \\
2 \\
\end{array}$ & $\begin{array}{l}\vec{y} \\
0 \\
3\end{array}$ & 惑 & 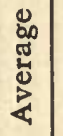 & 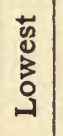 & 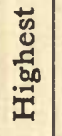 & 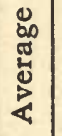 & $\begin{array}{l}5 \\
0 \\
0 \\
0 \\
\vdots\end{array}$ & 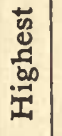 & 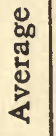 & $\begin{array}{l}n \\
0 \\
0 \\
0 \\
0 \\
\vdots\end{array}$ & 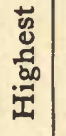 & 敢 \\
\hline
\end{tabular}

\section{PICEA}

\begin{tabular}{ll|l|l} 
alba $L k$. Danish crop ..... & 0.0 & 47.0
\end{tabular}

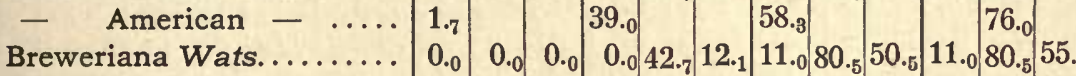

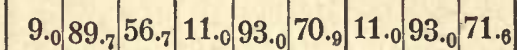

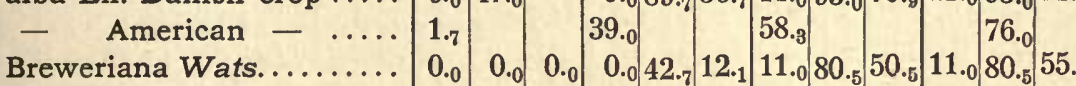

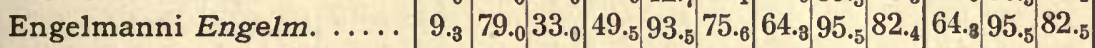

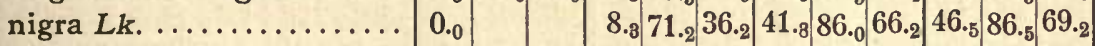

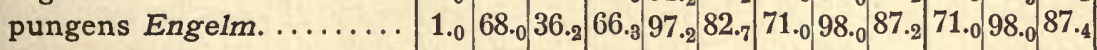

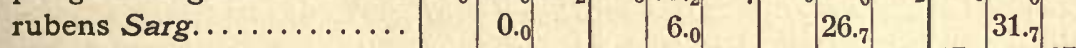

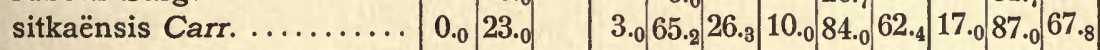

\section{PINUS}

aristata Engelm............

Ayacahuite Ehrenb........

Banksiana Lamb. ......... cembroides Zucc. ......... contorta Dougl. ........... Coulteri Dougl. ........... flexilis James ............ inops Sol............... insignis Dougt

Jeffreyi Murr. .............

Lambertiana Doug1.......

leiophylla .............

Merkusii ............... mitis $M c h x . \ldots \ldots \ldots \ldots$ Montezumae von Tepic.... monticola Dougl.......... muricata Don............ Murrayana Bay. Rocky M.. S. Nevada..... palustris Mill............

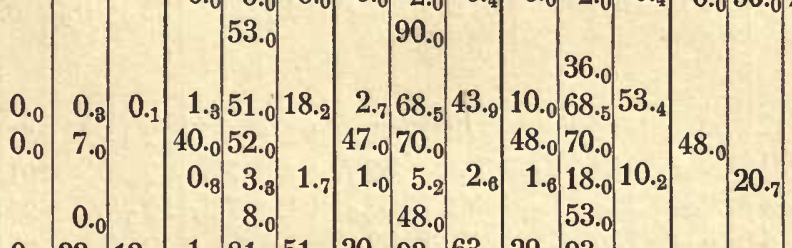

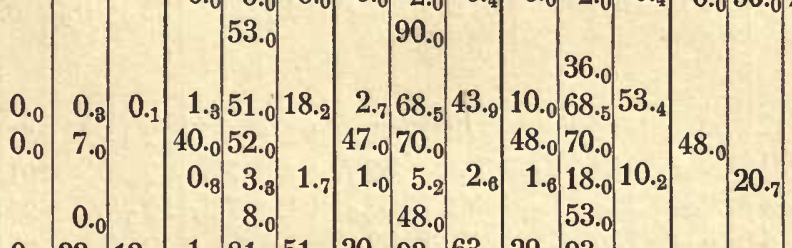

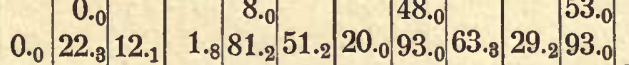

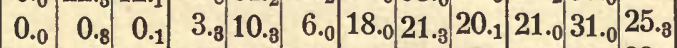

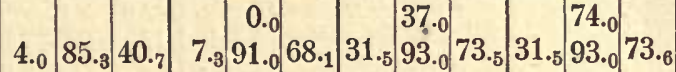
$\begin{array}{lllll}0.0 & 84.0 & 4.087 .0 \quad 88.0 & 14.0 & 88.0\end{array}$

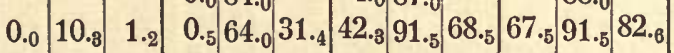

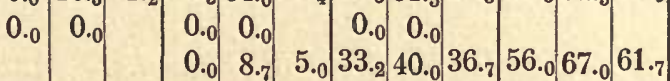

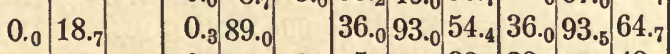

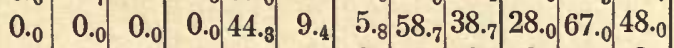

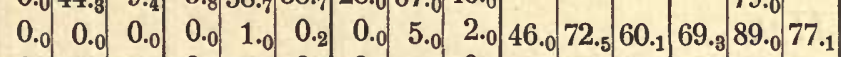

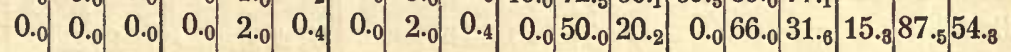

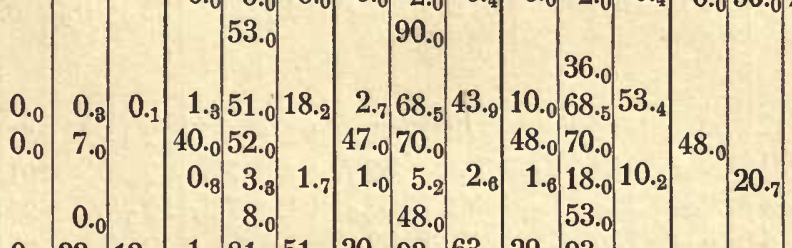
\begin{tabular}{rrr|r|r|r|r|r|r|r|r|r|r|}
0.0 & 0.8 & 0.1 & 3.8 & 10.8 & 6.0 & 18.0 & 21.3 & 20.1 & 21.0 & 31.0 & 25.3 \\
0.0 & 14.0 & 4.7 & 0.5 & 54.0 & 27.5 & 2.0 & 59.0 & 33.0
\end{tabular} 51.0 27.084 .0

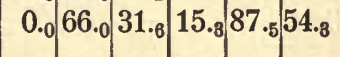




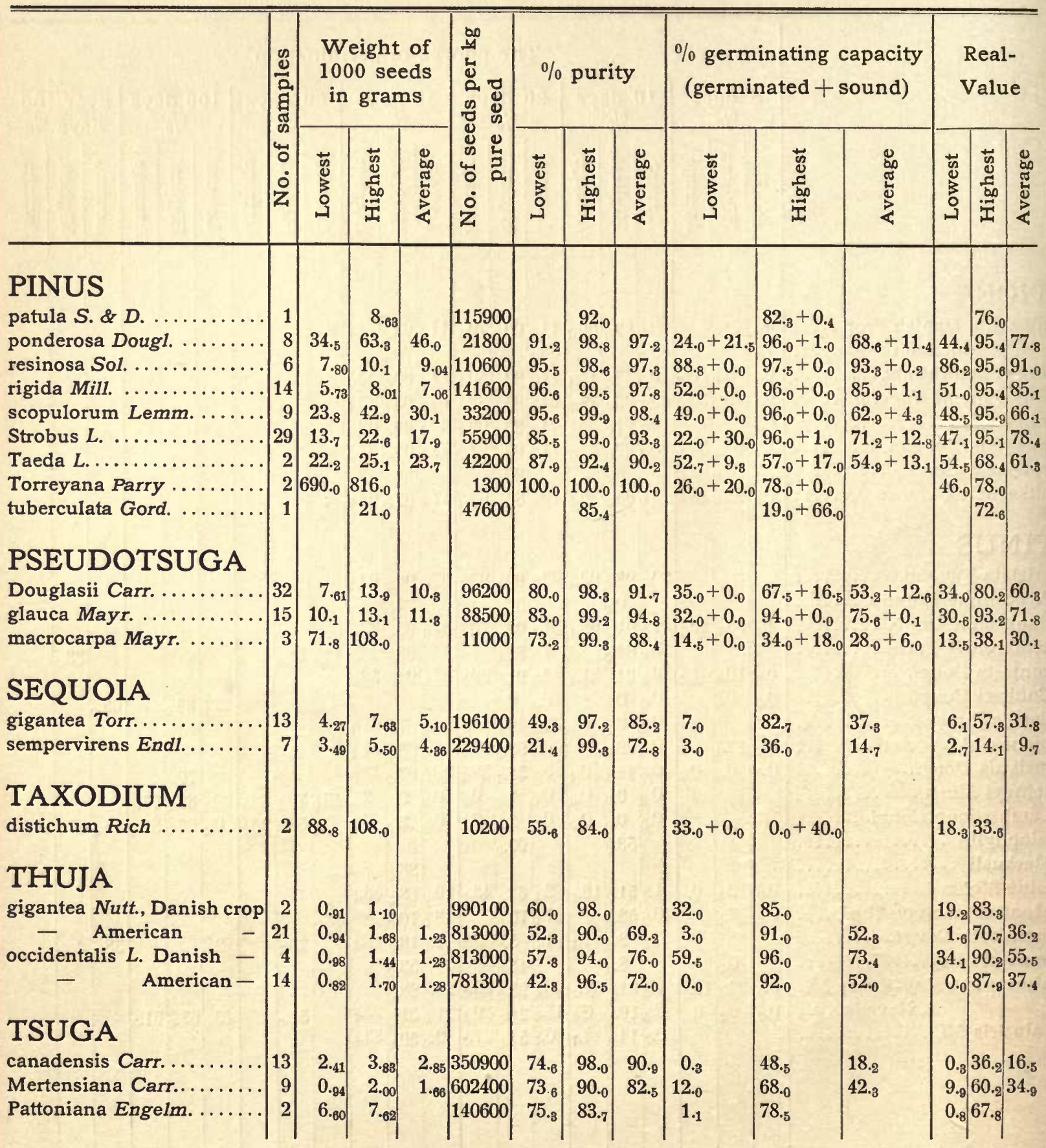




\section{5}

The course of germination

\begin{tabular}{|c|c|c|c|c|c|c|c|c|c|c|c|c|c|c|c|c|c|c|c|c|}
\hline \multicolumn{3}{|c|}{$\begin{array}{c}5 \text { days } \\
\%\end{array}$} & \multicolumn{3}{|c|}{$\begin{array}{c}10 \text { days } \\
\%\end{array}$} & \multicolumn{3}{|c|}{$\begin{array}{l}20 \text { days } \\
\%\end{array}$} & \multicolumn{3}{|c|}{$\begin{array}{c}30 \text { days } \\
\%\end{array}$} & \multicolumn{3}{|c|}{$\begin{array}{c}60 \text { days } \\
\%\end{array}$} & \multicolumn{3}{|c|}{$\begin{array}{c}100 \text { days } \\
\%\end{array}$} & \multicolumn{3}{|c|}{$\begin{array}{c}\text { over } 100 \\
\text { days } \%\end{array}$} \\
\hline $\begin{array}{l}\mathbf{y} \\
0 \\
0 \\
0 \\
0 \\
\text { d }\end{array}$ & 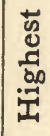 & 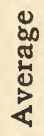 & 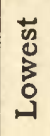 & 药 & $\begin{array}{l}0 \\
0 \\
\mathbb{\pi} \\
5 \\
5 \\
5\end{array}$ & 范 & $\begin{array}{l}\text { 荀 } \\
\frac{d}{60}\end{array}$ & $\begin{array}{l}0 \\
0 \\
0 \\
5 \\
0 \\
0 \\
\end{array}$ & 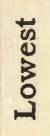 & 范 & 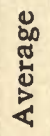 & 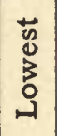 & 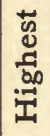 & 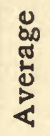 & 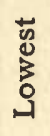 & $\begin{array}{l}\text { 苞 } \\
\text { 豆 } \\
\text { 蒫 }\end{array}$ & 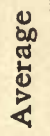 & $\begin{array}{l}\text { 荡 } \\
\vdots \\
0\end{array}$ & 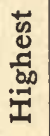 & 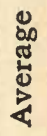 \\
\hline
\end{tabular}

\section{PINUS}

patula $S . \& D . \ldots \ldots \ldots \ldots$

ponderosa Dougl. .........

resinosa Sol.............

rigida Mill..............

scopulorum Lemm. ......

Strobus $L . \ldots \ldots \ldots \ldots$....

Taeda $L \ldots \ldots \ldots \ldots \ldots$........

Torreyana Parry ...........

tuberculata Gord.

PSEUDOTSUGA

Douglasii Carr............

glauca Mayr. ............
macrocarpa Mayr. . . .

$\begin{array}{llllllllllllllll}0.0 & 38.0 & 0.8 & 63.0 & 15.4 & 7.0 & 70.0 & 42.5 & 13.2 & 76.0 & 49.5 & 35.0 & 76.0 & 53.2\end{array}$

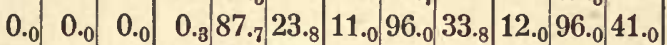

\begin{tabular}{llllllll}
0.0 & 48.3 & 92.7 & 71.6 & 88.8 & 97.5 & 93.8 \\
\hline
\end{tabular}

\begin{tabular}{llll|l|l|l|l|l|l|l|l|l}
0.0 & 71.7 & 36.5 & 5.3 & 92.7 & 67.2 & 48.0 & 96.0 & 85.5 \\
\hline
\end{tabular}

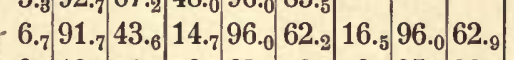

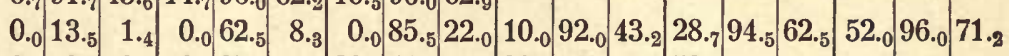

\begin{tabular}{l|lllll}
0.0 & 0.0 & 0.0 & 6.0 & 27.5 \\
\hline
\end{tabular}

\begin{tabular}{ll|l|l|l|}
0.0 & 4.0 & & \\
0.0 & & 2.5
\end{tabular}

20.341 .5

\begin{tabular}{l|l|l|l|l|}
38.0 & 57.0 & 52.7
\end{tabular}

$\left.\right|_{17.0}$

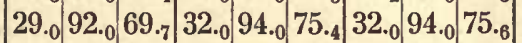

$\begin{array}{llllllllllllllllllll}0.0 & 0.0 & 0.0 & 0.0 & 1.5 & 0.7 & 1.0 & 3.3 & 2.1 & 2.5 & 24.7 & 14.1 & 14.5 & 36.0 & 28.0\end{array}$

SEQUOIA

gigantea Torr..............

sempervirens Endl........

$\begin{array}{lllllllllllllll}0.0 & 3.8 & 0.3 & 1.0 & 16.3 & 8.0 & 5.0 & 76.0 & 30.1 & 7.0 & 82.7 & 37.3\end{array}$

\begin{tabular}{llllllllllllll}
0.0 & 0.0 & 0.0 & 1.2 & 24.7 & 8.7 & 3.0 & 34.0 & 13.5 & 3.0 & 36.0 & 14.7 \\
\hline
\end{tabular}

\section{TAXODIUM}

distichum Rich..........

\section{THUJA}

gigantea Nutt., Danish crop

- American

occidentalis L. Danish -

$$
\text { - American - }
$$

\section{TSUGA}

canadensis Carr...........

Mertensiana Carr.........

Pattoniana Engelm.

$\begin{array}{llllllllllllllllllllll}0.0 & 0.0 & 0.0 & 0.0 & 1.3 & 0.3 & 0.0 & 2.5 & 1.1 & 0.0 & 5.0 & 1.5 & 0.0 & 42.5 & 12.5 & 2.3 & 48.5 & 18.2\end{array}$

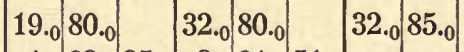

1.083 .035 .03 .091 .051 .2

\begin{tabular}{ll|l|l|l|l|l|l|l|}
46.7 & 77.2 & 57.5 & 59.5 & 96.0 & 73.1 \\
\hline
\end{tabular}

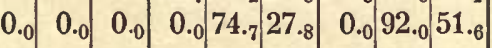

$\begin{array}{rrrrrrrrrrrr}0.0 & 0.0 & 0.0 & 0.0 & 1.3 & 0.3 & 0.0 & 2.5 & 1.1 & 0.0 & 5.0 & 1.5 \\ 0.0 & 0.3 & 0.0 & 0.0 & 20.3 & 3.8 & 0.0 & 46.0 & 19.7 & 9.3 & 68.0 & 37.0\end{array}$ 26.0 36.0

78. 0

19.0

\begin{tabular}{r|r|r|}
0.0 & 19.0 \\
0.0 & 1 & 80.0
\end{tabular}

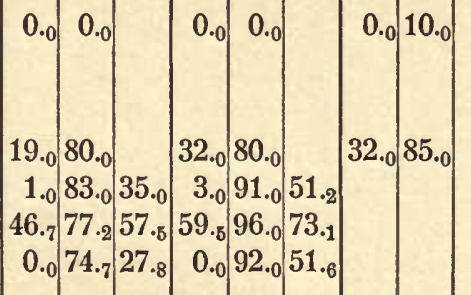

0.020 .0

0.033 .0

$$
0.0|53.3| 0.0|75.0| \quad|1.1| 78.5 \mid
$$





\section{TABLE III}

\section{JAPANESE CONIFERS}

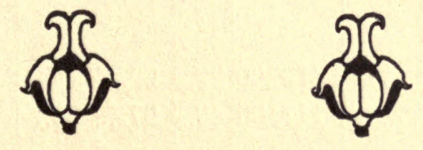

AVERAGE FIGURES FOR 25 YEARS 


\section{8}

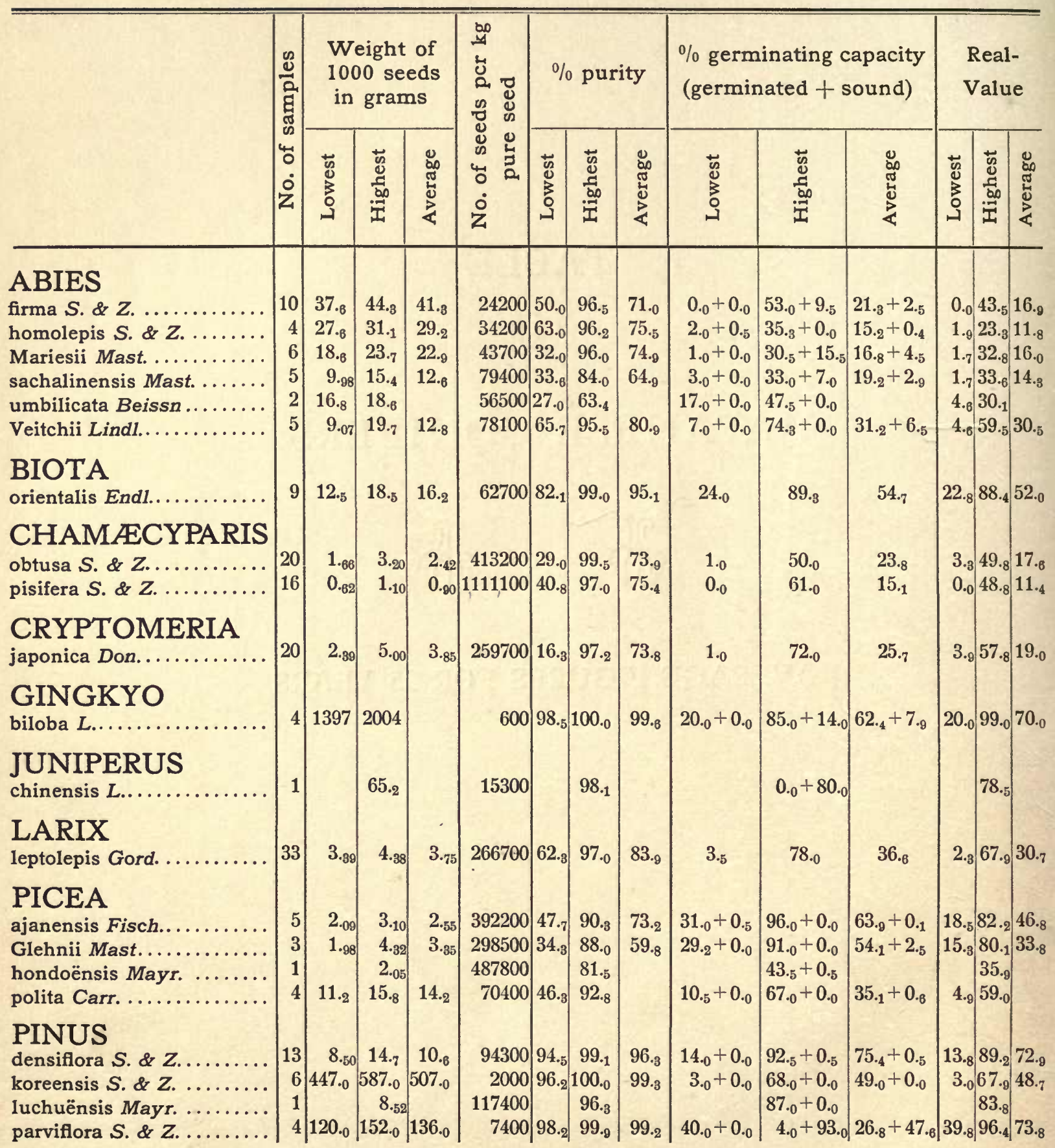


The course of germination

\begin{tabular}{|c|c|c|c|c|c|c|c|c|c|c|c|c|c|c|c|c|c|c|c|c|}
\hline \multicolumn{3}{|c|}{5 days } & \multicolumn{3}{|c|}{10 days } & \multicolumn{3}{|c|}{20 days } & \multicolumn{3}{|c|}{$\begin{array}{c}30 \text { days } \\
\%\end{array}$} & \multicolumn{3}{|c|}{$\begin{array}{c}60 \text { days } \\
\%\end{array}$} & \multicolumn{3}{|c|}{$\begin{array}{c}100 \text { days } \\
\%\end{array}$} & \multicolumn{3}{|c|}{$\begin{array}{c}\text { over } 100 \\
\text { days } \%\end{array}$} \\
\hline 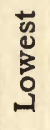 & 苞 & $\begin{array}{l}0 \\
0 \\
\pi \\
0 \\
0 \\
0\end{array}$ & 范 & 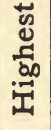 & 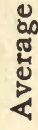 & $\overrightarrow{\mathrm{g}}$ & $\begin{array}{l}\text { 范 } \\
\frac{0}{00}\end{array}$ & $\begin{array}{l}0 \\
0 \\
0 \\
0 \\
0\end{array}$ & $\begin{array}{l}\bar{y} \\
\vdots\end{array}$ & 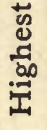 & 品 & 范 & 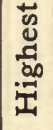 & 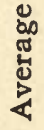 & 范 & 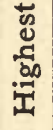 & $\begin{array}{l}\text { 品 } \\
\text { ॠ్ }\end{array}$ & $\begin{array}{l}\text { 范 } \\
\vdots \\
3\end{array}$ & 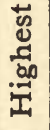 & $\underset{\sigma}{0}$ \\
\hline
\end{tabular}

\section{ABIES}

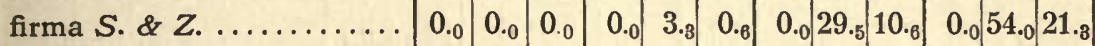

homolepis $S . \& Z$. ...... $0_{.0} \quad$\begin{tabular}{lllll|lllll}
0.0 & 1.0 & 0.5 & 1.0 & 13.5 & 7.3 & 2.0 & 35.3 & 15.2
\end{tabular}

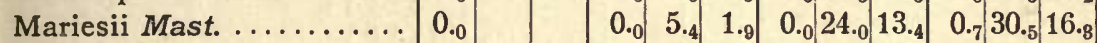

sachalinensis Mast. ...... $0_{.3} \quad \quad \quad \begin{array}{lllllllll}0.3 & 2.7 & 1.0 & 2.0 & 29.5 & 16.7 & 3.0 & 33.0 & 19.2\end{array}$

umbilicata Beissn ......... $0_{0_{0}}$

\begin{tabular}{rr|r|r|r|r|r|r|r|r|}
0.3 & 2.7 & 1.0 & 2.0 & 29.5 & 16.7 & 3.0 & 33.0 & 19.2 \\
0.0 & 0.0 & 0.0 & 15.0 & 32.0 & & 17.0 & 47.5 &
\end{tabular}

Veitchii Lindl. ........... 0.0

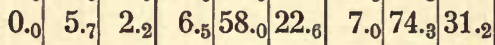

BIOTA

orientalis Endl.

CHAMECYPARIS

obtusa $S . \& Z \ldots \ldots \ldots \ldots \ldots 0_{0}$

pisifera $S . \& Z \ldots \ldots \ldots \ldots .0 .0$

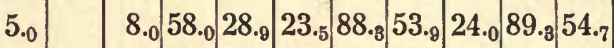

\section{CRYPTOMERIA}

japonica Don............

\section{GINGKYO}

biloba

\section{JUNIPERUS}

chinensis $L \ldots \ldots \ldots \ldots \ldots$.

\section{LARIX}

leptolepis Gord.

$\begin{array}{lll}0.0 & 3.0\end{array}$

\section{PICEA}

ajanensis Fisch......... $0_{0.0}$

Glehnii Mast. ............ $0_{0}$

hondoënsis Mayr.........

polita Carr. .............. 0.0

PINUS

densiflora $S . \&$ Z........ $0_{\cdot 0}$

koreensis $S$. \& Z .........

luchuënsis Mayr..........

parviflora S. \& Z.........

$\begin{array}{lllllllllllllll}0.0 & 0.0 & 0.0 & 0.0 & 20.5 & 4.8 & 0.0 & 50.0 & 17.2 & 5.5 & 72.0 & 25.7\end{array}$

$\begin{array}{llllllllll}0.0 & 27.7 & 9.3 & 1.0 & 48.7 & 22.7 & 1.0 & 50.0 & 23.8\end{array}$

$\begin{array}{llllllllll}0.0 & 26.7 & 6.4 & 0.0 & 61.0 & 14.1 & 0.0 & 61.0 & 15.1\end{array}$

$\begin{array}{lllllllll}0.0 & 16.0 & 7.5 & 5.0 & 65.0 & 35_{.5} & 10.0 & 70.0 & 50.8\end{array}$

20.087 .562 .4

\begin{tabular}{llllllllll}
0.0 & 22.8 & 8.0 & 0.7 & 64.5 & 29.4 & 3.5 & 78.0 & 36.6 \\
\hline
\end{tabular}

17.0 87.0 51.1 31.0 94.7 61.8 31.0 96.063 .9

19.0 86.7 43.5 28.0 91.053 .929 .8 91.0 54.1

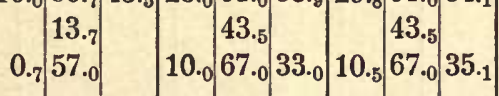

\begin{tabular}{llllllllllllllllll}
0.0 & 80.0 & 37.8 & 11.5 & 88.7 & 72.8 & 14.0 & 92.5 & 75.4 & 0.0 & 23.0 & 6.1 & 0.0 & 36.0 & 10.3 & $\overbrace{3.0}^{\text {c. } 400 \text { days }}$ \\
\hline
\end{tabular} $0.0 \quad 75.0 \quad 0.0 \quad 0.0 \quad \begin{array}{lll}0.0 & 6.3 & 1.7 \\ 87.0 & 0.0\end{array} \quad$ c. 270 days

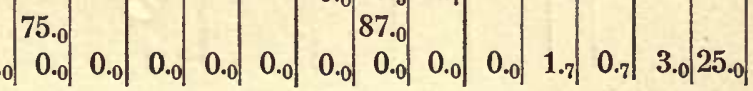

|40.0 
80

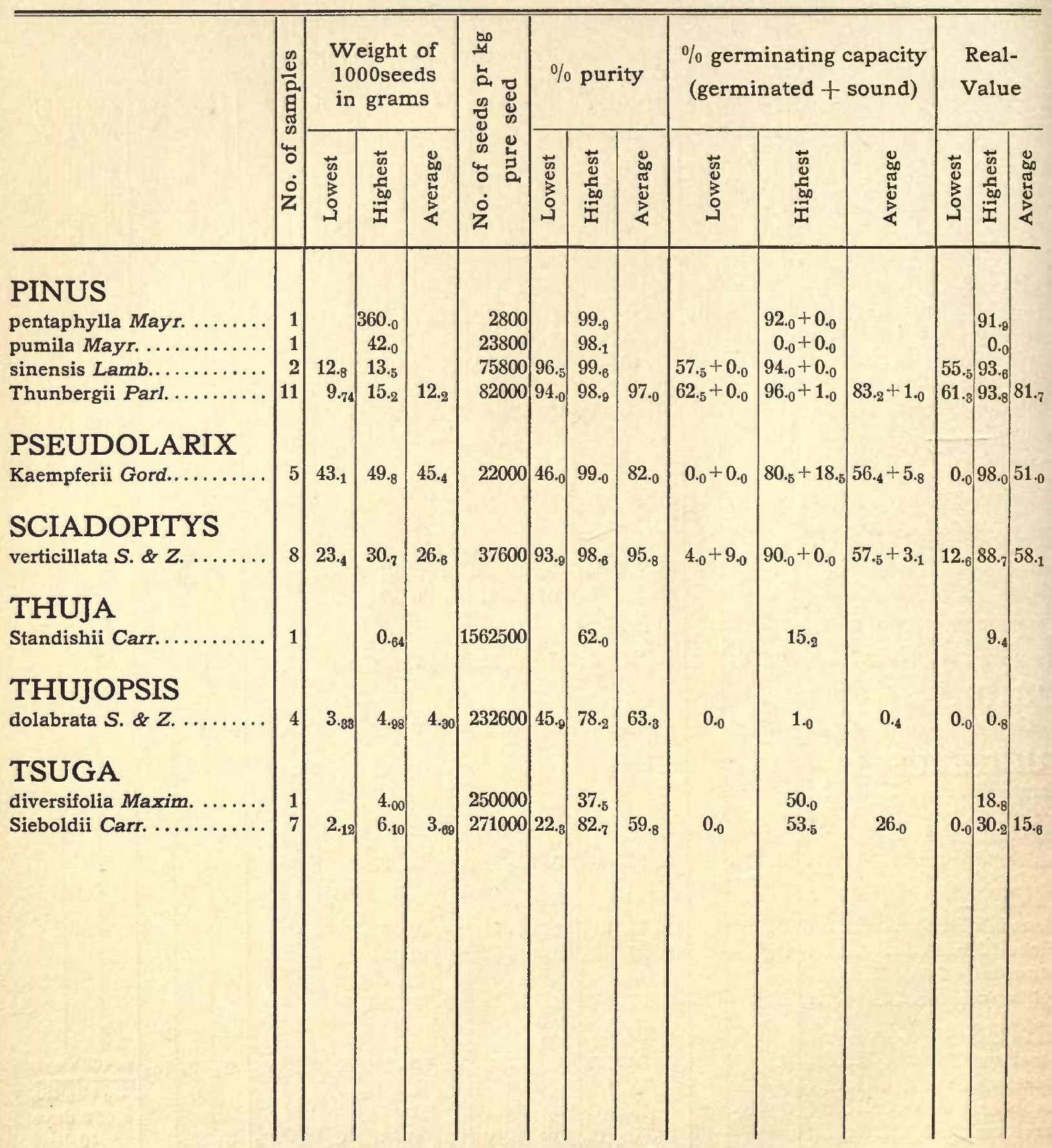


The course of germination

\begin{tabular}{|c|c|c|c|c|c|c|c|c|c|c|c|c|c|c|c|c|c|c|c|c|}
\hline \multicolumn{3}{|c|}{$\begin{array}{l}5 \text { days } \\
\%\end{array}$} & \multicolumn{3}{|c|}{10 days } & \multicolumn{3}{|c|}{20 days } & \multicolumn{3}{|c|}{$\begin{array}{c}30 \text { days } \\
\%\end{array}$} & \multicolumn{3}{|c|}{60 days } & \multicolumn{3}{|c|}{$\begin{array}{c}100 \text { days } \\
\%\end{array}$} & \multicolumn{3}{|c|}{$\begin{array}{c}\text { over } 100 \\
\text { days } \%\end{array}$} \\
\hline 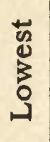 & 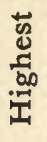 & $\begin{array}{l}0 \\
0 \\
\pi \\
0 \\
0\end{array}$ & 苅 & 苞 & 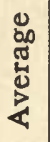 & $\begin{array}{l}\vec{y} \\
0 \\
3\end{array}$ & $\begin{array}{l}\vec{y} \\
\stackrel{d}{y}\end{array}$ & $\begin{array}{l}\text { 峁 } \\
\pi \\
\pi\end{array}$ & $\begin{array}{l}\text { 荡 } \\
3\end{array}$ & 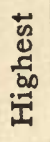 & $\begin{array}{l}\text { 总 } \\
\text { శ్ }\end{array}$ & $\begin{array}{l}\overrightarrow{\mathrm{v}} \\
\mathrm{d}\end{array}$ & 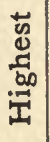 & 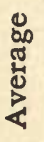 & $\begin{array}{l}\overrightarrow{\mathrm{y}} \\
\vdots \\
\vdots\end{array}$ & 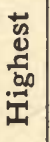 & 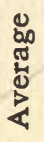 & $\begin{array}{l}\text { 范 } \\
\vdots \\
0 \\
0\end{array}$ & 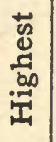 & ซึ \\
\hline
\end{tabular}

\section{PINUS}

pentaphylla Mayr. .......

pumila Mayr. ...........

sinensis Lamb..........

Thunbergii Parl. ........ 0.

\section{PSEUDOLARIX}

Kaempferii Gord..........

\section{SCIADOPITYS}

verticillata $S . \& Z$. .......

\section{THUJA}

Standishii Carr...........

\section{THUJOPSIS}

dolabrata $S . \& Z$. ........

\section{TSUGA}

diversifolia Maxim. ...... Sieboldii Carr.

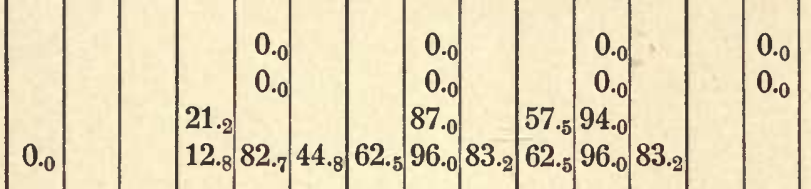

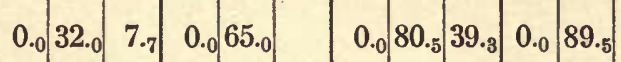

$\begin{array}{lllllllll}0.0 & 0.3 & 0.0 & 0.0 & 1.0 & 0.2 & 0.0\end{array}$

13.

15.

$\begin{array}{lllllllllll}0.0 & 0.0 & 0.0 & 0.0 & 0.0 & 0.0 & 0.0 & 1.0 & 0.4\end{array}$

$\begin{array}{lllllll}0.0 & 0.0 & 30.0 & 48.0 & 50.0\end{array}$ \begin{tabular}{llllllllll}
0.0 & 4.7 & 1.5 & 0.0 & 39.5 & 19.9 & 0.0 & 53.5 & 24.8 \\
\hline
\end{tabular} c. $\mathbf{4 0 0}$ days

920 


\section{TABLE IV}

\section{THE SEED \\ OF BROAD-LEAVED TREES

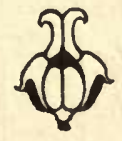

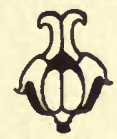

AVERAGE FIGURES FOR 25 YEARS 


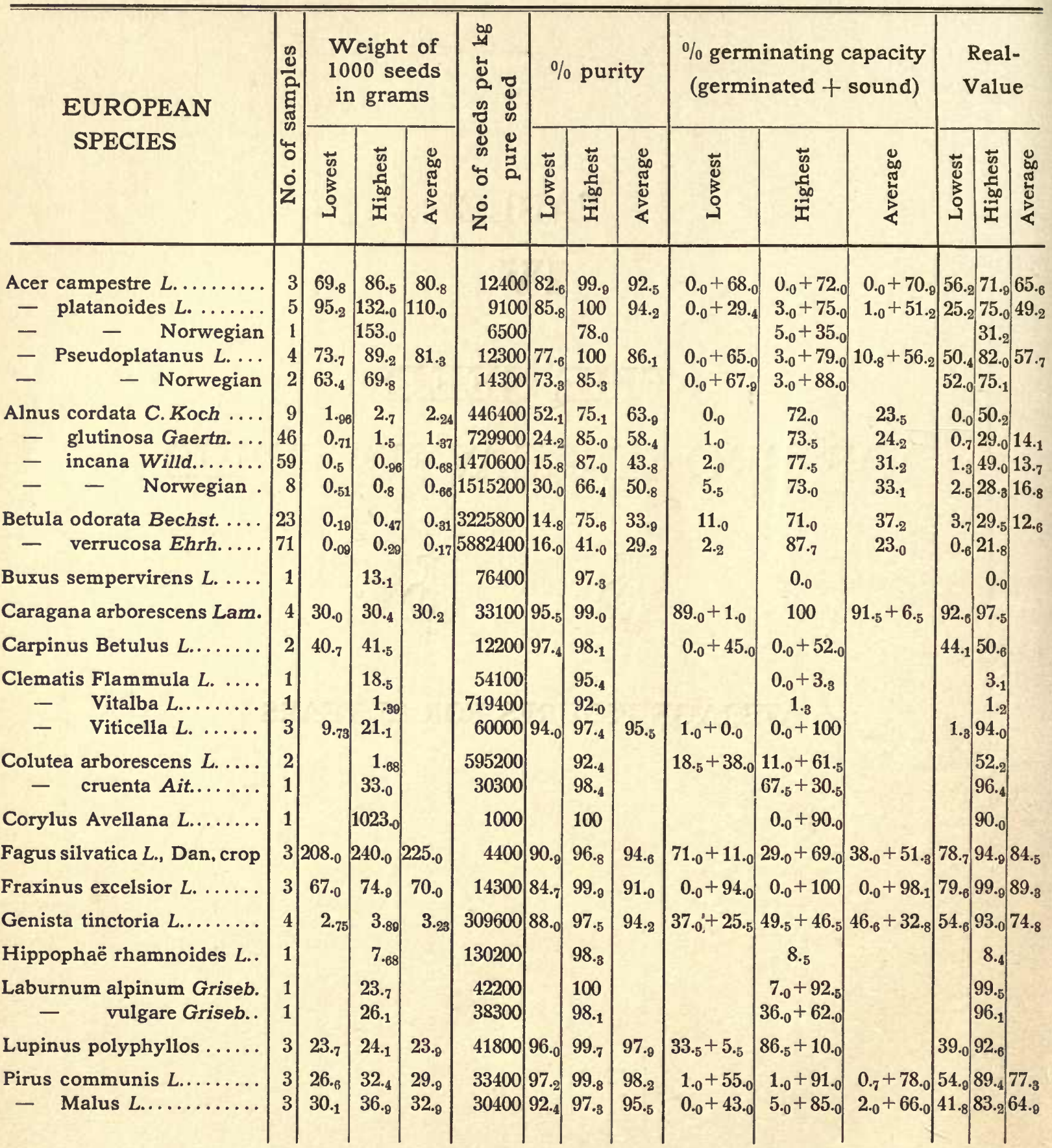


The course of germination

Acer campestre L........

- platanoides $L$. .....

- - Norwegian

- Pseudoplatanus $L$. . .

- - Norwegian

Alnus cordata C. Koch ....

- glutinosa Gaertn....

- incana Willd.......

- - Norwegian.

Betula odorata Bechst. ....

- verrucosa Ehrh.....

Buxus sempervirens $L$. . . .

Caragana arborescens Lam.

Carpinus Betulus $L . \ldots$. . .

Clematis Flammula $L . . .$.

- Vitalba L........

- Viticella L.......

Colutea arborescens $L$....

- cruenta Ait.......

Corylus Avellana L.......

Fagus silvatica $L$., Dan. crop

Fraxinus excelsior $L$. . . . .

Genista tinctoria $L \ldots \ldots \ldots$.

Hippophaë rhamnoides $L$..

Laburnum alpinum Griseb. - vulgare Griseb. .

Lupinus polyphyllos ...... 11.3

Pirus communis $L \ldots \ldots \ldots$.

- Malus L...........

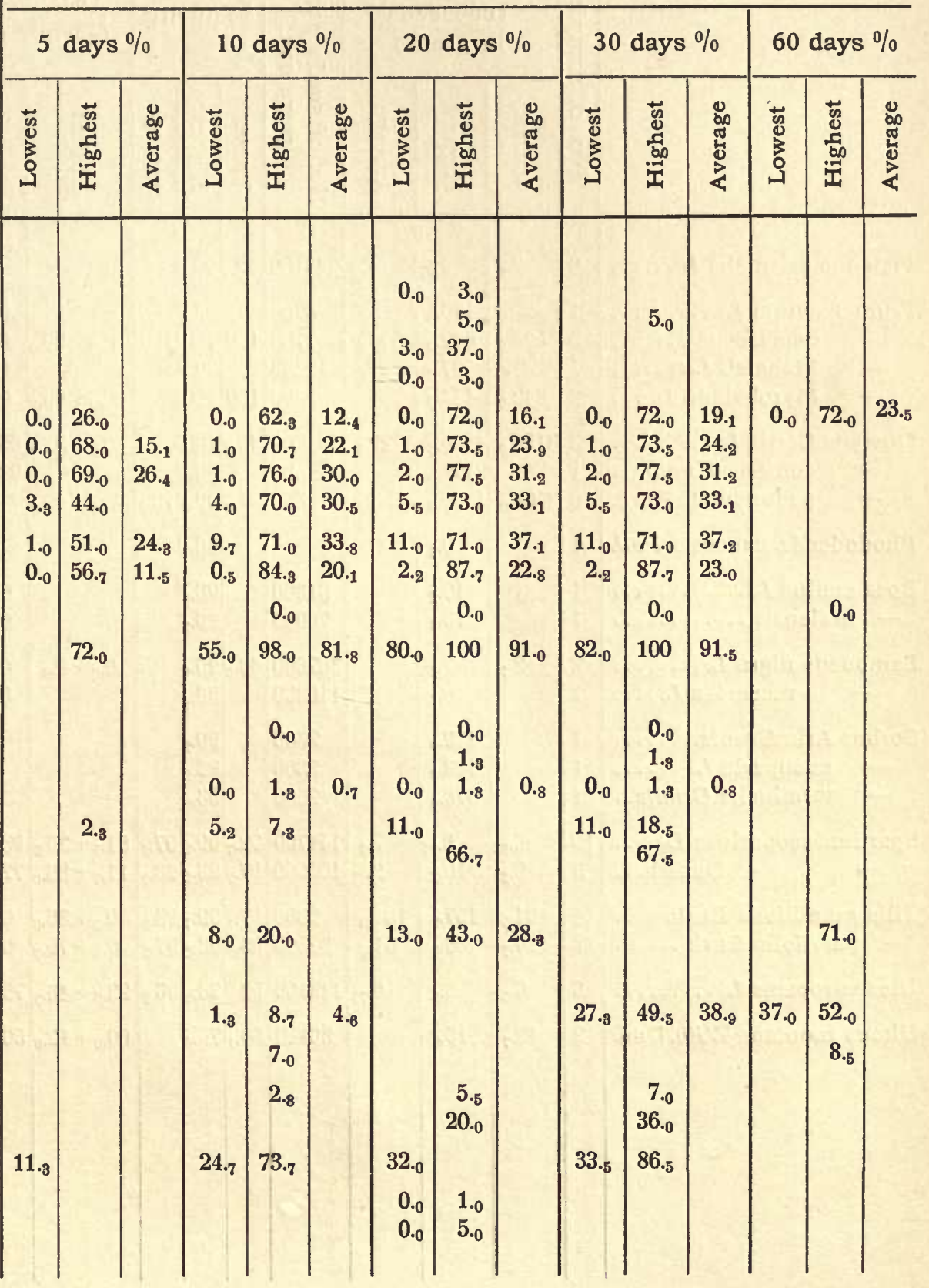




\section{6}

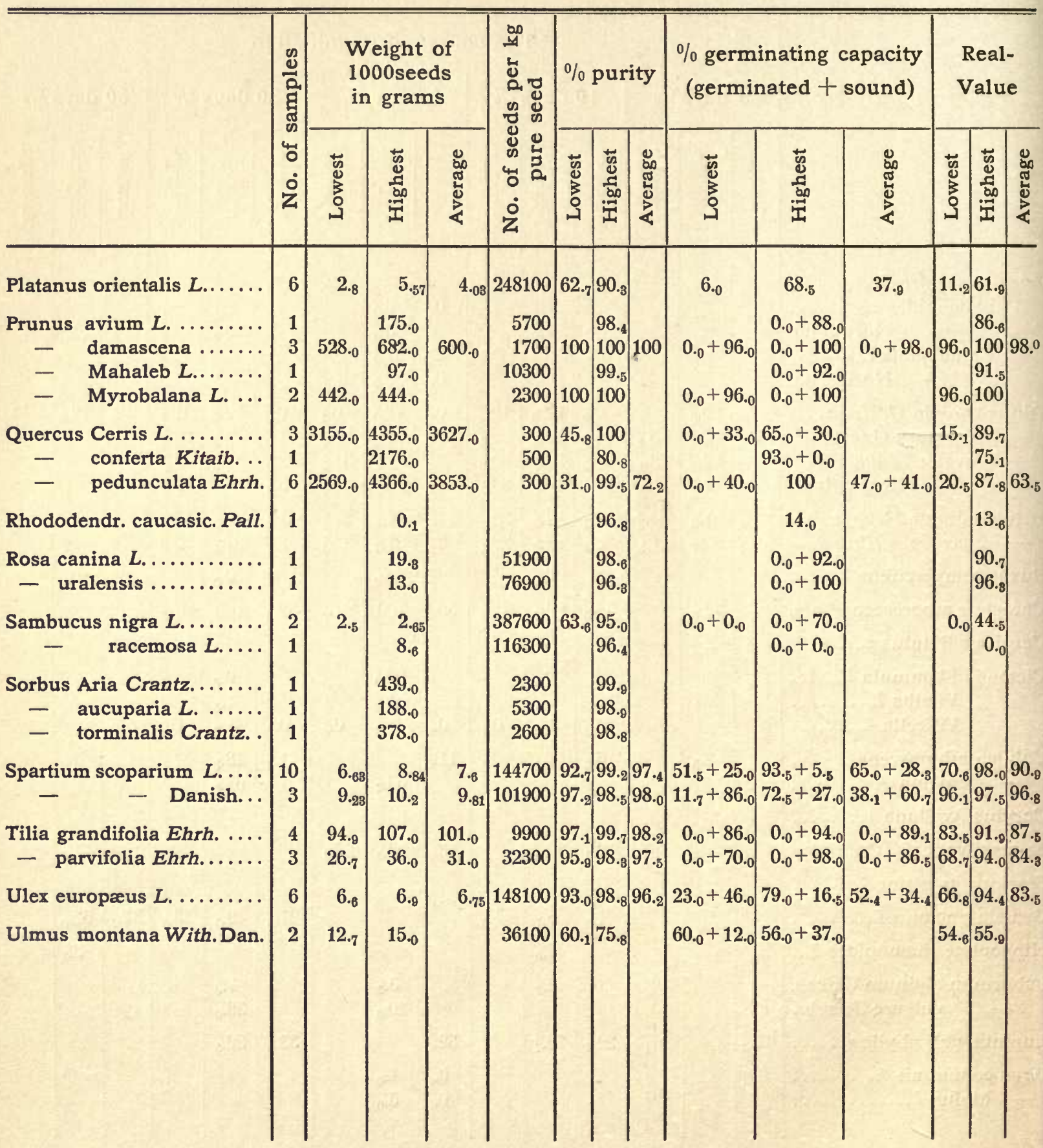


The course of germination

Platanus orientalis $L . \ldots$.

Prunus avium $L . \ldots \ldots \ldots$.

- damascena.......

- Mahaleb L. ......

- Myrobalana L....

Quercus Cerris $L . \ldots \ldots \ldots$.

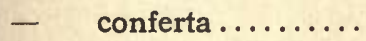

- pedunculata Ehrh.

Rhododendr. caucasic. Pall.

Rosa canina $L . \ldots \ldots \ldots \ldots$

- uralensis ...........

Sambucus nigra $L . . . .$. . - racemosa $L$. ..

Sorbus Aria Crantz........

- aucuparia $L . . . .$. .

- torminalis Crantz. .

Spartium scoparium L.... 2.3

$$
\text { - - Danish }
$$

Tilia grandifolia Ehrh. ....

- parvifolia Ehrh......

Ulex europæus $L$. ........

Ulmus montana With., Dan.

\begin{tabular}{|c|c|c|c|c|c|c|c|c|c|c|c|c|c|c|}
\hline \multicolumn{3}{|c|}{5 days $\%$} & \multicolumn{3}{|c|}{10 days $\%$} & \multicolumn{3}{|c|}{20 days $\%$} & \multicolumn{3}{|c|}{30 days $\%$} & \multicolumn{3}{|c|}{60 days $\%$} \\
\hline 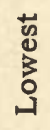 & 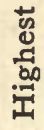 & 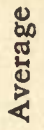 & 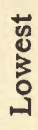 & 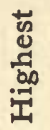 & $\begin{array}{l}0 \\
0 \\
0 \\
0 \\
0 \\
0\end{array}$ & 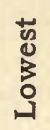 & 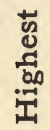 & 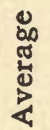 & $\begin{array}{l}\text { 芯 } \\
\vdots \\
0 \\
0 \\
0\end{array}$ & 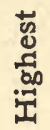 & 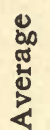 & 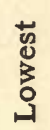 & 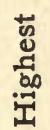 & 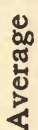 \\
\hline
\end{tabular}

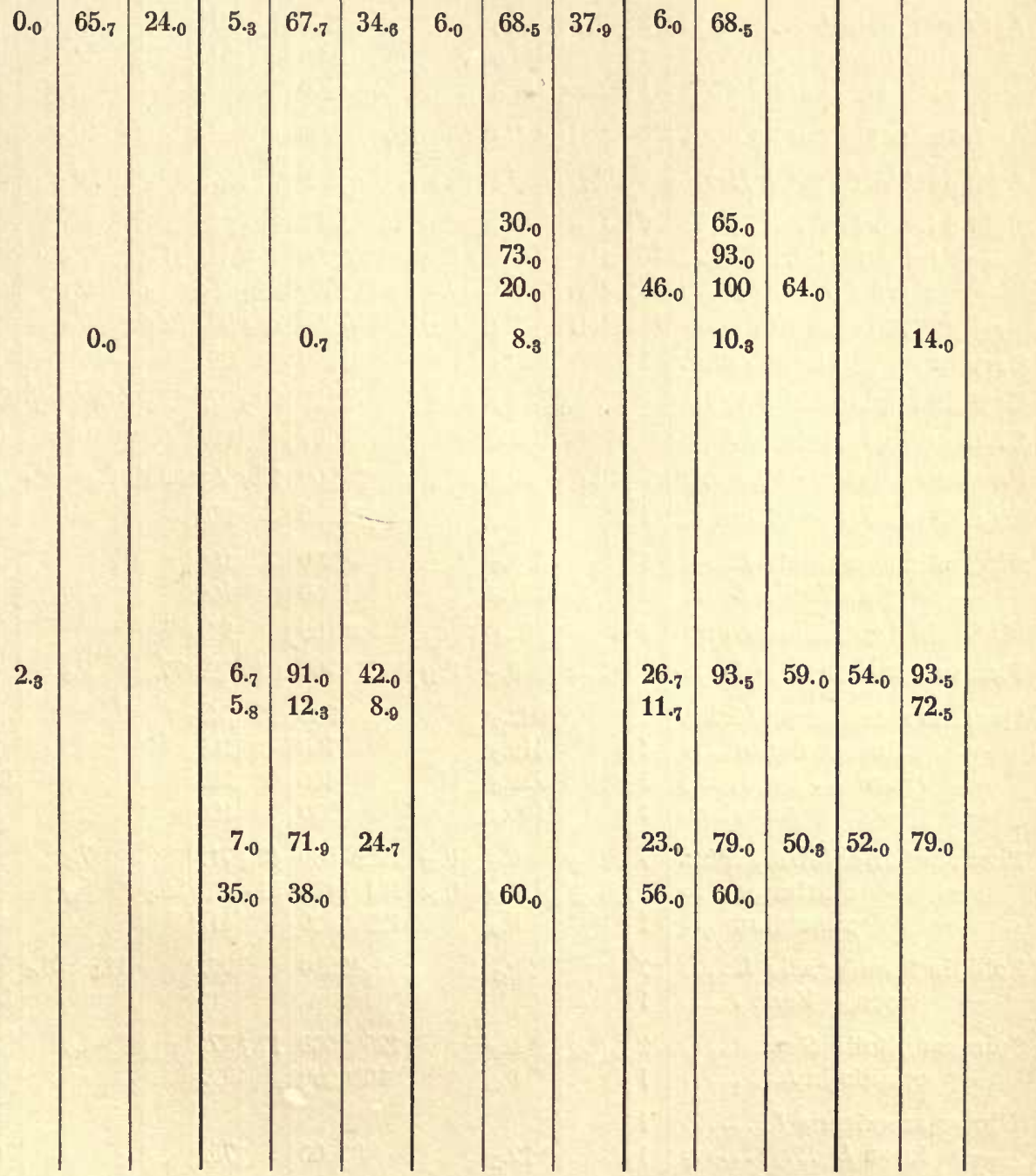




\section{8}

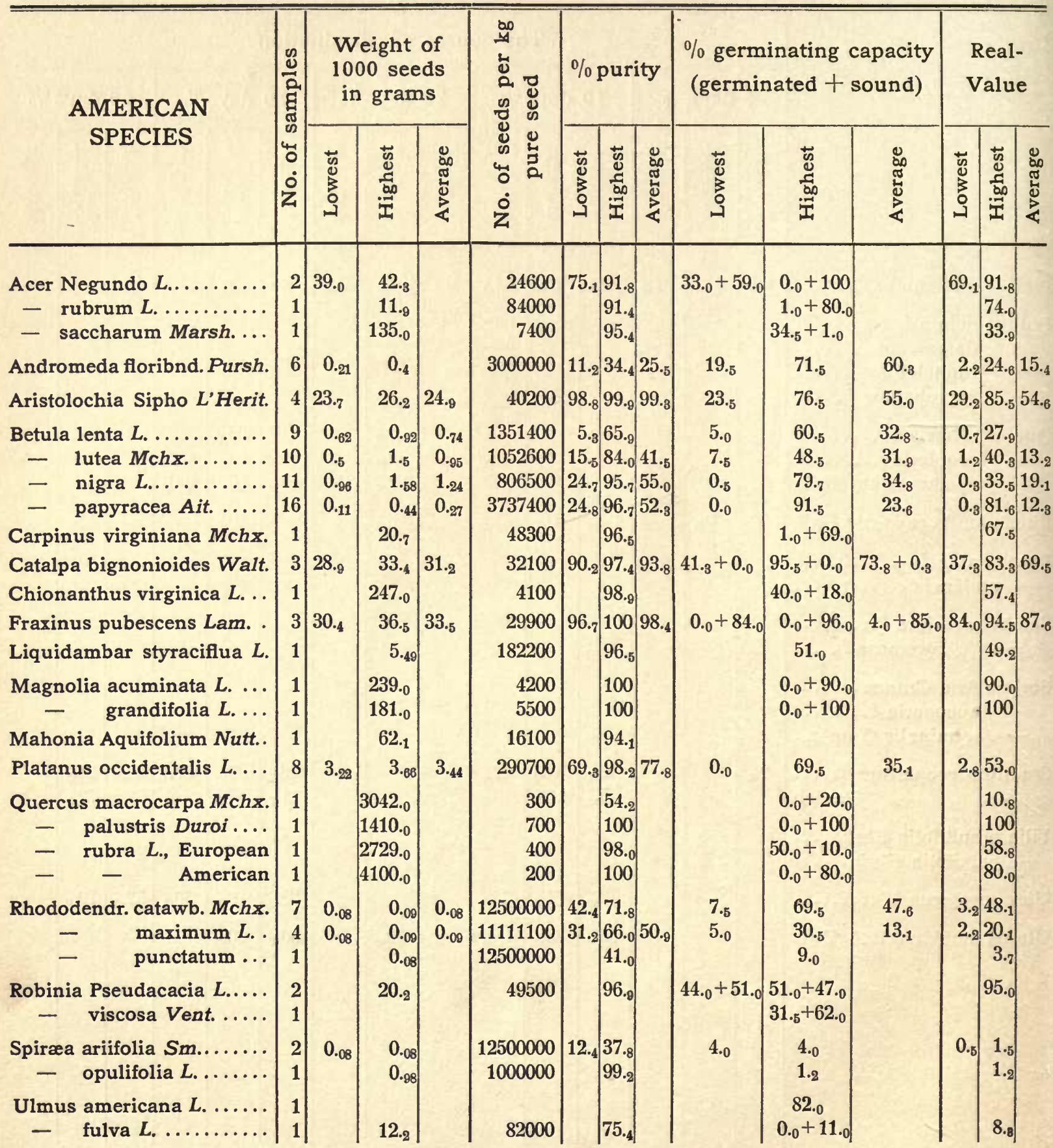




\section{9}

The course of germination

\begin{tabular}{|c|c|c|c|c|c|c|c|c|c|c|c|c|c|c|c|c|c|}
\hline \multicolumn{3}{|c|}{$\begin{array}{c}5 \text { days } \\
\%\end{array}$} & \multicolumn{3}{|c|}{$\begin{array}{l}10 \text { days } \\
\%\end{array}$} & \multicolumn{3}{|c|}{$\begin{array}{c}20 \text { days } \\
\%\end{array}$} & \multicolumn{3}{|c|}{$\begin{array}{c}30 \text { days } \\
\%\end{array}$} & \multicolumn{3}{|c|}{$\begin{array}{c}60 \text { days } \\
\%\end{array}$} & \multicolumn{3}{|c|}{$\begin{array}{c}565 \text { days } \\
\%\end{array}$} \\
\hline $\begin{array}{l}\text { 菋 } \\
\text { है }\end{array}$ & 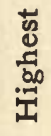 & 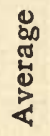 & 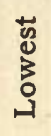 & 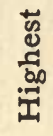 & 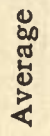 & $\begin{array}{l}\tilde{y} \\
0 \\
\vdots \\
0 \\
\end{array}$ & 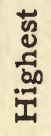 & 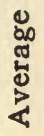 & 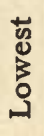 & 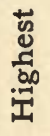 & 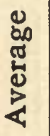 & $\begin{array}{l}\text { 苍 } \\
\vdots \\
\text { 苂 }\end{array}$ & 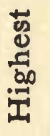 & 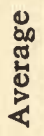 & $\begin{array}{l}\text { 范 } \\
\text { 岁 } \\
\text { ఏ }\end{array}$ & 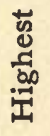 & 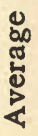 \\
\hline
\end{tabular}

Acer Negundo $L \ldots \ldots \ldots$....

- rubrum $L . \ldots . . . .$. .

- saccharum Marsh...

Andromeda floribnd. Pursh.

Aristolochia Sipho L'Herit.

Betula lenta $L$...........

- lutea Mchx.........

- nigra $L \ldots . . . \ldots . .$. .

- papyracea Ait.....

Carpinus virginiana $M c h x$.

Catalpa bignonioides Walt.

Chionanthus virginica $L$.. .

Fraxinus pubescens Lam. .

Liquidambar styraciflua $L$.

Magnolia acuminata $L . .$. .

- grandifolia $L$....

Mahonia Aquifolium Nutt. .

Platanus occidentalis $L$. ...

Quercus macrocarpa $M c h x$.

- palustris Duroi. ..

- rubra. European.

- - American .

Rhododendr. catawb. Mchx.

- maximum $L$. .

- punctatum...

Robinia Pseudacacia $L . .$. .

- viscosa Vent.....

Spiræa ariifolia $\mathbf{S m} . . . . .$.

- opulifolia $L . \ldots .$. .

Ulmus americana $L . \ldots$.

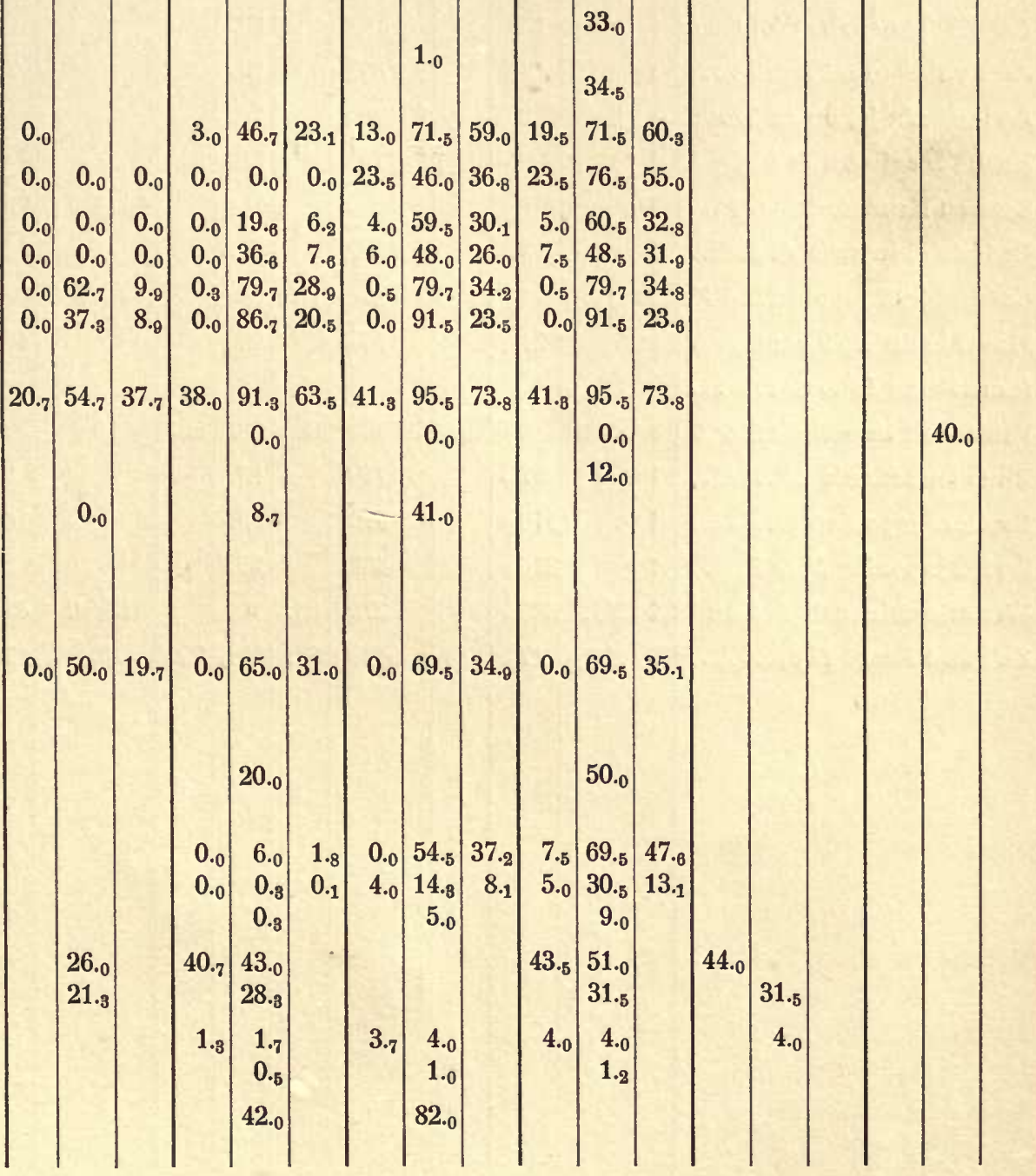




\section{0}

\begin{tabular}{|c|c|c|c|c|c|c|c|c|c|c|c|c|c|c|}
\hline \multirow{2}{*}{ JAPANESE SPECIES } & \multirow{2}{*}{$\mid \begin{array}{c}0 \\
0 \\
0 \\
2 \\
\text { g్ } \\
8 \\
0 \\
4 \\
0 \\
0 \\
0 \\
z\end{array}$} & \multicolumn{3}{|c|}{$\begin{array}{l}\text { Weight sf } \\
1000 \text { seeds } \\
\text { in grams }\end{array}$} & \multirow{2}{*}{ 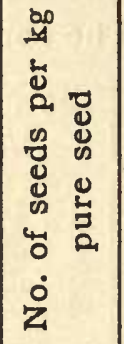 } & \multicolumn{3}{|c|}{$\%$ purity } & \multicolumn{3}{|c|}{$\begin{array}{l}\% \text { germinating capacity } \\
\text { (germinated + sound) }\end{array}$} & \multicolumn{3}{|c|}{$\begin{array}{l}\text { Real- } \\
\text { Value }\end{array}$} \\
\hline & & 范 & 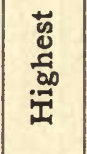 & $\begin{array}{l}0 \\
0 \\
5 \\
5 \\
0 \\
5 \\
4\end{array}$ & & 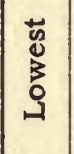 & 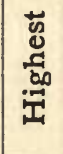 & 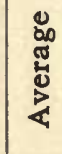 & $\begin{array}{l}\text { 㟧 } \\
0 \\
0 \\
0 \\
1\end{array}$ & 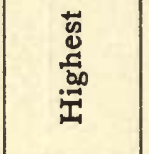 & $\begin{array}{l}0 \\
80 \\
0 \\
0 \\
0 \\
0\end{array}$ & $\begin{array}{l}\Delta \\
0 \\
0 \\
0 \\
0 \\
\omega\end{array}$ & 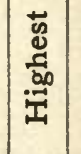 & 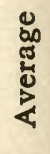 \\
\hline Acanthopanax ricinifol. Dcn. & 1 & & 13.2 & & 75800 & & 96.7 & & & $0.0+15.0$ & & & 14.5 & \\
\hline Acer palmatum Thunb.... & 1 & & $\mid 12.9$ & & 77500 & & 85.6 & & & $2.0+0.0$ & & & 1.7 & \\
\hline Andromeda japonica $T h n b$. & 1 & & 0.15 & & 6666700 & & 14.3 & & & 2.5 & & & 0.4 & \\
\hline Betula Maximowiczii Regl. & 4 & 0.2 & 0.81 & 0.27 & 3703700 & 0.6 & 36.8 & 25 & 0.0 & 1.5 & 0.5 & 0.0 & 0.4 & \\
\hline Catalpa Kæmpferi S. \& Z... & 3 & & & & & & & & $86.0+3.0$ & $96.0+3.0$ & $91.7+2.8$ & & & \\
\hline Cedrela chinensis A. Juss.. & 1 & & 12.8 & & 77500 & & 83.1 & & & $|14.5+17.0|$ & & & 26.2 & \\
\hline Cercidiphyll.japonic.S.\&Z. & 7 & 0.62 & 0.8 & 0.88 & 1470600 & 10.0 & 60.0 & & 0.0 & 55.0 & 22.8 & 0.0 & 0 & \\
\hline Hovenia dulcis Thunb.... & 1 & & 24.3 & & 44800 & & 98.5 & & & $40.0+6.0$ & & & 45.8 & \\
\hline Morus alba $L . \ldots \ldots \ldots \ldots$ & 1 & & & & & & & & & 67.0 & & & & \\
\hline Paulownia imperialis $S . \& Z$. & 8 & 0.15 & 0.27 & 0.20 & 5000000 & 60.8 & 83.0 & 69. & 13.0 & 85.5 & 61.0 & 10.8 & 57.2 & \\
\hline Rhus succedania $L . \ldots \ldots$. & 1 & & 57.8 & & 17400 & & 98.4 & & & $0.5+60.0$ & & & 59.5 & \\
\hline Sophora japonica $L . . . .$. . & 1 & & 110.0 & & 9100 & & 99.1 & & & $16.5+17.5$ & & & 33.7 & \\
\hline Styrax japonica S. \& Z.... & 1 & & 216.0 & & 4600 & & 96.7 & & & $0.0+11.0$ & & & 10.8 & \\
\hline Wistaria chinensis de Cand. & 2 & 367.0 & 380.0 & & 2700 & 98.0 & 100 & & $4.0+0.0$ & $42.7+0.0$ & & 3.9 & 42.7 & \\
\hline Zelkowa Keaki Dipp....... & 3 & 16.6 & 17.5 & 17.0 & 58800 & 94.8 & 97.0 & 95 & 0.0 & $43.0+19.0$ & & 0.0 & 58.8 & \\
\hline
\end{tabular}


The course of germination

\begin{tabular}{|c|c|c|c|c|c|c|c|c|c|c|c|c|c|c|c|c|c|}
\hline \multicolumn{3}{|c|}{5 days } & \multicolumn{3}{|c|}{$\begin{array}{l}10 \text { days } \\
\% \%\end{array}$} & \multicolumn{3}{|c|}{$\begin{array}{l}20 \text { days } \\
\%\end{array}$} & \multicolumn{3}{|c|}{$\begin{array}{c}30 \text { days } \\
\%\end{array}$} & \multicolumn{3}{|c|}{$\begin{array}{c}60 \text { days } \\
\%\end{array}$} & \multicolumn{3}{|c|}{$\begin{array}{c}100 \text { days } \\
\%\end{array}$} \\
\hline $\begin{array}{l}\overrightarrow{\mathrm{s}} \\
\vdots \\
0 \\
0 \\
\end{array}$ & 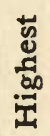 & 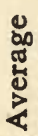 & $\begin{array}{l}\text { 㟧 } \\
0 \\
0 \\
0 \\
0\end{array}$ & 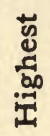 & 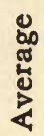 & 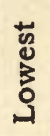 & $\begin{array}{l}\text { 苞 } \\
\frac{d}{60}\end{array}$ & 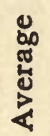 & $\begin{array}{l}\text { 剀 } \\
\text { 岁 } \\
0\end{array}$ & 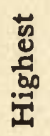 & 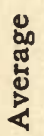 & 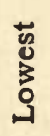 & 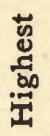 & 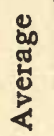 & 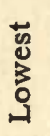 & 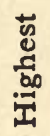 & 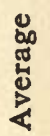 \\
\hline
\end{tabular}

Acanthopan. ricinifol. Decn. Acer palmatum Thunb.... Andromeda japonica Thnb. Betula Maximowiczii Regl. Catalpa Kæmpferi S. \& Z. . Cedrela chinensis A. Juss..

$\begin{array}{lll}\text { Cercidiphyll.japonic.S.\&Z. } & 0.0 & 53.0\end{array}$ Hovenia dulcis Thunb.... Morus alba $L . \ldots \ldots \ldots \ldots \ldots \quad \quad 16.0$ Paulownia imperialis $S . \& Z . \quad 0.0$ Rhus succedania $L . \ldots \ldots$.

Sophora japonica L....... Styrax japonica $S$. \& Z. ... Wistaria chinensis de Cand. Zelkowa Keaki Dipp.......

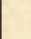

0.0 73.3 $\begin{array}{lllllllllllll}0.0 & 1.3 & 0.3 & 0.0 & 1.5 & 0.5 & 0.0 & & 0.0\end{array}$ 0.0
0.0
0.3
1 $\quad \quad \quad \begin{aligned} & 0.0 \\ & 1.3\end{aligned} \quad \quad \quad \quad \begin{aligned} & 0.0 \\ & 1.5 \\ & 2.5\end{aligned}$ $\begin{array}{lllllllllll}83.0 & 93.0 & 89.1 & 86.0 & 95.0 & 91.2 & 86.0 & 96.0 & 91.7\end{array}$ 3.01014 .5 \begin{tabular}{llllllllllll}
0.0 & 54.0 & 17.8 & 0.0 & 55.0 & 21.6 & 0.0 & 55.0 & 22.8 \\
\hline
\end{tabular}

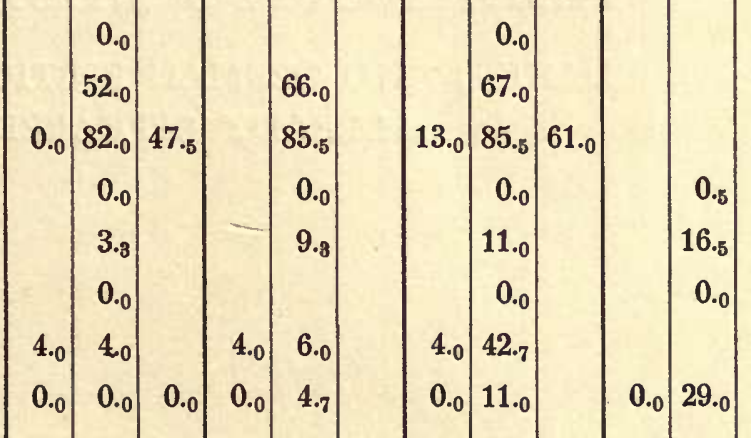
40.0 43. 0 

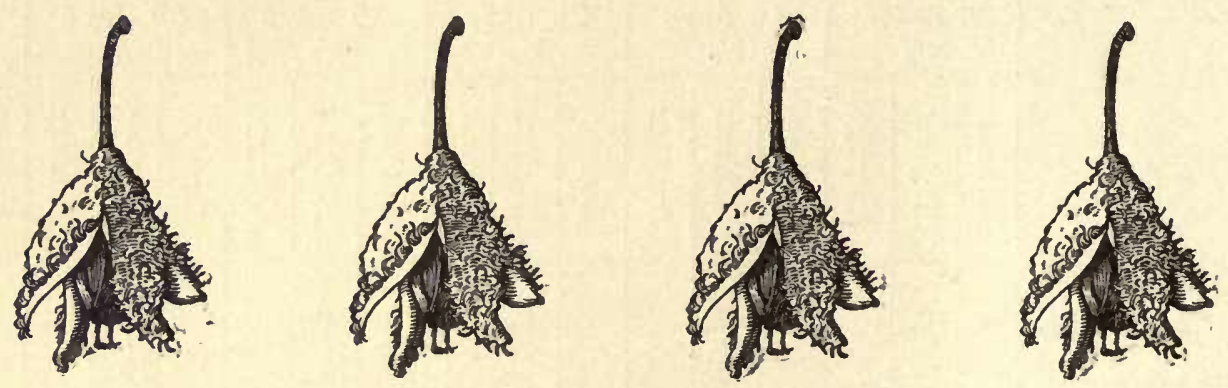

\section{ALL RIGHTS RESERVED \\ DANISH AND GERMAN EDITIONS HAVE ALREADY APPEARED}






$$
\begin{aligned}
& \frac{42251}{5 D}+04 \\
& \frac{P_{3}}{1}
\end{aligned}
$$

UNIVERȘITY OF CALIFORNIA LIBRARY 
